\title{
From the Ground Up: \\ The Alpine and Cross-Country Sportscapes of Gatineau Park, 1910-1967
}

By

Quinn Lanzon

A thesis submitted to the Faculty of Graduate and Postdoctoral Affairs

in partial fulfillment of the requirements for the degree of

\author{
Master of Arts
}

in

History

Carleton University

Ottawa, Ontario

(C) 2014

Quinn Lanzon 


\begin{abstract}
Between 1910 and 1967 the Kingsmere-Camp Fortune area of Gatineau Park evolved from a permeable space of recreational trails and farm roads into two distinct sportscapes produced by the spatial requirements of alpine and cross-country skiing. This thesis examines how people interacted with the recreational landscape through sport, drawing upon Eichberg's 'body culture trialectic' and using the trail network as an experiential archive of sports geography. It describes how the homogeneous ski culture diverged as the meteoric rise in popularity of lift-assisted hill skiing concentrated the development of alpine ski infrastructure at Camp Fortune, creating a modern ski hill and monocultural sportscape there, while leaving the cross country community to develop a network of trails suited to the discipline's unique spatial needs. The thesis concludes that the National Capital Commission should recognize the history of the network of ski trails and hills developed by the Ottawa Ski Club.
\end{abstract}




\section{Acknowledgements}

First of all, I would like to thank Dr. Joanna Dean for being the absolute best supervisor a graduate student could have. At every stage of this project our conversations have helped guide my thinking on the subject, kept me motivated, and made this undertaking a rewarding experience. Thank you Joanna. I would also like to thank Joan White, her encyclopedic knowledge and help have made the completion of this work possible. Thank you to the members of my thesis examining committee: Dr. Shawn Graham, Dr. Jill Wigle, and Dr. Jennifer Evans.

I would also like to thank faculty members who have taken the time to talk with me about my project. Thank you Dr. John Walsh for being a constant source of information, guidance, and an all-around good person. Dr. Graham gets a second mention here for our conversations about Gatineau Park and the Pontiac. My fellow graduate students: Laura Lutes, Michael Chiarello, Erin Gurski, Anna Kuntz, Lina Crompton, Arpita Bajpeyi, Sinead Cox, and Brennan McConnell, among others, are worthy of mention here for teaching me how to be a graduate student and making some great memories both in and outside the department.

The interviewees for this project were kind enough to share their memories of skiing and working in Gatineau Park, and they breathed life into the story I tried to tell. I would like to thank Michael MacConaill, David Midgley, Arnold Midgley, Jamie Rosewarne, Joseph Woods, Martin Aller, and Ann Aller for taking the time to sit down with me and tell their stories. There were also several people who met with me and had unrecorded conversations about the park, notably Marc Cockburn of the Gatineau Valley Historical Society, Marc Dagenais, and Charles Hodgson; extra thanks to Charles Hodgson for his work in digitizing the Ottawa Ski Club Yearbooks.

I am lucky to have amazing friends who supported me throughout this project and joined in some exploration of the park: Mark Taylor, Will Manning Dewar, William Cadham, Nick Anderson, and Oliver Anderson were all essential to the experiential learning that took place on the trails and lodges of Gatineau Park. Engaging discussions with three of my oldest friends, Alex Conlon, Roberto Menezes and Mackenzie Thorne, helped me think about the topic differently, and time spent unwinding with Catherine Vaillant helped ease the torment of an unusually long winter. Bicycles are a huge part of my life, and I would like to thank everyone at Bicyclettes de Hull and Norco Performance Bikes for their ongoing support.

Finally, I would not be anywhere without the unfaltering love and support of my parents and family. First and foremost, I would like to thank my Mom for being there at every step of the way over the past two years and for welcoming friends to the house with unrivaled hospitality. Dad, you continuously push me to excel and strive to improve myself, thank you. Aiden, my older brother, mentor, and best friend, you are the man, thank you for everything. Theodora and Charlotte, my sisters, thank you for always being so positive and supportive. I would also like to thank my aunts, uncles, cousins, and grandparents who encouraged me throughout the project. 


\section{Table of Contents}

$\begin{array}{lr}\text { Abstract } & \text { ii } \\ \text { Acknowledgements } & \text { iii } \\ \text { Table of Contents } & \text { iv } \\ \text { List of Figures } & \text { V }\end{array}$

Introduction 1

Chapter One: The Ottawa Ski Club and the Beginning of Gatineau Park, 1910-1946 21

Chapter Two: Division in Skiing and the Rope Tow Age of Gatineau Park, 1947-1956 59

Chapter Three: Distinct Skiing Communities and the Sportscaping of Gatineau Park, 1957-1967

Conclusion

135

Ethics Clearance Form 146

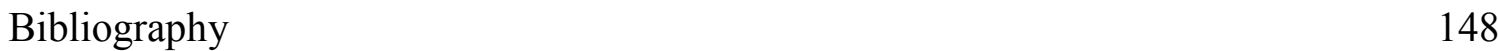




\section{List of Figures}

Figure Description Page

$1 \quad$ Region of the National Capital Existing Conditions Map 21

$2 \quad$ Ottawa Ski Club Flat Trail Map, $1930 \quad 39$

$3 \quad$ Ottawa Ski Club Trail Map, 1931

$4 \quad$ Zoom of 1931 Ottawa Ski Club Trail Map 41

$5 \quad$ Federal District Commission Trail Guide: Kingsmere Section, $1946 \quad 55$

$6 \quad$ Gatineau Bus Advertisement, $1948 \quad 61$

$7 \quad$ Gatineau Park Road and Trail Guide, 1951

$8 \quad$ Photo of Trail Markers on Frank's Trail 93

$9 \quad$ Ottawa Ski Club Trail Map, 1957

10 Camp Fortune Skiing Area of Gatineau Park Orthophoto Map, $1967 \quad 13$ 


\section{Introduction}

On a clear Wednesday night in January, with a few inches of freshly fallen snow blanketing the forest, I made my way to Gatineau Park for a couple hours of crosscountry skiing. Leaving my vehicle at parking lot 7 on Kingsmere Road, I attempted a historically accurate ski route along the cross-country trails near Kingsmere and the hills of the Camp Fortune ski center. My skis were modern and my clothing typical of any recreational trail skier in 2014 , but the route I followed breached a spatial division between alpine hills and cross-country ski trails in Gatineau Park, challenging the area's sports geography.

Skiing from the parking lot along the machine groomed cross-country trail that climbs up to the area's oldest and most trafficked recreational avenue, Ridge Road, I headed towards Camp Fortune on the Skyline Trail, built in 1938, the year Gatineau Park was created. As I neared the summit of the chairlift at Camp Fortune, I took an abandoned section of trail, formerly called Little Switzerland, which led me to the wide alpine runs of the Skyline area at Camp Fortune. On the broad, manicured hills my crosscountry skiing equipment felt inappropriate. The snow at the top of the chairlift was much harder underfoot, even than the groomed surface of Ridge Road. The eerie silence of an immobile chairlift, broken only by the consistent hiss of snow-canons in the distance, and the darkness of hills I was accustomed to seeing illuminated for nightskiing, made the space seem even more strange. Although, standing at the top of the hill, I was only thirty meters from the cross-country trails I was equipped for, I felt that I was transgressing the cultural and aesthetic norms of Gatineau Park space by travelling from cross-country trails into the alpine sportscape. 
My skis were narrow, plastic, and without metal edges. I wore a fleece shirt and vest, lycra pants, and a fanny-pack around my waist carrying water and a snack. Compared to the loose fitting nylon jacket, baggy snow-pants, heavy boots and metal edged skis of my alpine ski equipment, the minimal cross-country outfit made the alpine landscape seem more imposing. As I began skiing the first pitch of the slope, which I had done hundreds of times on alpine skis, I realized that my cross-country equipment and the alpine space I navigated seemed incongruent. Taking my cross-country skis into the alpine ski space demonstrated that the separation of sports spaces in Gatineau Park could be experienced through my body's interaction with the landscape and the constructed ski surfaces. The spatial separation is also socially reinforced, as this same trip, taken on a busy day, raised several eyebrows among the alpine crowd, who easily recognized my cross-country attire and perceived me as out of place. My attempt to ski a historically accurate route that transgressed the bounded spaces of hill and trail skiing in modern Gatineau Park showed that the way my body interacted with the landscape was shaped by the area's sports geography. ${ }^{1}$

This thesis attempts to understand how a specific section of Gatineau Park evolved from a permeable space of recreational trails and farm roads into two distinct spaces produced by alpine and cross-country skiing. I look at how evolution in technologies of ski equipment, growth of competitive racing practices, the emergence of distinct trail and hill ski cultures, improved access by automobile, and the establishment of a modern ski hill shaped how people interacted with the landscape of the Gatineau

\footnotetext{
${ }^{1}$ This experiment was inspired by Annie Gilbert Coleman's introduction in which she intentionally wore outdated equipment while skillfully skiing the slopes of Aspen to emphasize the point that "skiing is about style, spectacle, and status as much as it is about nature, physical experience, and sport." Annie Gilbert Coleman, Ski Style: Sport and Culture in the Rockies (Lawrence: University Press of Kansas, 2004), 1.
} 
Hills as it became home to the largest ski club in the world, the Ottawa Ski Club (OSC), by the late $1950 \mathrm{~s}^{2}{ }^{2}$ The goal is to show that outdoor sports, specifically skiing, are a valuable way of examining how people understood, engaged with, and thought about the Kingsmere-Camp Fortune section of Gatineau Park, and that the trails they built are an experiential archive through which the history of Gatineau Park space can be told. My own intimate knowledge of the landscape is grounded in physical interaction with the Gatineau Hills. I have skied, hiked, run, mountain biked, cycled, and built trails in the Kingsmere-Camp Fortune area for over a decade. The relationship between my body and the landscape through sport and work shapes how I think about space.

The scope of this work is defined as the Kingsmere-Camp Fortune area of the much larger Gatineau Park. Today, Gatineau Park is the National Capital Region's largest park, encompassing 361 square kilometers of hills and lakes just north of Ottawa, in the Outaouais region of Quebec. The National Capital Commission (NCC), a federally operated body, manages the wilderness conservation area and its recreational infrastructure. The park currently offers a system of multi-use, multi-season recreational trails, public beaches, and seasonal camping areas to both local patrons and visiting tourists. Its proximity to the large populations of Ottawa and Gatineau combined with easy accessibility by automobile, via parkways and two provincial highways, have made the park a popular recreational area for local residents; there are also permanent residents and cottagers who own private tracts of land throughout the park. The park, which is located in the francophone province of Quebec, is governed by the NCC, a federal body, making Gatineau Park the only federally protected conservation area that does not have

2 George McHugh, "Presidential Comment," Ottawa Ski Club Yearbook 1958-59 (Ottawa: Ottawa Ski Club Publication), 13. http://gvhs.ca/digital/gatineau-park/osc/1958-1959-year-book.pdf (accessed 3 March 2014). 
National Park status. Although the unique political context is essential to thinking about Gatineau Park as an entity, language and government regulation are not central to this study of recreational space in the Gatineau Hills.

In winter, Gatineau Park offers over 200 kilometers of cross-country ski trails. Over 100 kilometers are machine groomed to accommodate classic, skate, and backcountry skiers. ${ }^{3}$ The NCC maintains the trails, and skiers are expected to purchase day tickets or season's passes. There is an alpine ski hill in the heart of Gatineau Park, at Camp Fortune, offering skiing seven days a week, night skiing six days a week, equipment rental, four chairlifts, and hills for beginners and experts. Operators at Camp Fortune own the buildings and infrastructure, but lease the land from the NCC. Skiers purchase tickets and passes directly from the operators at Camp Fortune. The hills around Camp Fortune attracted skiers as early as the First World War.

There is a dearth of literature on Gatineau Park, and what does exist generally understates the influence of skiers in the evolution of the landscape, concentrating instead on their political influence in forest conservation. Alisa Apostle's MA thesis, "The View From the Hill: National Park Culture and Gatineau Park 1920-1960" (1997), explores the history of Gatineau Park in the context of forest preservation, the development of the National Capital Region, and national parks. Her work is rooted in Federal District Commission (FDC) records, correspondence with the Federal Woodlands Preservation League, and newspaper articles from the Ottawa Citizen. This thesis builds on Apostle's work by looking at how the FDC and OSC shaped recreational space in the KingsmereCamp Fortune area following the commission's initial land purchases and appropriations.

\footnotetext{
${ }^{3}$ National Capital Commission, "Cross-Country Skiing in Gatineau Park," NCC website. http://www.nccccn.gc.ca/places-to-visit/gatineau-park/things-to-do/cross-country-skiing-gatineau-park (accessed 26 February 2014).
} 
Katherine Fletcher's Historical Walks: The Gatineau Park Story offers a comprehensive human and natural history of Gatineau Park. Originally published in 1998, with a third edition printed in 2004, the first part of her work surveys the history of the entire park from the early $17^{\text {th }}$ century until the present day. Fletcher's book is a collection of stories of the industries, families, events, and myths that shaped the area's human history. Her work touches on a wide range of topics, and is very helpful in understanding the chronology of the park. Later works on the history of the park cite the 1998 edition as an authority on Gatineau Park.

In 2004 the NCC funded a "Study on the influence of local interest groups and the sociopolitical context of the Park's creation from 1903 to 1956" by Serge Gagnon and Michele Filion, published as The Creation and Early Development of Gatineau Park. ${ }^{4}$ Gagnon and Filion pointed out the social and political influence of the OSC in the creation of the park. They argue that the club's land purchases in the Gatineau Hills and the establishment of the Ottawa Ski Club Forest Preservation Society, in 1933, allowed the idea of a park in the hills to emerge and gradually gain federal support. ${ }^{5}$ Citing Fletcher, they argue that the OSC's Forest Preservation Society was the impetus for the creation of the Federal Woodlands Preservation League, and the league is credited with pressuring the federal government and FDC into finally setting aside lands for Gatineau Park in $1938 .{ }^{6}$ These histories emphasize the political entity of Gatineau Park. This thesis

\footnotetext{
${ }^{4}$ Michele Filion and Serge Gagnon, The Creation and Early Development of Gatineau Park (NCC: Ottawa, 2004), 1.

5 Filion and Gagnon, The Creation and Early Development of Gatineau Park, 14. The Ottawa Ski Club News published a column promoting the Forest Preservation Society. "Ottawa Ski Club News No. 1," (December 1, 1933). http://gvhs.ca/digital/gatineau-park/osc/1933-12-01.pdf (accessed 4 March, 2014). ${ }^{6}$ Dennis Messier, The Gatineau Park Chronicle 2007, National Capital Commission, 2007, accessed via http://gvhs.ca/digital/gatineau-park/chronicles/GatineauParkChronicle 2007.pdf (accessed 27 February 2014).
} 
incorporates the ski trails and hills built by the OSC in the Kingsmere-Camp Fortune area into the conversation.

Dennis Messier's Gatineau Park Chronicle, a short newsletter produced by the NCC in 2007, describes the creation of Gatineau Park emphasizing the political organizations that led to the first land purchases in the Gatineau Hills by the FDC. Messier points out the role of OSC president Charles Mortureux in the movement towards forest protection that eventually led to the creation of the park, but skiers' role in shaping the landscape is largely omitted. ${ }^{7}$ In 2009, a second Gatineau Park Chronicle combined short articles by Messier, Carol Martin, Shawn Graham, and Fabian Mugny, delving into the hills' industrial history by looking at the logging, milling, mining, farming, and acid condensation industries that existed in the area. ${ }^{8}$ The importance of the hills as a recreational space for skiers, and the large skiing community that emerged in the area are understated by these more recent histories.

Today, the NCC's official website presents a history of the park entirely bereft of skiers: the discussion of human interaction with the Gatineau Hills in the twentieth century mentions only "a growing number of outdoor enthusiasts," disregarding the considerable work done by the OSC. The brief history presented by the NCC reflects the commission's current policy, which appears to want to limit human interaction with Gatineau Park land; the NCC describes their policy as one of "gradual movement towards

\footnotetext{
7 Dennis Messier, The Gatineau Park Chronicle 2007, National Capital Commission, 2007, accessed via http://gvhs.ca/digital/gatineau-park/chronicles/GatineauParkChronicle_2007.pdf (accessed 27 February 2014).

8 Dennis Messier, Carol Martin, Shawn Graham, and Fabian Mugny, The Gatineau Park Chronicle 2009, National Capital Commission, 2009, http://gvhs.ca/digital/gatineaupark/chronicles/GatineauParkChronicle_2009.pdf (accessed 27 February 2014).
} 
environmental-protection." ${ }^{\prime 9}$ The NCC's current policy and the brief history presented to the public on their website ignores the multiple ways in which skiing and the OSC shaped Gatineau Park space.

Herbert Marshall published The History of the Ottawa Ski Club in 1972. The most complete history of the club, it is grounded in Marshall's recollections as former president of the OSC and long time honorary member, and frequently incorporates text from the OSC's archive of newsletters, bulletins, and yearbooks. Marshall's History, though not an academic work, was helpful in situating the chronological evolution of trail construction, lodge acquisition, and growth of the OSC. ${ }^{10}$ Charles Hodgson of the Gatineau Valley Historical Society (GVHS) wrote a condensed history of the OSC gleaned from a digitization project that made all of the club's publications available online via the GVHS website (www.gvhs.ca). Hodgson's brief history synthesized the club's transition from jumping in Rockliffe Park, in 1910, to the development of Camp Fortune, and the club's eventual bankruptcy in the 1980s, while pointing out the humour and sarcasm on the pages of OSC publications. ${ }^{11}$ The two histories helped guide the chronology of this work, and situate developments of the OSC within the larger context of Gatineau Park's development.

The complete collection of OSC publications, spanning from 1921 until 1967, form the spine of primary sources for this work on skiing in the Gatineau Hills. OSC members were the first skiers to use the area for skiing, build ski trails, and purchase land

\footnotetext{
${ }^{9}$ NCC, "History of the Park," NCC website. http://www.ncc-ccn.gc.ca/places-to-visit/gatineau-park/thingsto-do/cross-country-skiing-gatineau-park (accessed 26 February 2014).

10 Herbert Marshall, The History of the Ottawa Ski Club (Ottawa: ns, 1972).

11 Charles Hodgson, "Charles Hodgson's Version of The History of the Ottawa Ski Club," Gatineau Valley Historical Society, http://gvhs.ca/digital/gatineau-park/osc/index.html (accessed 27 February 2014). Charles Hodgson's work in digitizing the OSC publications was invaluable to my research, it allowed me to access the sources immediately and has greatly enriched the skier's perspective in this thesis.
} 
and buildings for the purpose of recreational skiing, and they produced a massive archive of newsletters, bulletins, and yearbooks. The club grew to be the largest in the world, with over 10,000 members in 1960, and the spatial requirements of their ski infrastructure created two distinct recreational landscapes within the Kingsmere-Camp Fortune area. ${ }^{12}$ All of the yearbooks in the postwar period were examined and used in conjunction with Marshall and Hodgson's histories to provide skiers' perspectives on the evolution of Gatineau Hills' space.

Most OSC publications between 1921 and 1945 were also examined, but here the records pertaining to the creation of Gatineau Park, the FDC, Federal Woodlands Preservation League, and William Lyon Mackenzie King's diaries are used to situate the evolution of ski space within the context of federal plans to improve the National Capital Region. ${ }^{13}$ This work attempts to integrate skiers and the OSC's trail network into the conversation as the creation of Gatineau Park brought the FDC and federal resources into the Kingsmere-Camp Fortune area, and the commission became more present as they and the OSC worked together to promote recreation in the area.

The ski diaries of Harmon Cahill, a distinguished member of the OSC, and devout trail skier, were also used for this work. His diaries recorded his ski trips from January 1955 until April 1968. Cahill's journal contained distances, trail names, starting points, and end points for every trip; these records helped reconstruct how trail skiers moved

\footnotetext{
12 George McHugh, “The President's Message,” Ottawa Ski Club Yearbook 1960-61 (Ottawa: Ottawa Ski Club Publication, 1961), 9. http://gvhs.ca/digital/gatineau-park/osc/1960-1961-year-book.pdf (accessed 4 March 2014).

13 I build uponApostle's work on the creation of Gatineau Park and enter the conversation by looking more closely at the relationship between the OSC, FDC, and the Gatineau Hills as a recreational space.
} 
through the network in this period. ${ }^{14}$ Cahill's name frequently appeared in OSC publications, and he was well known by trail skiers interviewed for this thesis.

Oral interviews are another significant archive for this thesis. Interviewees were selected using the snowball method, as one interviewee suggested others, and some were found through my own connections in the local ski community. ${ }^{15}$ The sample of six skiers included members of both the alpine and cross-country communities, from different eras. They were all keen skiers and important members of their respective communities. Brothers Arnold and David Midgley began skiing in the Gatineau Hills in the mid-1940s. They were both alpine skiers, competitive racers, and volunteer members of the Night Riders trail maintenance group. The Midgleys both went on to pursue professional careers in the ski industry. Arnold, born in 1935, was an electrical engineer, developing snowmaking equipment: he was also a jury member at the Olympic Winter Games with the FIS International Ski Federation, and was elected chair of the Canadian Ski Museum in 2002. David, six years older than Arnold, was a long serving member and Captain of the Night Riders, and he worked for many years alongside John Clifford and the OSC as they developed the alpine infrastructure at Camp Fortune. David worked developing ski resorts in Canada and New Zealand over the course of his career. Michael MacConaill began skiing in Gatineau Park in 1956 after moving to Canada from Cork, Ireland. A professor of pharmacology at the University of Ottawa, MacConaill quickly integrated himself into the trail skiing community and their volunteer corps, the Trail Riders. Martin "Mo" Aller is a retired pilot of the Royal Canadian Air Force: he and his

\footnotetext{
14 Harmon Cahill's diaries were lent to me by his grandson Mark Dagenais.

15 I work at a bike shop that sells cross-country skis during the winter. I met Bryan Aller when he delivered a product knowledge seminar for Fischer Skis and Swix wax, and he suggested I speak with his parents Ann and Martin. Joseph Woods was the first person I interviewed; he was referred to me by his son Matthew Woods. Joseph put me in contact with Arnold Midgley and Michael MacConaill.
} 
wife Ann moved to Ottawa in 1962 following Martin's posting there. Martin was a competitive cross-country ski racer, and won the 1972 Canadian Ski Marathon. The Allers' skied with their sons David and Bryan. Joseph Woods also began skiing in the park in the 1960s, and he was the first full-time employee hired by the OSC to maintain the trail network in 1968. Finally, Jamie Rosewarne was the general manager of Camp Fortune from 1976 until 1990, and his reflections help situate the legacy of skiing in Ottawa in a national context.

The interviewees in this project told the stories of their youth and adult days spent skiing the Gatineau Hills, and years of volunteer and professional work there. The Allers told stories of bringing up a family on the cross-country trails. The Midgleys and MacConaill, members of volunteer maintenance corps, the Trail Riders and Night Riders, recalled not only the names of trails and hills, but told the stories of their construction. Their memories of the hills were stirred by looking at maps from different eras: the lines on the maps were more than just a way of moving through space, they were places where a relationship with the park rooted in the ground came to be. ${ }^{16}$ These interviews were open ended, and conversations with interviewees extended beyond our formal recordings if clarification was needed. There are limitations to the sample of interviewees used here. Because they were all very involved in the ski community, and some went on to pursue careers in the ski industry, it is possible that interviewees idealized the years of their youth spent skiing and working in the Gatineau Hills. Although they all shared a strong

\footnotetext{
16 David and Arnold Midgley were both Night Riders, and David worked for John Clifford at Camp Fortune in the 1950s and 1960s. Michael MacConaill was a member of the Trail Riders from 1957 until the late 1960s, and Joseph Woods was a Trail Rider, and the first full time person employed by the NCC to maintain the cross-country trails, as of 1968.
} 
bond with the Gatineau Park landscape through skiing, interviewees' relationships with space were all different, rooted in their personal experiences.

The Midgleys skied in the area from a time when skiers "all started as trail skiers," before rope tows allowed the discipline of alpine skiing to flourish on the slopes of Camp Fortune. As David Midgley recalled, they "lived through the whole evolvement [sic] of skiing," and watched the growth of the sport transform the landscape. ${ }^{17}$ For the Midgleys, MacConaill, and Woods, Gatineau Park was a space of work and play. They remembered the feeling of skiing a certain section of trail, recalled specific moments of work, and explained the transformation of the landscape as a result of changes in technology and accessibility, as well as recreation.

For Ann and Martin Aller, a husband and wife who brought their children on demanding weekend cross-country ski trips on the trails, stories of Gatineau Park arose from memories of struggle against the cold and the hills as a family, and how they built lifelong bonds with a handful of other skiing families on the trail network. A basement room lined with race memorabilia and dozens of retired pairs of skis catalogued the memories of a proud father and demonstrated the important role ski racing played in the Aller family. Surrounded by medals, photographs, and racing bibs, a different story of skiing was told than in the well-lit living room with a map sprawled on the coffee table. ${ }^{18}$

The interviews in this thesis serve as "a tool to document an interviewee's account of his or her experience in a given setting at a given time." ${ }^{19}$ The Handbook of Oral History notes that these types of interviews can be treated as primary texts, and

\footnotetext{
17 David Midgley, interview by the author, November 15, 2013, Gatineau, QC, digital recording. 18 Martin Aller and Ann Aller, interview by author, November 16, 2013, Ottawa, ON, digital recording. 19 Alice M. Hoffman and Howard S. Hoffman, "Memory and Theory: Personal and Social," Handbook of Oral History, eds. Thomas L. Charlton, Lois E. Myers, and Rebecca Sharpless (Oxford: AltaMira Press, 2006), 294.
} 
adapted to analysis in the same way. The stories of the men and women interviewed are situated in the existing histories of the OSC and Gatineau Park, as well as the primary sources of Harmon Cahill's diary, OSC maps, and OSC publications. The spaces of their stories were the trails, hills, lodges, and parking lots of the Gatineau Hills.

Maps are instrumental to the study of space, and for this work, OSC, FDC, and NCC maps act as a visual tool to show the changing geography of recreation through the trail network. For skiers, the maps guided them through the hills and helped create a vernacular unique to Gatineau Park. Maps inscribed the area with names and symbols that allowed skiers to read the landscape and refer to specific places on the trail network using colloquial names. ${ }^{20}$ As maps, names, and recreational space became more established in Gatineau Park, and skiing acquired new styles and equipment, the skiing community became divided according to the spatial needs unique to hill and trail skiers. The rise of hill skiing, development of rope tows, and expansion of the trail network reconfigured space and how people moved through the hills.

The history of Gatineau Park has not received the same attention as Canada's other national parks. When dealing with skiers' and cottagers' early movement into the Gatineau Hills for leisure, recreation, and the eventual creation of the park, this work looks to literature on other North American national parks, and the wilderness conservation movements in the United States in the twentieth century, especially in the northeastern states. Ellen Stroud explored the intertwined relationship of cities, people, industry, and the forests of Maine, New Hampshire, and New York, where "[m]any of the new trees are small, and most of the new forests are fractured. Roads wind among the

\footnotetext{
20 John Pickles, A History of Spaces: Cartographic reason, mapping, and the geo-coded world (London and New York: Routledge, 2004), 56.
} 
trees, houses are scattered through the groves, and ski trails are carved into forested hills." ${ }^{21}$ Stroud's work shows protected forests of today, perceived as bereft of human interaction, to be the result of an urban population who sought leisure in nature and took steps to protect forests for their aesthetic value. Stroud's work helped situate the transition towards Gatineau Park and place its early years in the wider North American wilderness movement, where issues of balancing recreation with preservation presented themselves. $^{22}$

When dealing with people and their relationship with Gatineau Park space, this work follows Matthew Klingle's argument that “paying attention to space allows historians to study how the stage for consumption has been altered, the set rearranged, and how the actors moved across it and altered the script." 23 Klingle argued that environmental histories should incorporate both the political and cultural boundaries of geography, and the "physical interactions" between animals, humans, and plants in the study of delimited spaces. Klingle encouraged the integration of ecology into environmental histories through consideration of the physical relationship humans created with forests, lakes, and topography. In the Gatineau Hills, generations of skiers did this by building trails and clearing hills as they transformed the landscape to suit the needs of an evolving sport.

Richard White's emphasis on work as a valuable point of study for the connection between humans and nature helps guide the discussion of how the embodied relationship

\footnotetext{
21 Ellen Stroud, Nature Next Door: Cities and Trees in the American Northeast (Seattle: University of Washington Press, 2012), 147.

22 Claire Campbell, A Century of Park Canada, 1911-2011 (Calgary: Univeristy of Calgary Press, 2011); Michael J. Yochim, "Snow Machines in the Garden: The History of Snowmobiles in Glacier and Yellowstone National Parks," The Magazine of Western History, Vol. 3, No. 53 (2003), p. 13. ${ }^{23}$ Matthew W. Klingle, "Spaces of Consumption in Environmental History," History and Theory, Vol. 42, No. 4 (December 2003), 99.
} 
of the men who built trails and developed ski infrastructure shaped Gatineau Park space. By working in nature, men came to know nature more intimately than most. Following White, attention is paid to the volunteers who acquired intimate knowledge of the landscape through their work. They hiked and brushed trails in late autumn, when fallen leaves and dried underbrush provided a less obstructed view of the area and allowed them to better understand the spatial restrictions posed by the rocky terrain of the Canadian Shield. The earliest volunteer labour corps, the Night Riders of the Canyon, often viewed the snow-covered hills by moonlight, when reflections off the snow illuminate the curvature of the slopes better than the sunlight. ${ }^{24}$ The needs of skiers and the physical limitations of three-dimensional space determined which patches of ground became trails and which did not. Trails harnessed the gravitational energy of the hills' topography to satisfy the physical needs of the ski community. ${ }^{25}$

Academic histories of skiing and ski culture have primarily taken the large mountain ranges of Colorado's Rockies and the European Alps as a geographical area of study. These works explore concepts of resort culture, private land-ownership issues, wilderness protection, tourism, upper class recreation, gender, "whiteness," and "Aspenization." ${ }^{26}$ Annie Gilbert Coleman's Ski Style: Sport and Culture in the Rockies

\footnotetext{
24 In our interview, Joseph Woods encouraged me to ski by moonlight because the forest looked different when seen in the light of the moon, arguing the curvature of the terrain was especially clear. After skiing at under the moon, on the $11,8,17,6,22,34$, and 30, trails I had skied in daylight many times, I saw that he was right. Subtle hills and bumps in terrain are clearer at night.

25 Richard White, The Organic Machine: The Remaking of the Columbia River (New York: Hill and Wang, 1995), 4; Richard White, “'Are you and Environmentalist or do you Work for a Living?': Work and Nature," in Uncommon Ground, ed. William Cronon, 171-185 (New York: W.W. Norton \& Company, 1995).

${ }^{26}$ For works on ski culture and tourism in the Rocky Mountains and the Alps see Michael W. Childers, Colorado Powder Keg: Ski Resorts and the Environmental Movement (Lawrence: University Press of Kansas, 2012); Coleman, Ski Style; Annie Gilbert Coleman, "The Unbearable Whiteness of Skiing" Pacific Historical Review, Vol. 65, No. 4, Tourism and the American West (Nov., 1996), pp. 583-614; Andrew Denning, "From Sublime Landscapes to "White Gold": How Skiing Transformed the Alps after 1930,"
} 
(2004) tackled the history of skiing in Colorado. Coleman explored the tension between rural communities and wealthy investors who sought to profit from ski resort development; her work was grounded in oral interviews and the changing culture of skiing, with an emphasis on class, style, and performance on the ski slopes. ${ }^{27}$ Topics like the Arlberg ski school, chairlift developments, and snowmaking are addressed from beyond the Forest Service's records and visions of rich investors; they are explored on the slopes and in the streets of resort towns. Questions of performativity, physicality, competition, and consumption are explained through the memories of local residents, former ski bums, and Coleman's own experience on the slopes of Aspen. The spaces of Ski Style are expensive resort towns and rural communities, the slopes of challenging hills, and the star-studded sidewalks of Aspen. Coleman's approach has influenced this work a great deal. Her attention to sport and the spaces where skiers perform their perceived role in a sports landscape helped this work imagine the trails and hills of the Kingsmere-Camp Fortune area and integrate the voices of skiers into the text. Unlike Coleman's Aspen, though, conflicts of ski culture in Gatineau Park were the result of divergent sports interests, not different levels of consumerism; skiers' relationships to the spaces of Gatineau Park were grounded in topography, gravity, and work.

\footnotetext{
Environmental History (2014) 19 (1): 78-108; Duke Richey, "The Aspenization of Telluride: Coming of Age and Mythologizing Change in Ski Country, 1945-1985." Pacific Historical Review Vol. 79, No. 2 (May 2010) (pp. 231-264); Hal Rothman, Devil's Bargains: Tourism in the Twentieth Century American West (Lawrence: University Press of Kansas, 1998); Hal Rothman, " 'Powder Aplenty for Native and Guest Alike': Steamboat Springs, Corporate Control, and the Changing Meaning of Home," Montana: The Magazine of Western History, Vol. 48, No. 4 (Winter, 1998), pp. 2-17. For works on skiing outside the Rocky Mountains and Alps see John B. Allen, "The Modernization of the Skisport: Ishpeming's Contribution to American Skiing," Michigan Historical Review, Vol. 16, No. 1 (Spring, 1990), pp. 1-20. 27 Coleman, Ski Style, 2004. For ski resort culture, see also Duke Richey, "The Aspenization of Telluride: Coming of Age and Mythologizing Change in Ski Country, 1945-1985." Pacific Historical Review Vol. 79, No. 2 (May 2010), 231-264; and Rothman, Devil's Bargains.
} 
In 2012, sociologist Marc Stoddart's study of skiing in British Columbia reached similar conclusions to Coleman's study of Rocky Mountain skiing. But Stoddart conceded that his findings "may be less applicable to eastern North America." 28 Stoddart recognized that studies grounded in the mountainous topography of the Alps and Colorado, emblematic areas of the ski industry, produced a different ski experience from the lower hills in the east. Despite this, Stoddart's work is important to this study because he pays attention to the relationship between mountain, ski surface, equipment, and skier. He argues, like Coleman, that ski resort culture differs greatly from one resort to another, based on the local geography and the motivation of operators, but in a Canadian context. $^{29}$

Michael Childers' Colorado Powder Keg: Ski Resorts and the Environmental Movement (2012) explores the struggle between ski hill operators, resort developers, and the U.S. Forest Service to balance profitable recreation with environmental protection. Growing demand for hill skiing facilities and resorts, very expensive to build and maintain, forced the Forest Service to relinquish control of protected lands because it could not afford to supply adequate facilities. Private operators purchased tracts of land in the Rockies and undertook massive resort development programs. A similar relationship between the FDC, OSC, and John Clifford Lifts, contracted by the OSC to build alpine infrastructure, shaped the development of recreation in Gatineau Park.

The evolution of skiing in the Gatineau Hills was different from that of Colorado, however, because the comparatively small tract of land had been settled, farmed, and skied long before the FDC began expropriating land for Gatineau Park. The Forest

\footnotetext{
28 Mark C. Stoddart, Making Meaning out of Mountains: The Political Ecology of Skiing (Vancouver: UBC Press, 2012), 6.

${ }^{29}$ Stoddart, Making Meaning out of Mountains, 11.
} 
Service's control and protection of land in the Colorado Mountains complicated the creation of ski hills there by adding a layer of government between developers and the hills. The situation in the Gatineau Hills was different because skiers owned the land and began developing ski infrastructure prior to the FDC's expropriations. ${ }^{30}$ Childers' work gives an insightful perspective on the managerial difficulties associated with developing skiing in protected areas, which was the norm in the Rocky Mountains, but skiers' relationship with Rocky Mountain landscape is eclipsed in Childers' book by the struggle for ownership. This thesis places more emphasis on the interaction between people and the landscape through skiing.

Andrew Denning recently explored the relationship between skiing and the Alps in the age of mechanical lift access and manicured ski runs. He focuses on landscape change and describes how, especially during the postwar rise in skiing's popularity, the needs of skiers transformed the Alps. "Where a given Alpine landscape once accommodated diverse activities such as skiing, hiking, hunting, nature appreciation, and preservation, the needs of Alpine skiers for cleared slopes and groomed snow eliminated the possibility for multiple uses, and the tourism interests that depended on the business of Alpine skiers progressively established monocultural sporting landscapes in the Alps." ${ }^{\prime 31}$ Denning argues that despite the tremendous work done to shape the mountains to suit the needs of skiers, the sport still relied on weather and the topography of the mountains; snowmaking, chairlifts, and resorts only made skiing less dependent on nature, not independent. Denning's use of geographer John Bale's concept of a

\footnotetext{
30 In 1938, the first year of Gatineau Park's existence, the FDC improved recreational infrastructure, adding the Skyline Trail to the network, improving parking lots, and eventually offering snow removal services.

${ }^{31}$ Denning, "From Sublime Landscapes to 'White Gold," 85.
} 
"monocultural sportscape" to explain the increasingly controlled surfaces at Alpine resorts inspired the theoretical framework applied throughout this thesis to explain the relationship between skiers and the Kingsmere-Camp Fortune area. ${ }^{32}$

In the introduction to the second edition of Sports Geography, John Bale outlined one of the aspects explored by sports geography as "the changing character of the sports landscape and the symbiosis between the sports environment and those who participate in it. ${ }^{\prime 33}$ This thesis continuously attempts to show how changing sports practices affected the landscape of the Gatineau Hills, and chapter 2 includes an in-depth explanation of Bale's understanding of the relationship between sport and geography, which is applied to the Kingsmere-Camp Fortune area following the postwar ski boom. Bale's work uses a 'trialectic of sport' to explain the relationship between sports communities and geography. This thesis uses Bale to show spatial division and evolution of the Kingsmere-Camp Fortune area as the product of the spatial requirements of skiing. Bale's "trialectic" was inspired by the work of German sociologist Henning Eichberg. Bale edited a compilation of Eichberg's essays on sport, space, and identity in 1998, before writing Sports Geography, and Eichberg's 'body culture trialectic,' especially, is present in his work. The "trialectic" describes three general types of sports communities and outlines how each interacts with space and technology: the "trialectic" is explained in depth in chapter 2. Eichberg argues that "seeking the ways in which bodies and landscapes are configured is a means of recognizing diversity in what is often thought to be an increasingly homogenous world." ${ }^{34}$ This thesis first uses Eichberg's

\footnotetext{
32 John Bale, Sports Geography, $2^{\text {nd }}$ ed (London: Routledge, 2003), 31.

33 John Bale, Sports Geography, 5.

34 Henning Eichberg, Body Cultures: Essays on Sport, Space, and Identity, eds. John Bale and Chris Philo (London: Routledge, 1998), 8.
} 
"trialectic" to situate the different body cultures of skiing in the Gatineau Hills, before looking to Bale's adaptation. Bale and Eichberg's emphasis on the relationship between the body and the landscape through sport is fundamental to chapter 2 and 3 in this work.

This work intends to tell the story of how a group of skiers from Ottawa created the recreational trail network in the Kingsmere-Camp Fortune area of the Gatineau Hills that precipitated the creation of Gatineau Park and remains the frame of its recreational landscape. The physical features of the hills, evolution of ski technology and technique, and the growth of the local skiing community combined to permanently alter the landscape to suit the needs of skiers. From the Ottawa Ski Club's purchase of Camp Fortune in 1920 to their printing of the 1967 orthophoto map that depicted every trail built in Gatineau Park to that point, it was the recreational needs of leisure skiers, the competitive drive of racers, and the work of trail builders that shaped Gatineau Park as a recreational space from the ground up.

Chapter 1 introduces the geography of the Ottawa Valley, and describes how a recreational sports club of civil servants from Ottawa traveled into the Gatineau Hills in search of physical fitness. This period saw the mobilization of influential residents and cottagers to protect the forests, and witnessed the first land expropriations by the FDC for the creation of Gatineau Park. This chapter situates these events in a larger wilderness recreation and conservation movement in North America. In chapter 2, the landscape becomes mechanized following the Second World War, as rope tows became more popular. Mechanical assistance on climbs allowed skiers to concentrate their efforts on downhill skiing and the club transformed the landscape to better suit the changing needs of postwar alpine skiers. The mechanization of Camp Fortune began dividing the 
membership of the OSC between trail and hill skiers. Chapter 3 explores the massive growth in OSC membership in the late 1950s that made it the largest club of its kind in the world. This period saw a resurgence of trail skiing and a more definitive separation between the sports societies of hill and trail skiers on social, cultural, and technological levels. Throughout this study, the physical relationship between skiers and the landscape is emphasized in order to tell the story of how recreational use of the Kingsmere-Camp Fortune area organized Gatineau Park space from the ground up. 


\section{Chapter One: The Ottawa Ski Club and the Beginning of Gatineau Park, 1910-1946}

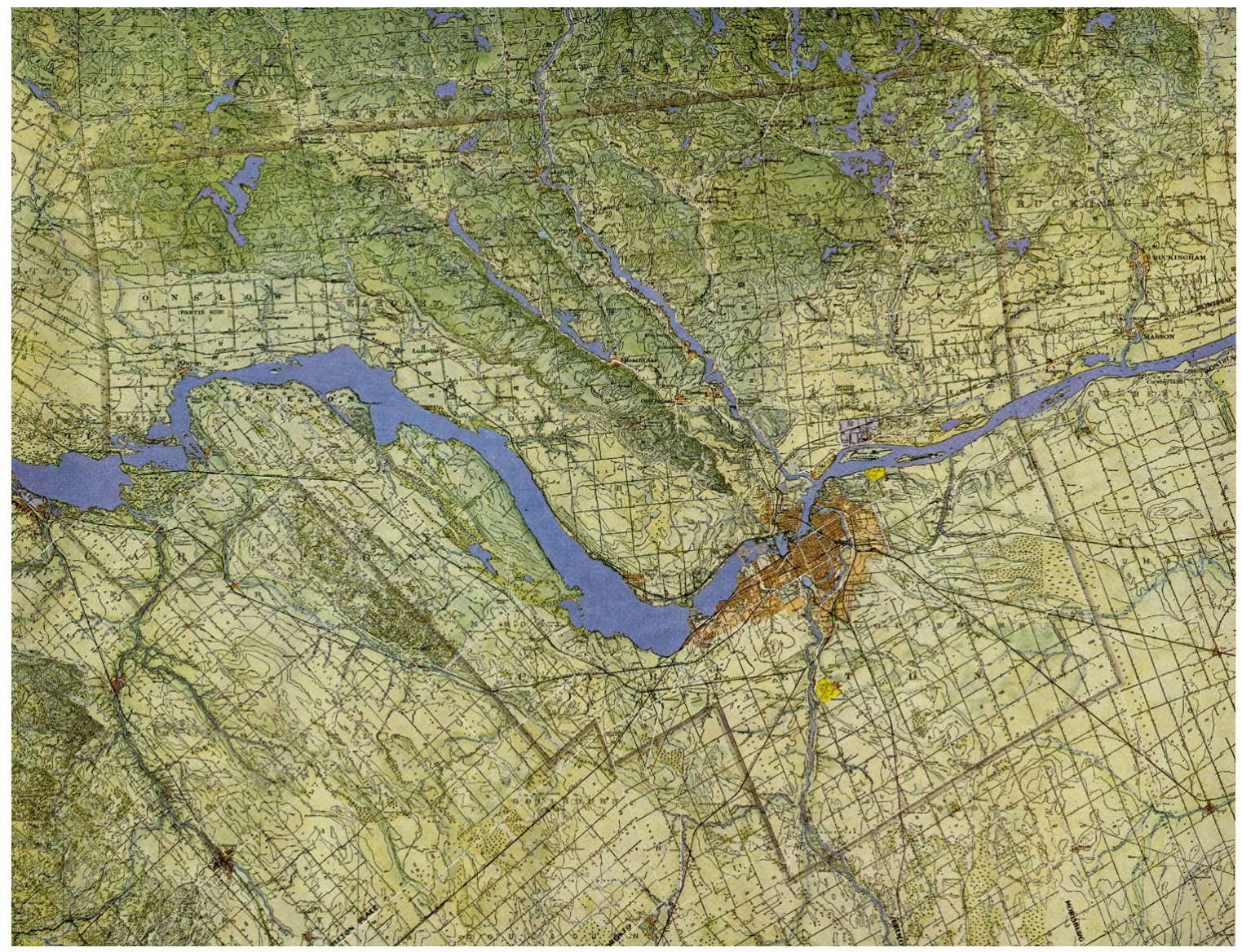

Figure 1: Region of the National Capital Existing Conditions Map, Greber Report, 1950, Plate 4, Atlas.

Over one billion years ago, a major shift of the earth's crust caused the

continental crunch: as two tectonic plates collided, volcanoes and tall mountains rose from the earth along the fault line. These mountains were the basis of today's Gatineau Hills. Over millions of years, the mountains eroded, sand and lime mud gradually flowed to the bottom of a tropical sea at the foot of the mountains, leaving mostly hard granites, marbles, and quartzites in the elevated land. Another shift in the earth's crust along the same fault line, this time a depression and not a crunch, created the Ottawa-Bonnechere Graben, a low-lying area that now contains the Ottawa River valley. On the north side, 
the Ottawa River hugs the sharp northern edge of the Graben, now the Eardley

Escarpment. During the Wisconsin Glaciation, the Laurentide Ice Sheet scraped soil from the ancient mountains, leaving pockets of gravel and sand, and as the ice retreated the Champlain Sea laid down a rich bed of marine clay in much of the lowlying area. ${ }^{35}$

Today, the Ottawa, Gatineau, and Rideau Rivers converge where the Champlain Sea formerly existed. The Gatineau, a powerful tributary with nine sets of rapids, flows down from the Baskatong Reservoir to the north and west in Quebec before pouring into the Ottawa River. Flowing down from the Lower Rideau Lake in Ontario, the Rideau River also meets the southern bank of the Ottawa at this point. The three rivers meet due east of the bridges linking the Quebec town of Hull, with Ottawa, Ontario, on the southern shore. To the west of the confluence, the Ottawa River swings down and around a ninety-degree turn towards the northwest to skirt around the natural barrier of the Eardley Escarpment.

The Ottawa Valley's rich natural environment has supported diverse and thriving animal populations for millennia. A major junction of rivers coming from the north, south, and west; fertile lands extending south of the escarpment; and towering conifer forests in the Gatineau Hills made the area equally attractive to humans. The rivers served as important arteries of trade and the Ottawa Valley was the heartland of Algonkin controlled territory extending to the west and north when Samuel de Champlain recorded his travels through the region in $1613 .{ }^{36}$ In 1800 , Philemon Wright established a small settlement, Wrightville, on the north bank of the Ottawa River, near the Chaudière Falls.

\footnotetext{
35 "The Champlain Sea," Hooper Virtual Natural History Museum, http://hoopermuseum.earthsci.carleton.ca/2001_champlain2_mb/ (accessed 25 February 2014).

36 Peter Hessel, The Algonkin Nation: The Original People of the Ottawa Valley (Arnprior: Kichesippi Books, 1993), 9-10; Katherine Fletcher, Historical Walks: The Gatineau Park Story, $3^{\text {rd }}$ edition (Markham: Fitzhenry \& Whiteside Limited, 2004), 4.
} 
Wright brought his family, and was accompanied by five other families, twenty-five labourers, and several draft animals; he came with the intent of farming the fertile soil he had prospected over the previous four years, but the timber trade proved more lucrative. In 1806, Wright successfully floated a barge of squared timber down the Ottawa River to Quebec City, where it was then shipped overseas. ${ }^{37}$ Foreign demand for timber, the rich forest resources of the Gatineau Hills lining the Gatineau River, and close rivers for easy export quickly transformed the Gatineau Valley into the most important lumber industry in North America in the nineteenth century. The economic opportunity of logging attracted more people to the region. In winter, logging camps were set up in the forests that lined the shores of the Gatineau River, and in summer, logs and timber floated downstream for export. Industrial logging moved northward along the Gatineau as forests became depleted, and by the late nineteenth century logging in the southern Gatineau Hills was conducted mainly by local farmers who required coniferous trees for timberframed buildings and deciduous hardwoods for heating.

Farming communities replaced logging camps along fertile river valleys and in pockets in the hills where the Champlain Sea had left rich marine clay deposits. In 1821, Asa Meech founded the town of Chelsea in an area of fertile fields nestled in the Gatineau Hills only a few kilometers northwest of Wrightville, slightly inland from the west bank of the Gatineau River. Farming was more difficult in the hills to the west of Chelsea, where as many as 16 British families attempted to farm the rocky landscape along the top of a ridge that ran from Kingsmere to Meech Lake. In the 1830s and 40s, the community even had its own schoolhouse, but the soil on the ridge was not conducive

37 John H. Taylor, Ottawa: An Illustrated History (Toronto: Lorimer, 1986), 11. 
to farming, and, although some hard working families sustained themselves for a few years, the rock-strewn fields did not offer strong yields. Many of the families gradually abandoned farming on the ridge, and the forest repossessed the idle fields and the buildings fell into disrepair. ${ }^{38}$

The farms along the ridge left behind a grid of rudimentary roads that shaped future recreational uses of the land. An early ski map shows the clearings and roads of the few farmers who remained in the hills until 1931 (Figure 3). The existing and abandoned infrastructure of these farmers allowed skiers to move through this section of the Gatineau Hills, and the roads were the foundation of the trail network that is the focal point of this study. Ridge Road was the central artery of the area, as families settled along the east-west road; Meech Lake Road running from Chelsea to Meech Lake, formed the north border of the area; McCloskey’s Road, connecting Meech Road to the western end of Ridge Road, was the west border; Mountain Road, following the southern edge of the hills, hemmed in the area from the south; and Kingsmere Road, connecting Old Chelsea to the Mountain Road, formed the east edge. ${ }^{39}$ Ridge Road remained the most used avenue through this section of the Gatineau Hills, and Dunlop's Road leading from the Meech Lake Road up towards Fortune Lake became increasingly important as recreational use of the area developed.

In the hills to the southeast of Ridge Road, industrious settlers from Wrightville began mining the rocky slopes on the northern edge of town, leaving another set of work roads in the forests. Philemon Wright and his partner John MacTaggart formed the Hull

\footnotetext{
${ }^{38}$ Charles Mortureux, "The Ridge Road," Ottawa Ski Club Guide 1943 (Ottawa: Ottawa Ski Club Publication, 1943), 8. http://gvhs.ca/digital/gatineau-park/osc/1943-OSC-Guide.pdf (accessed 11 February 2014).

${ }^{39}$ Most recreational maps of the Gatineau Hills use similar boundaries to those outlined here. See Figures $3,4,5$, and 6 .
} 
Mining Company in 1826, and undertook mining to supplement revenue from the timber trade. The mining enterprise remained small-scale until Forsyth and Company of Pennsylvania bought the rights from Wright and MacTaggart in 1854, and began iron ore extraction. The ore was brought from the mine at the extreme southeastern point of the Gatineau Hills to the aptly named town of Ironside, where it was placed on barges and floated three kilometers down the Gatineau to the Ottawa River, and then up the Rideau Canal to Kingston. Production at the Forsyth Mine drastically decreased following a fire that devastated the town of Ironside in $1870 .{ }^{40}$ Mica, though, was the most commonly mined mineral in the Gatineau Hills. Operating from 1904 to the mid 1910s, the Pink Lake Mica Mine, located a few kilometers to the west of the Forsyth Mine, was the largest in the eastern Gatineau Hills. Pink Lake is surrounded on all sides by high bluffs and is the largest lake in this section of the hills. Mica was gouged from surface pits on top of the bluffs on the east and south banks of the lake and taken to Ironside along the Mica Mine Road, where it could then be transported by the newly constructed railway on the west bank of the Gatineau River. ${ }^{41}$

To this day, the open pits and shafts of the long-abandoned Pink Lake and Forsyth mines are a visual reminder of the area's industrial past. The network of access roads built to transport ore from the mines to Ironside long outlived the industries they were designed to support. The network of utility roads that wind, twist, and climb around the abandoned pits permanently changed the landscape and became re-appropriated as

\footnotetext{
40 Shawn Graham, "The Mines of Gatineau Park," The Gatineau Park Chronicle 2007, Gatineau Valley Historical Society, 2007. http://gvhs.ca/digital/gatineau-park/chronicles/mines.html (accessed 11 February 2014).

41 The mica mine at Pink Lake was briefly reopened from 1945-46, when the Pink's Lake Mining Company took over, but the enterprise was short lived and left little physical evidence visible to the naked eye. Graham, "The Mines of Gatineau Park."
} 
recreational trails that brought people into the Gatineau Hills for leisure. These roads became access routes for early skiers and demonstrate the relationship between industry and recreational mobility through the Gatineau Hills.

The city of Bytown, later Ottawa, was located on the opposite side of the Ottawa River. The elevation of the Eardley Escarpment provides a view of the city from the Gatineau Hills, which can be seen from the city, too. As Ottawa assumed the role of national capital, the civil service replaced lumber as the primary industry, and politicians and civil servants replaced a rowdy working class population in a town John Taylor described as having "a multitude of imperfectly digested elements." ${ }^{42}$ The demographic shift in Ottawa affected the forests and lakes of the Gatineau Hills, which underwent significant transformation as city residents sought a rural retreat. In 1903 the Canadian Pacific Railway established service up the Gatineau River to Chelsea, Tenaga, Kirk's Ferry, and Wakefield. ${ }^{43}$ The train linked the growing middle class population to the hills and helped transform the 'Gatineau' from a place of work for local residents to a wilderness landscape of primarily recreational value for visitors from Ottawa. Those who could afford it purchased plots of land in the hills and on the lakes that were accessible by Kingsmere Road and Meech Lake Road. A wealthy and well connected community of cottagers purchased property around Meech and Kingsmere Lakes. The future Prime

\footnotetext{
42 John Taylor, "Ottawa: The City as Conglomerate," Urban History Review, Vol. 4, issue 1 (Jun 1, 1975), 36. http://search.proquest.com/docview/1300108863/6023FB6D19B84839PQ/9?accountid=9894 (accessed 23 February 2014).

43 Bruce Ballantyne, "Stations of the Gatineau Valley Railway,” Up the Gatineau! Vol. 24 (1998), http://www.gvhs.ca/publications/utga-stations.html (accessed 11 February 2014).
} 
Minister Mackenzie King purchased land near Kingsmere Road in 1901, after growing fond of the area on a bicycle trip from the train the previous Thanksgiving. ${ }^{44}$

In 1911, the National Parks Branch of Canada was founded, its office located on Sparks Street in Ottawa. The agency's first promotional booklet, issued in 1914, promoted outdoor recreation in Canada's mountain parks as the "means of recreation which serve best to make better men and women, physically, morally and mentally." 45 Although the Gatineau Hills were not mountains, regular passenger service from Ottawa allowed residents to access the same type of outdoor recreation promoted by the Parks Branch.

In the early twentieth century, sports clubs were becoming popular in Canadian cities as a way of promoting health and of creating group identity. In her work on sports clubs and winter carnivals in nineteenth century Montreal, Gillian Poulter argued that urban residents who enjoyed financial stability and leisure time shared holistic activities and created a sense of community rooted in sport and similar class values through these clubs. ${ }^{46}$ The growing civil service in Ottawa fostered a large community of middle class government employees with free time on Sundays and in the evenings. Long winters limited recreational options for much of the year and forced adult residents to choose a

\footnotetext{
44 Dennis Duffy, "Love Among the Ruins: The King of Kingsmere," American Review of Canadian Studies, Vol. 37, issue 3 (October 2007), 358. http://journals2.scholarsportal.info.proxy.library.carleton.ca/pdf/02722011/v37i0003/355 latrtkok.xml (accessed 23 February 2014); The date of 1901 is disputed, as Gagnon and Filion state 1903 as the year King "purchased a country home on Kingsmere Lake," and Fletcher's book indicates 1902 at the year in which King acquired his first lot. Filion and Gagnon, The Creation and Early Development of Gatineau Park, 4; Fletcher, Historical Walks, 48.

45 A Sprig of Mountain Heather; Being a Story of the Heather and Some Facts about the Mountain Playgrounds of the Dominion (Ottawa: Department of the Interior, 1914), 16. Cited in Alan MacEachern, "M.B. Williams and the Early Years of Parks Canada," in A Century of Park Canada, 1911-2011, ed. Claire Elizabeth Campbell (Calgary: University of Calgary Press, 2011), 32.

${ }^{46}$ Gillian Poulter, Becoming Native in a Foreign Land: Sport, Visual Culture, \& Identity in Montreal 184085 (Vancouver: UBC Press, 2009), 5.
} 
suitable winter activity. For those interested in practicing individual sports, like snowshoeing, ice-skating, or skiing, joining a club offered members a community of people with shared recreational interests, while promoting physical health, moral virtue, and the middle class values of a predominantly civil-servant population. ${ }^{47}$ The proximity and accessibility of the Gatineau Hills made them an ideal location for a growing outdoor recreational culture.

Nordic skiing was brought to Canada by Scandinavian immigrants who grew up practicing the sport in Europe. Herbert Marshall's History of the Ottawa Ski Club refers to a Norwegian who skied from Montreal to Quebec City in 1879, on "a pair of so-called Norwegian snowshoes: nine feet long, six inches wide," as one of the earliest accounts of skiing in Canada. ${ }^{48}$ Nordic skiing involved tramping through the snow with a large wooden plank strapped to each foot, and a single pole was used to aide balance on descents and as an oar on flat stretches and climbs. ${ }^{49}$ Unlike Canadian snowshoes, the Norwegian version allowed a person to slide downhill and jump through the air. Nordic, or 'cross-country,' skiing along trails was the more popular choice for men and women of Ottawa looking to enjoy the winter air. ${ }^{50}$ In the early years, jumping was a very popular spectator sport. It involved the erection of impressive ski towers from which jumpers gained speed before hurtling into the air, eventually landing on a prepared hill. The goal was to soar as far as possible while maintaining proper technique during flight.

\footnotetext{
${ }^{47}$ Poulter, Becoming Native in a Foreign Land: Sport, Visual Culture, \& Identity in Montreal 1840-85, 5. Poulter argued that sports clubs in Montreal helped British immigrants to Canada construct a distinct national identity, while valorizing stamina, pluck, moral virtue, and the promotion of middle-class values. I do not explore nationalism or gender in the Ottawa Ski Club, but the idea of the social role of the club presented by Poulter is valuable to this study.

48 Marshall, The History of the Ottawa Ski Club, 3.

49 Coleman, Ski Style, 18.

${ }^{50}$ From the very beginning of the Ottawa Ski Club Newsletters women were included and encouraged to partake in trail skiing.
} 
In 1910, Norwegian Sigurd Lockeberg founded the Ottawa Ski Club (OSC) with two friends Frank Bedard and Joe Morin. They created the club to promote skiing, but also to raise funds for the construction of spectacular ski jumps; the membership fees provided funds for a club that "had or planned to have, real assets in the shape of towers and landing hills.. ${ }^{, 1}$ Lockeberg who served as president, was a ski jumper who participated in the design and construction of the jumps. The club's early members worked tirelessly to build increasingly large jumps, and interested crowds gathered in Rockcliffe, east of the city, to watch skiers jump up to 145 feet. ${ }^{52}$ Because the jumps regularly fell victim to high winds and were rebuilt several times, the club experienced financial strain early on. The OSC began to operate in the Gatineau Hills in 1907, using the Fairy Lake Hill in Hull, and then under the presidency of C.E. Mortureux running races from the Murphy Boarding House in Kingsmere to Rockcliffe Park. ${ }^{53}$

During the First World War the OSC ceased normal operations but Morin, Mortureux and fellow members George Audette, and Alex Haultain began exploring the Gatineau Hills on their skis and building the first trails. ${ }^{54}$ The area bounded by Meech Lake, Mountain, McCloskey's, and Kingsmere Roads (Figure 2) provided the topography for exciting skiing and was easily accessed from the train. The most suitable paths to navigate the rolling landscape were the old farm roads intersecting Ridge Road, and the

\footnotetext{
${ }^{51}$ Marshall, The History of the Ottawa Ski Club, 6.

52 Marshall, The History of the Ottawa Ski Club, 9.

53 Fletcher, Historical Walks, 56.

54 "To the Members of the Ottawa Ski Club," Ottawa Ski Club Newsletter 'Gold Watch' (February 1922). http://gvhs.ca/digital/gatineau-park/osc/1922-02-10-Mort-Gold-Watch.pdf (accessed 11 February 2014). Mortureux' efforts were recognized and he was awarded a gold watch; Marshall, The History of the Ottawa Ski Club, 22. I was unable to find any written record of the trails built during the First World War. Judging by the newsletters and Marshall's The History of the Ottawa Ski Club, Cooper's and McAllister's were the first trails cleared specifically for skiing in the area.
} 
mining roads near Pink Lake and the Forsythe Mine, which were seldom used in winter; they also skied directly across farmer's fields and jumped over fences on their trips.

By 1919, members of the OSC were using a few ski-touring trails built during the war in conjunction with the farming roads to reach a valley nestled in the center of the developing recreational area in the Gatineau Hills, at the top of Dunlop Road, these trips from the "ski trains" were very popular in the first winter of club operation following a hiatus during the First World War. ${ }^{55}$ Skiers could get off the train at Kirk's Ferry or Tenaga and choose between McAllister's or Cooper's Trail to access the hills. The two trails leading from the train to the hills had similar start and end points, but offered different experiences along the way. McAllister's was a more direct route, but featured an unrelenting initial climb, whereas Cooper's trail alleviated the grade by stretching out the climb over a greater distance. Both trails led skiers to Meech Lake Road where it intersected Dunlop Road, neither of which were cleared of snow in winter at this point. ${ }^{56}$ Here skiers ascended once again, this time up Dunlop Road, into a valley that featured the best skiing terrain discovered thus far by members of the OSC. Records of early ski trips through the park show skiers going from the valley, up to Ridge Road, which they followed until Kingsmere, where they could take the Mica Mine Trail to Wrightville via Pink Lake, and finally take the streetcar back to Ottawa. The Kirk's Ferry-KingsmerePink Lake-Wrightville loop was the most popular ski at this time and traffic on the route soon increased. ${ }^{57}$ Audette and Haultain also led ski trips almost 20 miles long up from the

\footnotetext{
55 Marshall, The History of the Ottawa Ski Club, 10.

56 Snow removal only began following the creation of Gatineau Park and was done by the Federal District Commission, who cleared Meech Lake Road as far as Dunlop's and Kingsmere Road to the Mountain Lodge.

57 Early club newsletters advertised this as a popular route. Ottawa Ski Club Opening Hikes," Ottawa Ski Club Newsletter No. 1 (January 1921). http://gvhs.ca/digital/gatineau-park/osc/1921-01-01.pdf (accessed
} 
fields along the edge of the Gatineau River into the hills; most of these miles were along the farm and mining roads. ${ }^{58}$

To better accommodate their growing membership, the OSC executive purchased a 168 square foot woodcutter's shack and 315 acres of land in the picturesque valley at the top of Dunlop Road in 1920. They named the lodge Camp Fortune, after the previous owner, Garrett Fortune. ${ }^{59}$ Once Camp Fortune was in operation, skiers had a place to seek refuge from the cold in the heart of their skiing paradise, and enjoy a hot meal with fellow club members before continuing their day. The club also purchased a second lodge, near Pink Lake to the southeast of the Kingsmere-Camp Fortune area, where the work roads of the mines served as trails, and the hills were gentler. ${ }^{60}$ Lodges were an important part of ski infrastructure and time in the lodges were part of the Sunday ski experience in the Gatineau Hills.

By 1921, Sunday ski trips had become popular enough for the OSC to produce a list of seven refuges welcoming skiers in from the cold. The club owned and operated their lodges at Pink Lake and Camp Fortune, while the remaining five were privately owned. ${ }^{61}$ Issued on January 1, 1921, the club's inaugural newsletter invited members to

11 February 2014); “To the Members of the Ottawa Ski Club," Ottawa Ski Club Newsletter No. 2 (January 1921). http://gvhs.ca/digital/gatineau-park/osc/1921-01-13.pdf (accessed 11 February 2014); "Circular \#3 Activities," Ottawa Ski Club Newsletter No. 3 (January 18 ${ }^{\text {th }} 1921$ ). http://gvhs.ca/digital/gatineaupark/osc/1921-01-18.pdf (accessed 11 February 2014).

58 Marshall, The History of the Ottawa Ski Club, 22. The trips were nearly twenty miles long, but they mostly followed the farm and mining roads through the hills, as the trail network was not very developed in 1921.

${ }^{59}$ The origin of the name "Fortune" is a contested point within the Ottawa Ski Club. In 1942, Charles Mortureux's "Saga of the Ottawa Ski Club" attributes it to the mispronunciation of "Lac Fortin," the lake's original name. While Herbert Marshall's 1972 The History of the Ottawa Ski Club, Denis Messier's 2007 Gatineau Park Chronicle, and J. David Andrews Gatineau Park: An Intimate Portrait relate it to Garrett Fortune, the former owner of the woodcutter's shack purchased by the club in 1920. Mortureux's apparent error is interesting considering the amount of time he spent in the area.

60 “Circular \#3 - Activities," Ottawa Ski Club Newsletter No. 3 (January 18 $8^{\text {th }} 1921$ ). http://gvhs.ca/digital/gatineau-park/osc/1921-01-18.pdf (accessed 11 February 2014).

${ }^{61}$ Marchall, The History of the Ottawa Ski Club, 14. 
make the trip out to Camp Fortune and instructed them to "take the Gatineau train, at Central Station, 9 a.m. Train will be met at Kirk's Ferry by OSC guides. Return trip via Kingsmere, with supper at Murphy's." ${ }^{2}$ The modest shack at Fortune offered skiers who had made the long trek a chance to warm up and a space to socialize and share the experience of a day in the winter landscape. Distributed to the membership of about 80 , the subsequent newsletters encouraged skiers to "Bring a friend along" for the guided cross-country ski trips up McAllister's and Cooper's Trail to Camp Fortune. ${ }^{63}$ The publication referenced trail and place names, often given by the volunteer club members who cleared the trails and led the trips. Already, the Gatineau Hills were being inscribed with meaning by skiing's vernacular, through the naming of trails and lodges, as the recreational role of the area grew.

Many of the early trails were built thanks to the guidance and labour of Mortureux, a resident of Ottawa who was president of the OSC from 1919 until $1947 .{ }^{64}$ In 1922, the OSC Newsletter recognized that "If it were not for his constant thought, care and work, even manual labour, the club would be something far different, if at all in existence, from what it is today." 65 Mortureux was francophone, and the language of skiing in the Gatineau Hills, and of the British families still farming there, as well as the neighbouring rural communities of Chelsea and Wakefield, was predominantly English. In the records of the club, and in the interviews conducted with avid skiers of following generations, language was not understood to have been a barrier between skiers sharing

62 "Ottawa Ski Club Opening Hikes," Ottawa Ski Club Newsletter No. 1 (January 1921). http://gvhs.ca/digital/gatineau-park/osc/1921-01-01.pdf (accessed 11 February 2014). Murphy's was a boarding house on Kingsmere Road that was popular among members.

63 "To the Members of the Ottawa Ski Club," Ottawa Ski Club Newsletter No. 2 (January 1921). http://gvhs.ca/digital/gatineau-park/osc/1921-01-13.pdf (accessed 11 February 2014).

64 Marshall, The History of the Ottawa Ski Club, 97.

65 "To the Members of the Ottawa Ski Club," Ottawa Ski Club Newsletter 'Gold Watch' (February 1922). http://gvhs.ca/digital/gatineau-park/osc/1922-02-10-Mort-Gold-Watch.pdf (accessed 11 February 2014). 
the recreational space. Anglophones and francophones appear to have shared the trails, hills, and lodges on equal terms, as skiers and members of the OSC. ${ }^{66}$

In the early years of skiing in the region, the OSC was not the only choice for skiers looking to enjoy the sport among a group of their peers. Started after the OSC, the Cliffside Club offered its membership, capped at 350 in 1919, a different kind of ski experience. Cliffside members had two lodges of their own: the main lodge at Fairy Lake, at the southern entrance to the Gatineau Hills, which offered food and refreshments to skiers at a centralized location, and Keogan's Lodge off the Ridge Road, just southwest of Camp Fortune. Members were encouraged to arrive by Hull Electric train and take advantage of the slopes located in the immediate vicinity. ${ }^{67}$ There was also a ski jump on site that was larger than the OSC's Rockliffe jump.

Keogan's Lodge served a similar role as the OSC's Fortune Lodge. It was a refuge for skiers exploring the roads and trails of the Gatineau Hills in the KingsmereCamp Fortune area. ${ }^{68}$ Keogan's Lodge remains one of the central refuges in Gatineau Park today, and has been the subject of recent local history projects. ${ }^{69}$ Cliffside skiers shared the main trail arteries with the OSC, whose members voluntarily cleared them in the fall. Ridge Road and the Mica Mine Trail through Kingsmere were the only access routes to Keogan from Fairy Lake, and the route linking Wrightville to Pink Lake

\footnotetext{
${ }^{66}$ In interviews, when asked "Was there a rift between anglophone and francophone skiers based on language?" Mr. MacConaill, the Allers, Mr. Woods, and the Midgleys all denied the presence of linguistic tension. They were all anglophone. Woods identified himself as francophone, but spoke English flawlessly.

${ }^{67}$ John Graham, "The Cliffside Ski Club of Ottawa," Canadian Ski Annual 1923-24, 34. http://www.skimuseum.ca/documents/annuals/1923-24_pt16 pg34-39.pdf (accessed 11 February 2014). 68 "Cliffside Ski Club," Canadian Ski Annual 1925-26, http://www.skimuseum.ca/documents/annuals/1925-26_pt13_pg29-31.pdf (accessed 11 February 2014), 29-31.

${ }^{69}$ Guide Gatineau, "Keogan Lodge and the Rise and Fall of the Cliffside Ski Club," (February 2011). YouTube. http://www.youtube.com/watch?v=yN9YpKm2RR4 (accessed 11 February 2014).
} 
remained popular long after Cliffside was defunct. Both clubs' executives operated separately and their members wore the visual identification of their respective club in the form of a patch or badge, making their association visible on the trail.

The two clubs initially jockeyed for position as the more prominent organization for skiing in the region. Cliffside promoted its facilities at Fairy Lake for their proximity to Ottawa, easy accessibility by car, on site concessions, conveniently located slopes, and a ski jump that was "probably the best on the continent." ${ }^{\text {"70 }}$ The OSC marketed guided ski tours to its members from one of the train stops on the Gatineau River to either Camp Fortune or Pink Lake Lodge. Membership fees were the primary source of revenue. The two clubs were not profitable enterprises in the 1920s; the OSC had expressed its financial difficulties to members as early as 1922 . Membership and the fees it entailed were essential to club prosperity, and members were constantly reminded of this. ${ }^{71}$ Ski equipment at the time was relatively primitive, and skiing itself was still a new experience for many people, so the proximity and less demanding terrain of Cliffside's Fairy Lake facility was enticing to first time skiers.

Skiing in the Camp Fortune valley, and visits to the lodges at Kingsmere, Keogan and Pink Lake were primarily Sunday outings. These trips required a large time investment and were physically demanding, as skiers were forced to cover at least ten miles of trail to make a return trip. The primarily government-employed recreational community worked on Saturday mornings, so Saturday skiing was only an afternoon affair. The scarcity of free time made smaller ski areas that benefited from proximity to

\footnotetext{
${ }^{70}$ John Graham, "The Cliffside Ski Club of Ottawa," Canadian Ski Annual 1923-24, http://www.skimuseum.ca/documents/annuals/1923-24_pt16_pg34-39.pdf (accessed 11 February 2014), 34.

${ }^{71}$ From the 1922 Newsletter to the last yearbook of 1962, finances were a constant issue in the club's publications.
} 
Ottawa a convenient and logical way of skiing. The OSC secured the rights to ski on a small hill near the former town of Ironside in November $1920 .{ }^{72}$ Known as the Dome Shaped Hill, the hill and a small lodge were easily accessible by bus, train, and streetcar. This facility directly competed with the Cliffside Club's Fairy Lake ski area, and was very popular with beginners and young skiers looking to try skiing in a more forgiving atmosphere than the taxing trips to Camp Fortune.

For Ottawa residents, there were also weekday evening ski outings in Rockliffe Park. OSC newsletters advertised ski outings by moonlight during the week, usually on Thursday nights. ${ }^{73}$ After all, some skiing was better than no skiing, and evening outings were popular social events in other sports clubs. ${ }^{74}$ Sunday outings, however, were a much more serious affair. Skiers would leave their homes early in the morning, make their way to a trailhead either by train, bus or car, ski out to a lodge where they ate lunch, and ski back to the vehicle that took them to the trails that morning. These Sunday outings were the main stage for the ski experience of members of ski clubs during the interwar period and they shaped local ski culture and the landscape of recreation in the Gatineau Hills.

Keogan, Camp Fortune, and Pink Lake Lodges were located at a considerable distance from either railroad stops or parking lots. Skiers who made the trips were required to be self-sufficient and possess a certain level of physical fitness. Moving into the 1920s, roads were improved and plowed, and cars and buses could bring skiers closer to the lodges. These changes in accessibility brought more people onto the trails then ever before. Total membership in the OSC grew exponentially in the 1920 s. With only 80

\footnotetext{
72 Marshall, The History of the Ottawa Ski Club, 15.

73 “Ottawa Ski Club Newsletter No.5," (February 1922). http://gvhs.ca/digital/gatineau-park/osc/1922-0202.pdf (accessed February 112014 ).

74 Poulter, Becoming Native, 55.
} 
members in 1920, by 1930 the club had well over 1000 members and was printing 2400 copies of the Ottawa Ski Club Newsletter.$^{75}$ The Cliffside Club had over 400 members of its own in 1926, but they had trouble competing with the rapidly expanding and innovative OSC.

The 1920s also saw the most significant development of ski trails in the Kingsmere-Camp Fortune area. Construction was undertaken to deal with the changes in mobility that allowed skiers to begin their ski trips much closer to Camp Fortune. Starting next to the farm roads along the ridge that previously served as the principle trail network, the club cleared many of the best known trails in its recreational infrastructure during this period. George Audette built George's Trail from Camp Fortune to Kingsmere Lake in 1922; the Merry-Go-Round loop, which started and finished near Fortune Lodge, was ready for the season of 1925; the Canyon Trail from Old Chelsea to Camp Fortune in 1926; the Western Trail was built in 1930; Little Switzerland and the Highland Trail were also cleared in this period. The transition from skiing on farm roads to navigating purpose-built ski trails was possible thanks to the volunteer labour provided by Joe Morin and a group of enthusiastic young men known as the Night Riders of the Canyon. As president, Mortureux participated in the activities of the Night Riders, but was not an official member. The trails they built around Camp Fortune in this period navigated steep hills and scenic lookouts, catering to skiers' desires to appreciate a perceived wilderness aesthetic and the physical experience of skiing; many hills were dangerous enough to earn names like "Suicide Hill," "Ogopogo," or "Kicking Horse."76

\footnotetext{
75 “Ottawa Ski Club News,” No. 2 (January 1930), 1. http://gvhs.ca/digital/gatineau-park/osc/1930-0108.pdf (accessed February 11 2014).

${ }^{76}$ Marshall, The History of the Ottawa Ski Club, 26.
} 
Poulter's work on $19^{\text {th }}$ century snowshoeing clubs in Montreal suggests snowshoers' inclination to choose trails covered in fresh snow allowed them to relive the experience of conquest of the landscape. Moving through the area of Mont Royal, already covered with settlement trails, farming, and logging road, the snowshoers explored new routes across these lines of mobility according to the needs of their recreational sport, and in practice transformed agricultural space into recreational territory. ${ }^{77}$ Snow erased the earlier landscape and effectively transformed the forests into a blank canvas upon which new recreational meaning was inscribed. The OSC's massive expansion of their trail network during the interwar period led to mapping projects and the expansion of lodges. The work of the Night Riders transformed the rural farm landscape of the KingsmereCamp Fortune area into a recreational territory for a group of middle and upper-class skiers from Ottawa.

At Camp Fortune, club membership rapidly outgrew the original 168 square-foot woodcutter's shack and, by 1926, the Fortune Lodge had relocated to the top of a knoll in the northwest corner of the valley and expanded to 4,424 square feet to accommodate the growing ski community. ${ }^{78}$ The OSC pursued lodge expansion and trail development at a heated pace around Camp Fortune to satisfy a membership that was growing in size and developing more sophisticated skiing needs. Winter access to Camp Fortune was also improving. Bus service to Chelsea brought skiers closer to the trails, allowing them to go farther afield by ski, or to explore the many trail loops around Camp Fortune. The club increasingly consolidated its resources at Camp Fortune and the trails branching out from

\footnotetext{
77 Poulter, Becoming Native, 48.

${ }^{78}$ Marshall, The History of the Ottawa Ski Club, 17.
} 
the valley and the lines of recreational mobility that textured the landscape became more complex.

In January 1930, the OSC newsletter included the first trail map of the Gatineau Hills produced for club members (Figure 1). The map outlines "Flat Trail," Pink Lake Lodge, and the Mica Mine Trail, as well as the roads crossed by the trails. Improved winter maintenance of Mountain Road and the depiction of its proximity to Pink Lake Lodge on the early 1930 map were meant to encourage beginners to explore the Gatineau Hills by ski. The map and accompanying article promoted Flat Trail as an introductory route with very few of the dangerous hills dreaded by beginners. "We recommend it to old ladies and Gatineau juniors," the editor of the newsletter noted sarcastically. ${ }^{79}$ The colloquial names of some of the dangerous hills near Camp Fortune - Humdinger Ravine, Mile a Minute, Horse Race -- may have dissuaded novice skiers from exploring the area, which may have been partially the intention. The Flat Trail's location, in the southern section near Pink Lake Lodge and the mining roads in the area, was miles from the more precipitous hills of Camp Fortune, and was the first attempt by the OSC to identify and order spaces according to a skiers' skill level. ${ }^{80}$ The following year, the club issued the first comprehensive trail and road map of the Kingsmere-Camp Fortune area (Figure 2); the boundary of the map outlined the club's recreational space in the Gatineau Hills.

\footnotetext{
79 “Ottawa Ski Club News,” No. 2 (January 1930), 5. http://gvhs.ca/digital/gatineau-park/osc/1930-0108.pdf (accessed February 11 2014).

80 As the OSC's ski infrastructure developed, and membership grew, ski areas became increasingly ordered according to difficulty.
} 


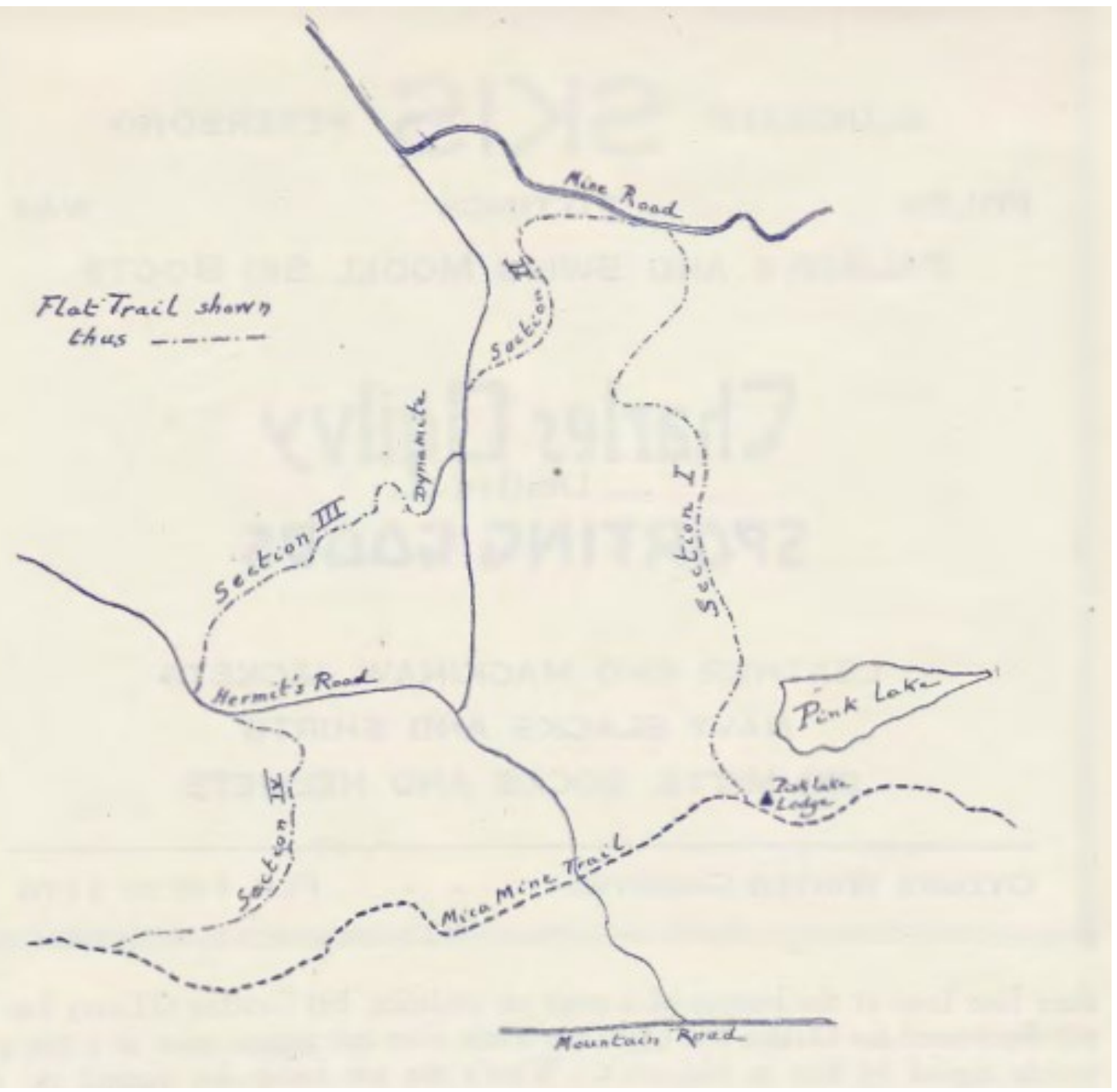

Figure 2: Ottawa Ski Club Flat Trail Map, January 8, 1930.

One of the commonly travelled ski routes during this period was from Camp Fortune to Pink Lake, via Ridge Road or George's Trail, both of which crossed Kingsmere Road before crossing Mackenzie King's estate and meeting the Mica Mine Trail to Pink Lake. Skiers taking either route easily found Kingsmere Road after navigating a few kilometers of trail, where they then skied across the frozen surface of Kingsmere Lake. If a skier was unfamiliar with the route, and was unaware of the lake crossing, a fresh snowfall could easily conceal the recognizable parallel lines of a ski 
track, and the traverse would not be obvious. ${ }^{81}$ The 1931 OSC map depicted roads, lakes, lodges, and the already well developed trail network. (Although not depicted on the 1931 map, King's estate at Kingsmere was immediately to the south of the lake, bisected by the Mica Mine Trail that led to Pink Lake.) Members of the Ottawa Ski Club used the map to navigate the space and familiarize themselves with the landscape and colloquial names of landmarks.

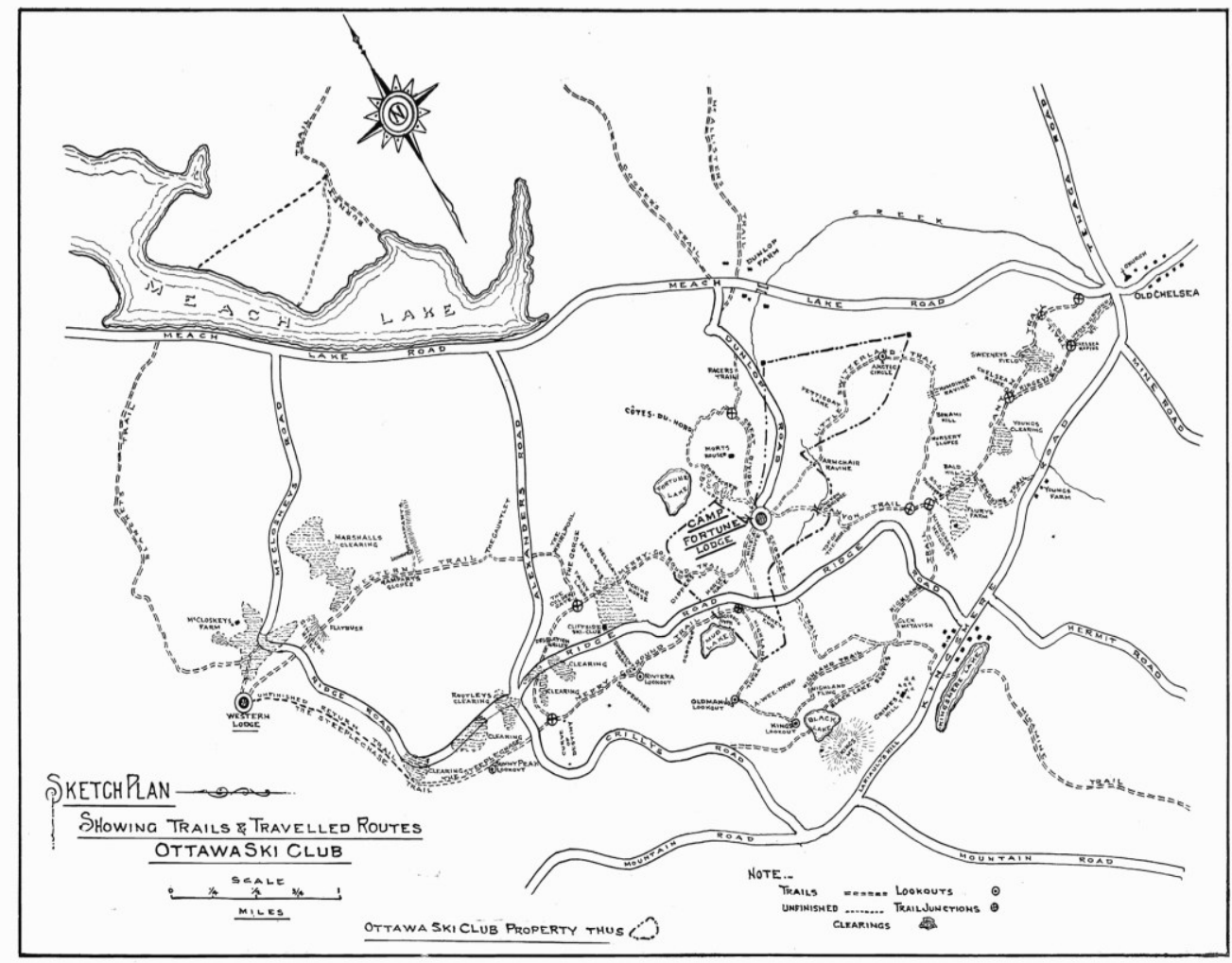

Figure 3: Ottawa Ski Club Trail Map, 1931.

OSC members received a copy of this map with their membership and would bring the maps with them as a guide when navigating the landscape on skis ${ }^{82}$ Along with trails,

81 Michael MacConaill, interview by the author, November 13, 2013, Gatineau, QC, digital recording.
82 Michael MacConaill, interview by the author, November 13, 2013, Gatineau, QC, digital recording. 
the map identified scenic lookout points, lodges, hills, intersections, roads, lakes, and clearings. Names helped skiers understand the terrain each trail offered and enriched conversations between club members who could demonstrate their knowledge of the area by using the appropriate names for each landmark. ${ }^{83}$ As the recreational needs of a burgeoning ski culture reinterpreted abandoned industrial and farming roads, and created its own network of trails through the winter landscape, the geography of the KingsmereCamp Fortune area became inscribed with new meaning. For skiers, this was a sports geography, where the changing spatial requirements of skiing altered the landscape. ${ }^{84}$

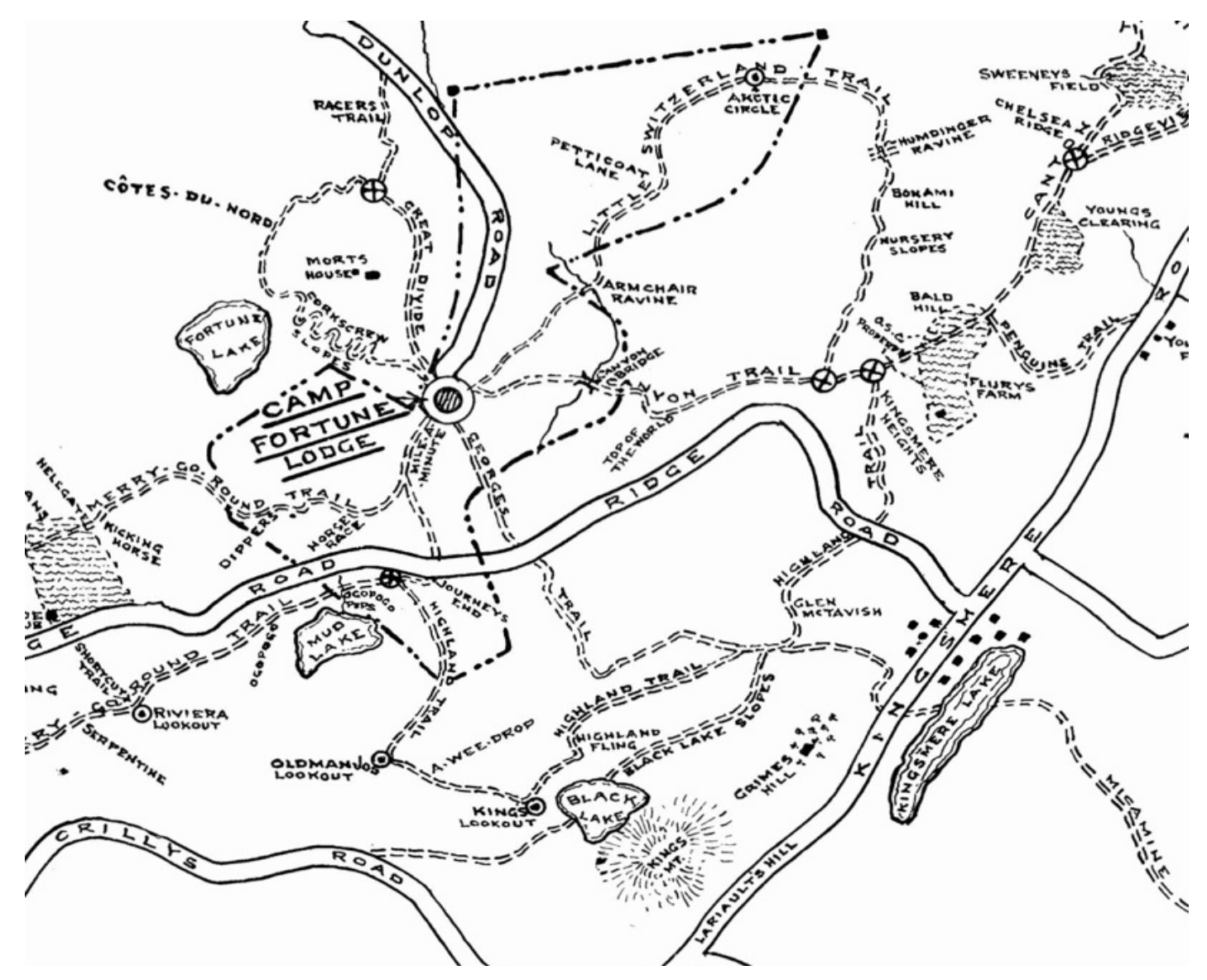

Figure 4: Zoom of Kingsmere-Camp Fortune area, 1931 OSC map.

83 All interviewees referred to the trails only by their original names, unless trying to clarify the former location of a defunct trail according to existing trails, which are now numbered, and have no names.

84 John Bale, Sports Geography, 5. 
As traffic increased during the 1930s, the OSC trails required constant maintenance in the winter months. The responsibility of the Night Riders transitioned from trail development to predominantly trail maintenance in this period. As early as 1930, members lamented the condition of trails, accusing the Night Riders' ineptitude for "abominable" trail conditions. ${ }^{85}$ Composed mostly of high school students under the guidance of an experienced "Captain," the Night Riders were responsible for the yearround maintenance of the trail network. ${ }^{86}$ In winter, after a snowfall, they set tracks on flat sections of trail by skiing through the new snow in single file. The tracks helped guide skiers along trails and made skiing faster and less exhausting for the droves of Sunday skiers. On hills, where skiers executed turns or placed the front tips of their skis together in the form of a snowplow to control their speed, the Night Riders packed down the entire width of the trail by "cross-checking." 87 The smoothened surface made it easier for skiers to control their speed, reduced the risk of falls, and minimized the formation of dangerous ruts. Track setting and 'cross-checking' were the main winter responsibilities of the Night Riders; they were done on Friday evenings and Saturday mornings. In fall, the young men spent every weekend from Labour Day until the first snowfall clearing trails of deadfall, cutting brush by hand, building bridges, and clearing new trails. The

\footnotetext{
85 “Ottawa Ski Club News No.2,” (January 8, 1930), 4. http://gvhs.ca/digital/gatineau-park/osc/1930-0108.pdf (accessed 23 February 2014).

${ }^{86}$ James S. Patrick, "Saga of the Night Riders," Ottawa Ski Club Yearbook, 1955-56 (Ottawa: Ottawa Ski Club Publication, 1956), 53-54. http://gvhs.ca/digital/gatineau-park/osc/1955-1956-year-book.pdf (accessed 11 February 2014).

87 'Cross-checking' is the process of compressing newly fallen snow by side-stepping up a hills with skis, creating a level, hard-packed surface better suited for turning or slowing down.
} 
OSC gave the Night Riders free annual membership and modest overnight accommodation at Camp Fortune on weekends in fall and winter. ${ }^{88}$

In 1931, the road to Kingsmere was kept clear of snow over winter, and for the first time skiers could take the bus directly to Kingsmere bringing them even closer to Camp Fortune by motorized transit. Taking the bus, either to Old Chelsea or Kingsmere, greatly reduced the distance OSC members had to cover by ski before reaching their favourite trails and hills. The practice of skiing was also changing. As the Night Riders began developing trails and hills around Camp Fortune, skiers spent an increasing amount of time perfecting turning techniques and skiing more difficult terrain. The trails emanating from Fortune Lodge were highlighted by the hills they offered. The Cote du Nord, Great Divide, and Racer's Trail on the hill to the west of Dunlop's Road (Figure 4) were close to the lodge at Fortune and offered consistent downhills once a skier had climbed to the top. These were among the first trails that kept skiers in one area as they climbed and descended three trails using different sides of the same hill.

From Camp Fortune, skiers also took the very popular Merry-Go-Round Loop that climbed out of the valley up Mile-A-Minute, and then navigated a series of hills connected by climbs and lake traverses. Two hills near the start of the Merry-Go-Round, the Big and Little Dippers, had steep descents that quickly transitioned to steep climbs. The momentum from descending the Big Dipper put a great deal of force on skiers, who commonly fell on their backsides from the compression, "dipping" their butts in the snow. The Little Dipper had a longer transition between descent and climb, so the compression was less intense. Staying upright through the Dippers would have been an

8888 James S. Patrick, "Saga of the Night Riders," Ottawa Ski Club Yearbook, 1955-56 (Ottawa: Ottawa Ski Club Publication, 1956), 53-54. http://gvhs.ca/digital/gatineau-park/osc/1955-1956-year-book.pdf (accessed 11 February 2014). 
impressive feat in the 1930s. The Kicking Horse and Ogopogo hills also put skiers' downhill technique and nerves to the test, as great speeds could be achieved on these hills. ${ }^{89}$ Trails in the Camp Fortune area presented skiers with the opportunity to challenge themselves on difficult hills and reach exhilarating speeds. For many, the strong sensation of skiing hills was more attractive than the more relaxed tempo of long distance ski touring.

In 1932, the Joe Morin Slalom Hill was cleared and skiers had a much wider surface on which to practice their downhill technique and enjoy the sensation of making broad turns on snow. ${ }^{90}$ Skiers relied on their own strength to bring them to the top of the Slalom, and some repeatedly climbed and descended the hill in order to maximize time spent descending. The thrill of descents was not restricted to the hills at Camp Fortune, though, as some members of the OSC called out the Night Riders and Morin for making the surrounding trails too easy. "He may know something about road making, judging by the Canyon, but he does not know the first thing about trails." ${ }^{\text {91 }}$ Clearly, this member preferred the precipitous hills and narrow avenues of George's, the Merry-Go-Round, and the Highland Trail. The trails in the early 1930s were sought out for their exhilarating hills, a sensation Camp Fortune gradually came to monopolize in Gatineau Park in the following decades.

\footnotetext{
89 The author has skied the Merry-Go-Round on several occasions during the winter of 2013-2014, and visited them in October 2013, before they were blanketed in snow. Even today, on modern back-country skis, the Dippers are challenging to navigate. David Midgley told a story of a fellow knocking himself unconscious on the Big Dipper, when his head struck a can of peaches in his rucksack. David Midgley, interview by author, November 12, 2013, Gatineau, QC, digital recording.

90 "Ottawa Ski Club News," No.1 (December 1, 1932). http://gvhs.ca/digital/gatineau-park/osc/1932-1201.pdf (accessed 11 February 2014).

91 “Ottawa Ski Club News No.2,” (January 8, 1930), 4. http://gvhs.ca/digital/gatineau-park/osc/1930-0108.pdf (accessed 23 February 2014).
} 
While Camp Fortune could not yet be reached directly by car or bus in the 1930s, regular winter service to Kingsmere brought skiers even closer to Camp Fortune, which they reached via Ridge Road, the Penguin Trail, and the Canyon Trail. The less energy skiers used getting to Camp Fortune, the more they could enjoy the slopes and practice technique, either for personal improvement, or in preparation for competition. Parking lots and accessibility by road were precipitated by a marked rise in automobile ownership in Canada, which had more than doubled between 1921 and 1931, before dropping for three years. ${ }^{92}$

On the weekend of February 25-26, 1933, the Ottawa Ski Club hosted the Canadian Ski Championships for the first time. The Championship attracted athletes from across the country who competed in a slalom race, a jumping competition, and a twelvemile cross-country race. Hill and trail events were held at Camp Fortune, but the jumping took place at Rockliffe Park, as there was as yet no suitable jump at Fortune. Spectators were charged 25 cents to watch the jumping competition, always the most popular spectacle, and crowds watched in awe as the country's best ski jumpers attempted to fly further than one another. ${ }^{93}$ While the OSC had held cross-country and jumping competitions in the past, it held its first ever slalom event at the Championships on the Joe Morin Slalom run. ${ }^{94}$ With favourable weather and new snow, the trails and hills of

\footnotetext{
92 Automobile ownership in Canada grew from 464,805 in 1921 to 1,200,668 passenger vehicles in 1931. Statistics Canada, Historical Statistics, Table T147, http://www.statcan.gc.ca/pub/11-516x/sectiont/T147_194a-eng.csv (accessed 24 February 2014).

93 “The Ottawa Ski Club News," No. 7 (March 9, 1933). http://gvhs.ca/digital/gatineau-park/osc/1933-0309.pdf (accessed 11 February 2014).

94 “The Ottawa Ski Club News,” N0. 6 (February 21, 1933). http://gvhs.ca/digital/gatineau-park/osc/193302-21.pdf (accessed 11 February 2014).
} 
the OSC met the national standard and the race was touted as a success by the club. ${ }^{95}$ The national level race was a chance for Ottawa racers to compete on their home hill, and for visiting skiers to experience skiing at Camp Fortune first hand.

As the OSC transformed the section of the Gatineau Hills around Camp Fortune into a recreational network of trails, slopes, and lodges, steps were taken that lead to the eventual creation of Gatineau Park. The establishment of forest reserves near Ottawa had first been suggested by Frederick Todd in 1903, in the Preliminary Report to the Ottawa Improvement Commission: "The Dominion of Canada is famous the world over for the extent and beauty of her forests, and for this reason it would seem appropriate that there should be reserved in close proximity to the Capital, good examples of the forests which once covered a great portion of the country." 96 One of the proposed reserves was the “Gatineau Valley Reserve.” No action had been taken on Todd's proposal but the idea was in the air; it resurfaced in the Holt Report of 1915, and appears in the diaries of Prime Minister King. In response to a proposed train line through Gatineau by the Canadian Pacific Railroad Company in 1927, he wrote in his diary: "My feeling is this is the time to prevent an impediment to the later development and to begin the National Park idea." 97 In 1928, an amendment to the Federal District Commission Act vested the

\footnotetext{
95 “The Ottawa Ski Club News,” No. 7 (March 9, 1933). http://gvhs.ca/digital/gatineau-park/osc/1933-0309.pdf (accessed 11 February 2014).

96 Frederick G. Todd, "Large Natural Parks or Reserves," Preliminary Report to the Ottawa Improvement Commission (Ottawa: Ottawa Improvement Commission, 1903), 8. https://qshare.queensu.ca/Users01/gordond/planningcanadascapital/todd1903/Page $\% 203 \% 200$ order\%20of\% 20Parks.htm (accessed 4 March 2014).

${ }^{97}$ William Lyon Mackenzie King, “The Diaries of Prime Minister William Lyon Mackenzie King," (April 26, 1926), 116. https://www.collectionscanada.gc.ca/databases/king/001059-119.02e.php?\&page id_nbr=9840\&interval=20\&\&PHPSESSID $=5$ df1 pekolkfts4indi1638mb36 (accessed February 11 2014). Prior to this statement, the idea of Gatineau Park existed only in the form of proposals for forest reserves in the Gatineau Hills, which included maps, for the Ottawa Improvement and Federal District Commissions. Frederick G. Todd, Preliminary Report to the Ottawa Improvement Commission
} 
commission "with the necessary powers to expropriate lands in the Province of Quebec, as elsewhere, without the co-operation by the provincial legislature." ${ }^{98}$ Equipped with such legislative authority, the Federal District Commission (FDC) became the instrument of government in moving towards the creation of a National Park in the Gatineau Hills.

The actions of farmers in the Kingsmere-Camp Fortune area, who logged the forests near their homes for firewood, spurred on the issue of protecting the Gatineau forests. The 1931 OSC map depicts several cleared areas of farmer's fields. When the depression struck in the early 1930s, farmers turned to their woodlots as a source of income, and noticeable sections of clear cut roused an affluent and influential cottage community into action. The local logging enterprises in the hills alarmed those who sought the forests of the Gatineau Hills for their aesthetic value, and action was quickly taken to protect the trees. ${ }^{99}$ In 1933 the OSC created the Ottawa Ski Club Forest Preservation Society to raise money to buy additional land around Camp Fortune to protect the forest around Camp Fortune. In the "OSC News" of December 1933, George McHugh, president of the Forest Preservation Society wrote: "We do object to the complete clearing of whose $[\mathrm{sic}]$ where no attempt is made to save the saplings and undersized growth so that the soil and moisture may be preserved and the forest growth eventually re-established." ${ }^{100}$ McHugh advocated the expropriation of land as far as

(Ottawa: 1903). Edward H. Bennett, Report of the Federal Plan Commission for the Cities of Ottawa and the Hull (Ottawa: 1915). Noulan Cauchon, Federal District Plan (Ottawa: 1922).

98 LAC, RG 34, vol. 265, letter from Federal Woodlands League, March 6, 1937. In Alisa Catherine Apostle, "The View from the Hill: National Park Culture and Gatineau Park 1920-1960," (MA thesis, Queen's University, 1997), 82. http://www.collectionscanada.gc.ca/obj/s4/f2/dsk3/ftp05/mq20602.pdf (accessed 24 February 2014).

99 Dennis Messier, "Gatineau Hills Forest Industry 1800 to 1938: Myth or Reality?” Gatineau Park Chronicles (Ottawa: National Capital Commission, Fall 2007). http://gvhs.ca/digital/gatineaupark/chronicles/forest.html (accessed 24 February 2014).

100 “The Ottawa Ski Club News,” No. 1 (December, 1933). http://gvhs.ca/digital/gatineau-park/osc/193303-09.pdf (accessed 11 February 2014). 
Masham Road for a national park, and encouraged OSC members to join the society. In 1934, the OSC efforts led to the creation of a Federal Woodlands Preservation League. ${ }^{101}$ The League represented the interests of wealthier cottagers and landowners, as well as the OSC, and it was their influence on the FDC that eventually led to the first land purchases in the Gatineau Hills for the creation of a park and scenic automobile parkway to contribute to the beautification of the National Capital Region. ${ }^{102}$ The League included OSC members like Mortureux and was lead for a number of years by Meech Lake cottage owner Roderick Percy Sparks, with the Governor General and Prime Minister King as patrons, and R.B. Bennett, and Sir Robert Borden as honorary members. Their primary goal was 'protecting' the forests from logging to maintain their aesthetic appeal. $^{103}$

The call for the protection of the scenic values appreciated by wealthy cottagers was not unique to the Gatineau Hills. Ellen Stroud showed that the interests of cottagers were at the root of forest protection throughout the northeastern United States in the late nineteenth and early twentieth centuries. Cottagers at Lake Sunapee in Maine, for example, were influential enough to elicit legislative support for the protection of the forests making up the "viewshed" they enjoyed from their cottages. Local farmers"

\footnotetext{
101 Fletcher, Historical Walks, 59; Filion and Gagnon, The Creation and Early Development of Gatineau Park, 13; "Ottawa Ski Club News," No.2, (January 3, 1934), 4. http://gvhs.ca/digital/gatineaupark/osc/1934-01-03.pdf ( accessed 4 March 2014). Fletcher credits the OSC with being instrumental in the creation of the League, and Gagnon agrees.

102 Apostle, "The View from the Hill: National Park Culture and Gatineau Park 1920-1960." 77-78. Apostle argued that the Gatineau Hills became viewed "as an unproblematic natural expanse" to be "transformed and 'preserved' into a suitably complementary space to the district capital."

103 King, "The Diaries of Prime Minister William Lyon Mackenzie King," (September 20, 1933), 263. https://www.collectionscanada.gc.ca/databases/king/001059-119.02e.php?\&page id nbr=14486\&interval=20\&\&PHPSESSID=req3eoice06evalougrvgukel2 (accessed 11 February 2014).
} 
logging compromised the forests' aesthetic appeal, so the cottage community purchased the land and banned logging. ${ }^{104}$

Roderick Percy Sparks pressed on behalf of the Federal Woodlands Preservation League, for an extensive mapping and inventory program of the forests of the Gatineau Hills. Sparks lobbied the Minister of the Interior until the Lower Gatineau Woodlands Survey of the lands bordering Mountain Road, Mine Road, and Meech Lake Road was completed in an effort to protect the area's forests from clearcutting. ${ }^{105}$ The League proposed managing the logging enterprises to 'improve' the forests, rather than banning logging to protect them. In 1937, the Federal Woodlands League wrote to the FDC. "The purchase of 1,000 acres of the mountainous area at an estimated cost of $\$ 10.00$ per acre, this area to be improved by silvaculture operations." "On this basis there would be an annual return of $5 \%$ on the outlay of say $\$ 12,000$ for the purchase of the land." ${ }^{" 106}$ King was sympathetic to the idea of preserving the region's natural beauty by expropriating land in the Gatineau Hills, but initially refrained from taking decisive action as Prime Minister because his property at Kingsmere elicited speculation that the proposed park was a self-serving attempt to bolster his estate. ${ }^{107}$

In 1938. the Federal Woodlands Preservation League's effort to manage the deforestation of the Gatineau Hills led to the first land purchases when the King government passed a budget of $\$ 100,000$ for the purchase of land for a National Parkway.

\footnotetext{
104 Ellen Stroud, Nature Next Door, 57.

105 Filion and Gagnon, The Creation and Early Development of Gatineau Park, 16.

106LAC, RG 34, vol. 265, letter from Federal Woodlands League, March 6, 1937. Cited in Alisa Catherine Apostle, "The View from the Hill: National Park Culture and Gatineau Park 1920-1960," 81.

${ }^{107}$ King, "The Diaries of Prime Minister William Lyon Mackenzie King," (December 20, 1937), 1148. https://www.collectionscanada.gc.ca/databases/king/001059-119.02e.php?\&page id nbr=18590\&interval=20\&\&PHPSESSID=9og8tru5dmdgiutnbe0argrhr3 (accessed 11 February 2014).
} 
The FDC was the branch of the government responsible for managing the park and improving its recreational facilities. The history of the early land acquisition for the construction of a parkway and the protection of forests as parkland is a complicated patchwork of FDC land purchases and expropriation undertaken on a piecemeal basis, with 5,000 acres purchased in 1938. It was not until 1952, after King bequeathed his estate to the Government of Canada, that the land was consolidated as a park in the Kingsmere Park Act. ${ }^{108}$ Alisa Apostle's MA thesis “The View From the Hill: National Park Culture and Gatineau Park 1920-1960," explores the FDC's expropriations, the Federal Woodlands Preservation League, and the Lower Gatineau Woodlands Survey in greater detail. ${ }^{109}$ Deciphering the complicated history of Gatineau Park and the FDC's land purchases is not the goal of this work, as the establishment of park boundaries came well after the OSC was established in the Kingsmere-Camp Fortune area outlined by the 1931 OSC trail map. The FDC's role in changing the landscape by improving roads, parking lots, and promoting recreation in Gatineau Park alongside the OSC is, however, important to this history.

On the ground, the first major undertaking of the Commission that put them in contact with the hills and rocks of the Kingsmere-Camp Fortune area was the construction of a hiking trail offering scenic views of the Gatineau Hills for park patrons. Named the Skyline Trail, it started near the intersection of the Canyon Trail and Little Switzerland, at the top of the first climb up Ridge Road from Kingsmere (Figure 3). Built as a hiking trail for summer, the trail served equally well as a ski trail in winter. A major difference in the construction of a hiking trail like the Skyline is that it does not cross any

\footnotetext{
108 NCC, Gatineau Park Master Plan (Ottawa: NCC, March 1990), 29-33.

109 Apostle, "The View from the Hill: National Park Culture and Gatineau Park 1920-1960."
} 
low-lying areas, swamps, or ponds, which are impassable when water is not frozen. The FDC's involvement in the development of the Gatineau Hills increased automobile accessibility year round, with improved snow removal services and summer maintenance. In part thanks to the improvements brought by the FDC, OSC membership experienced resurgence after suffering a lull during the depression. With more skiers visiting Camp Fortune more easily, and increased public knowledge of the park, there was a need to grow infrastructure, and modernize the ski facilities to keep up with the rapidly evolving sport.

Until 1942, skiers were forced to climb to the top of hills under their own power, either by taking trails like Merry-Go-Round, the Highland, or Frank's Trail, which placed hills and climbs in succession, or by climbing up and then descending cleared slopes like the Joe Morin Slalom, or Corkscrew Hill several times. This made the sport very physically demanding, and restricted hill skiing to only the most dedicated individuals. In 1942, John P. Taylor, Hubert Douglas, and John Carscadden constructed the first rope tow in the region on the Slalom Hill at Camp Fortune. The tow featured a gasolinepowered motor that turned a wheel, which pulled a rope through two pulleys, one at the top and the other at the bottom of the hill. The rudimentary contraption pulled skiers to the top of the hill when they grabbed hold of the rope. ${ }^{110}$ Although using early rope tows required a certain level of upper body strength and coordination, it was much faster and far less strenuous than climbing by ski. Skiers could now focus even more of their time, energy, and enthusiasm on mastering the art of controlled descents and practicing contemporary technique. The 1942 Ottawa Ski Club Handbook identified the three

\footnotetext{
${ }^{110}$ Elliott Kaufmann and John A. Stevens, White Gold: The John Clifford Story (Renfrew: General Store Publishing House, 1993), 32.
} 
necessary maneuvers for safe hill skiing to be the "snow plough," "tail wag," and the "jump turn."111 Emphasizing downhill skiing and using the rope-tows was referred to condescendingly as "yo-yo skiing" by some members of the old guard, despite its rapidly growing popularity. ${ }^{112}$

In the years following the installation of the first rope tow, a cleavage between trail and hill skiers began to form on the trails and slopes of the Gatineau Hills; the growing spatial division in the sport that was echoed by members of the OSC in the club's publications. Improved access to Camp Fortune, with new parking lots and more direct bus service to Dunlop's and the Mountain Lodge on Kingsmere Road, crowded the popular Slalom slope. The 1942 enlargement of the parking lot at the bottom of Dunlop's Road by the FDC more than tripled the capacity for parking there from 75 to 300 cars, less than 2 kilometers from the foot of the rope tow. ${ }^{113}$

The increased traffic on the slopes affected the condition of the snow of the ski surface. When heavily used, even a carefully cross-checked hill developed bumps and ruts, making it more dangerous and less enjoyable. The growing surface area requiring cross-checking by the Night Riders demanded more of their limited time, and issues of maintenance on the trail network started coming into play. Time spent by the Night Riders checking the Slalom Hill diverted them from setting tracks and cross-checking hills on popular trails like the Highland, George's, the Merry-Go-Round, and Frank's. Some skiers were skeptical of the shift towards a more centralized discipline of skiing

\footnotetext{
111 Charles Mortureux, "How to Control One's Skis on the Trail," Ottawa Ski Club Handbook (Ottawa: Ottawa Ski Club Publication, 1942), 31. http://gvhs.ca/digital/gatineau-park/osc/1942-OSC-Handbook.pdf (accessed 11 February 2014).

112 Arnold Midgley, interview by author, September 25, 2013, Gatineau, QC, digital recording. 113 James S. Patrick, "Camp Fortune: Ways of Access - Hills and Trails," Ottawa Ski Club Guide 1943 (Ottawa: Ottawa Ski Club Publication, 1943), 16. http://gvhs.ca/digital/gatineau-park/osc/1943-OSCGuide.pdf (accessed 24 February 2014).
} 
centered around rope tows and speed and voiced their opposition to the emerging discipline of hill skiing. Even the former President of the OSC, Mortureux, was openly critical of the developments of hill skiing in the 1940s. "We are entering the ski tow age. Decidedly a sign of the degeneracy of the times, and not to be commended. However, if these contrivances fail to attract patrons, the operators will have plenty of rope to hang themselves with."114 Mortureux's feelings towards those who strictly practiced hill skiing at Camp Fortune would be reiterated by "oldtimers" for years to come.

Following the Second World War, the Ottawa Ski Club experienced considerable and rapid growth in its membership as a result of factors both internal and external to skiing. The population of Ottawa had grown to 165,000 due to the expanding public service. ${ }^{115}$ Also, ski technology in general was improving, and local retailers offered package deals and marketed increasingly sophisticated products to men and women. ${ }^{116}$ The consolidation of trails, hills, lodges, and concessions at Camp Fortune by the OSC continued in earnest as the area began the final transformation from rest spot for skiers to a local destination for modern 'alpine' skiing. In 1945, congestion on the Joe Morin Slalom Hill required it to be widened to accommodate the increased traffic the rope tow attracted.

\footnotetext{
114 “Editorial Comments," Ottawa Ski Club Yearbook 1945-46 (Ottawa: Ottawa Ski Club Publication, 1946), 3. http://gvhs.ca/digital/gatineau-park/osc/1945-1946-year-book.pdf (accessed 11 February 2014). ${ }^{115}$ R. Gustave Lanctot, "History of the National Capital," Plan For the National Capital General Report (Ottawa: Federal District Commission, 1950), 42. https://qshare.queensu.ca/Users01/gordond/planningcanadascapital/greber1950/history.htm (accessed 11 February 2014); Michael MacConaill, interview by author, November 13, 2013, Gatineau, QC, digital recording.

116 Dover's Hardware, Sporting Goods advertised a complete ski package of skis, boots, bindings, and poles for \$14.95. Ottawa Ski Club Yearbook 1945-46 (Ottawa: Ottawa Ski Club Publication, 1946), 22. http://gvhs.ca/digital/gatineau-park/osc/1945-1946-year-book.pdf (accessed 24 February 2014). Depictions of women clad in the latest ski "togs" graced the pages of almost every issue of the Ottawa Ski Club Yearbook.
} 
As hill skiing became more popular and enthusiasts developed a preference for the purpose-built slopes and rope tows being expanded at Camp Fortune, the OSC executive was faced with more complex managerial tasks. Choosing to concentrate their resources on the construction and maintenance of trails, hills, and lodges, the club contracted out the operation of the cafeteria at Fortune lodge and the rope tow to John Clifford in the winter of 1945-46. ${ }^{117}$ Clifford, a former Night Rider and competitive downhill ski racer, was a visionary for alpine skiing in Canada. He recognized early on the importance of offering lift access skiing to the large population in Ottawa, who could now drive their cars or take the bus to the expanded parking lot at the base of Dunlop Road. With the help of his "right hand man" Steve Saunders, an experienced welder and good friend of Clifford's, he began engineering the transformation of skiing in the Gatineau Hills. Annual trips to the northeastern United States, where downhill ski areas catered directly to large urban populations, inspired Clifford and Saunders to develop Camp Fortune, still in its infancy as a ski hill, into a modern alpine ski location. ${ }^{118}$

117 Kaufmann and Stevens, White Gold, 32.

118 David Midgley, interview by the author, November 12, 2013, Gatineau, QC, digital recording. 


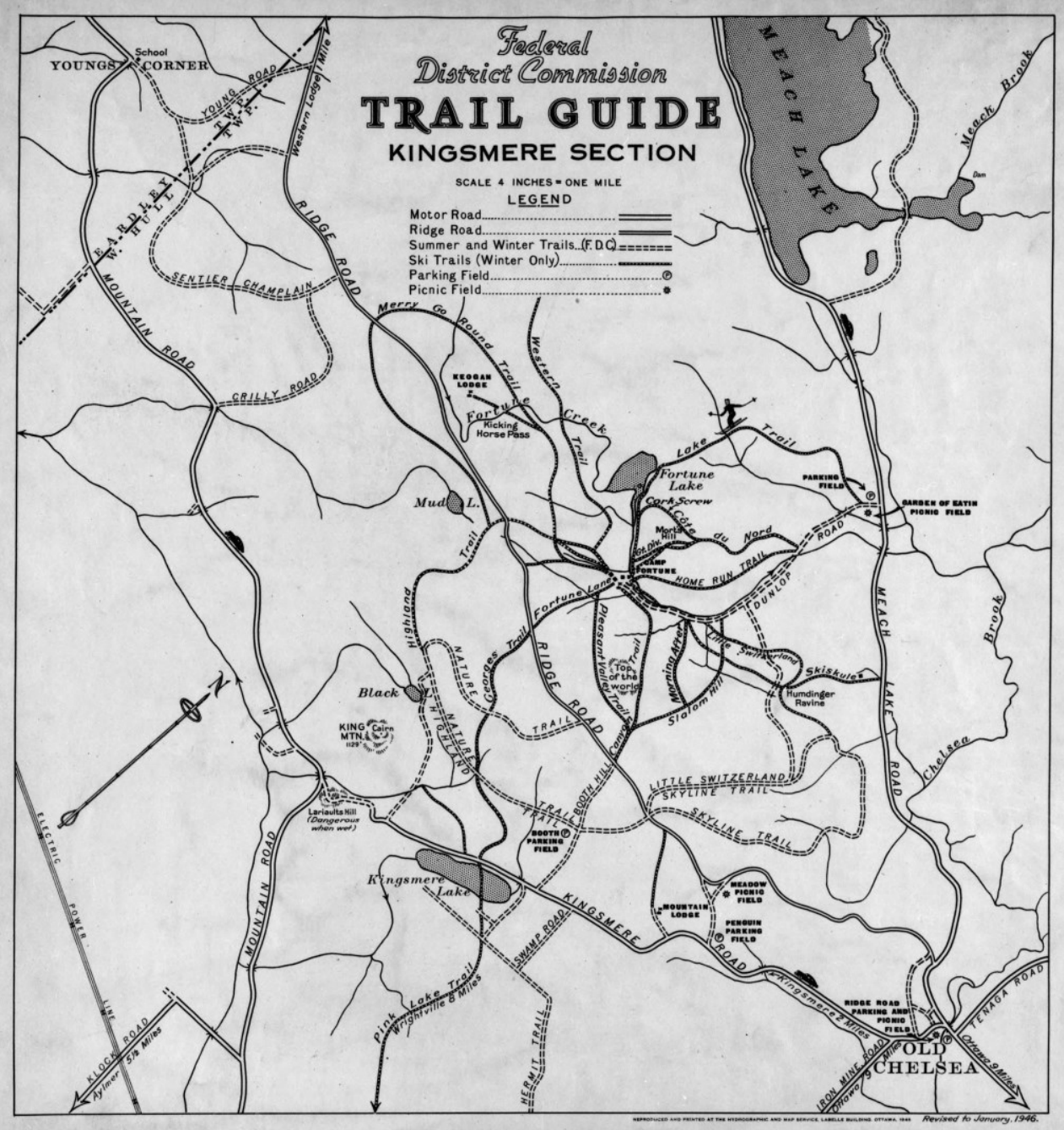

Figure 5: Federal District Commission Trail Guide: Kingsmere Section, 1946.

The FDC published a recreational Trail Guide for Gatineau Park in 1946 (Figure 5).

The map shows a similar section of the Gatineau Hills to the 1931 OSC map, but on a different orientation, and the commission's map omits a great deal of the vernacular present in the older map. Some sections of trail do not appear on the 1946 map; it ascribed new names to some trails and omitted the names of others. The map also erroneously indicated the Highland, Little Switzerland, and the Nature Trail as yearround trails, rather than ski-only. This may not appear problematic, but these trails 
frequently navigated low-lying areas, bogs, and even large ponds, which would be frozen in winter, when the trails was intended for use. Inexperienced hikers using the trails unintentionally widened them by avoiding wet spots. ${ }^{119}$

In 1931, the OSC members who made their map outlined the property surrounding Camp Fortune to make the distinction between OSC land and the Gatineau Hills clear. The delimitations of park space shown on the 1931 map, however, existed only on paper. Skiers on the trail network were oblivious to the imaginary property lines they inevitably transgressed on any number of trails. George's Trail, Highland, Little Switzerland, Merry-Go-Round, the Canyon Trail, and Ridge Road all cross the invisible boundary between club and non-club land. The mapping projects of the FDC issued a "vastly simplified and uniform" depiction of the trail network (Figure 5), consisting of a grid of smoothed curving lines connecting points of interest and parking lots to one another in an area bereft of property lines and topography. ${ }^{120}$ On the map, Gatineau Park appeared as homogeneous space despite the existence of private lots not yet expropriated by the FDC, and the privately owned lands of the OSC. ${ }^{121}$

The FDC's portrayal of the Kingsmere-Camp Fortune recreational area as public parkland was one of the reasons the club continuously urged members to pay their annual fees and to display the OSC membership badge in plain sight. Membership fees and day

\footnotetext{
119 I have skied, hiked, and mountain biked these trails, and in summer there are numerous areas, especially in spring that are impassable without straying from the trail.

120 James C. Scott, Seeing Like a State: How Certain Schemes to Improve the Human Condition Have Failed (New Haven and London: Yale University Press, 1998), 34-35. Scott was referring to the modern states need for "vastly simplified and uniform property regime." Although the FDC map of 1946 did not catalogue property for the use of the state, it did present the same type of modern spatial organization. Scott's theory can be applied to many situations, but I feel it works well for this particular map.

${ }^{121}$ Filion and Gagnon, The Creation and Early Development of Gatineau Park, 16.
} 
passes for the lodges and trails were the bulk of club revenue. ${ }^{122}$ Badges were cloth patches and club publications hounded members to sew them onto their ski pants. Guest passes were available and could be paid upon entering one of the lodges. Volunteer "Checkers" inspected badges and guest passes when skiers entered Fortune Lodge, which they reached over trail from parking lots at Dunlop's and Kingsmere; there was no inspection of membership at the trailhead or in the parking lots. ${ }^{123}$ The 1946 FDC map validated Gatineau Park recreational experience as one of free movement along the trail network. This perception of the space as purely public was something the OSC contended with as skiers used their facilities without paying.

The momentous rise in the popularity of hill skiing following the Second World War forced the OSC to adapt quickly to the sport's growing popularity, and accommodate the increasing penchant towards hill skiing and rope tows. Although older members and many members of the club's executive remained devout trail skiers, they recognized the direction in which the sport was going and restructured accordingly. The Night Riders' mandate became entirely concentrated on the development and maintenance of hill skiing at Camp Fortune, filling in holes and removing rocks from the slopes during the summer to facilitate the winter's work which now emphasized maintaining a consistent sliding surface. The trail network required the same amount of maintenance as in previous years, but the pull of hill skiing's popularity channeled club resources towards Camp Fortune. By this time, some trails had already fallen into

122 "Financial Info for Ottawa Ski Club Inc." Ottawa Ski Club Yearbook 1947-48 (Ottawa: Ottawa Ski Club Publication, 1948), 77. http://gvhs.ca/digital/gatineau-park/osc/1947-1948-year-book.pdf (accessed 11 February 2014). The club revenues for the winter of $1946-47$ were posted here, showing $\$ 8,142.00$ in annual membership fee revenue, $\$ 1565.00$ in guest fees paid by one day visitors to the lodges, and $\$ 200.00$ in ski tow revenue paid to them by John Clifford.

123 Elmer Cassel, “The Checker Talks Back," Ottawa Ski Club Yearbook 1947-48, 26.

http://gvhs.ca/digital/gatineau-park/osc/1947-1948-year-book.pdf (accessed 11 February 2014). 
disrepair and the pinnacle of the trail network in the Kingsmere-Camp Fortune area had passed.

Nationalism and the larger promotion of wilderness recreation in North America as well as the intent to create a wilderness preserve for the National Capital Region appear to have led to the creation of Gatineau Park as a political entity. ${ }^{124}$ It was the recreational infrastructure of a growing ski population, already well established in the KingsmereCamp Fortune area that allowed the general public to take advantage of the hills for recreation. The trail network built by the OSC for its membership allowed visitors to explore and experience the area and became integrated into FDC promotion of Gatineau Park in the 1946 map. In the following years, the space of the Kingsmere-Camp Fortune area became divided according to the spatial needs of an increasingly sophisticated sports culture of skiing.

124 Apostle, "The View from the Hill: National Park Culture and Gatineau Park 1920-1960.” 


\section{Chapter Two: Division in Skiing and the Rope Tow Age of Gatineau Park, 1947- 1956}

On a Sunday morning in winter of 1947, two young Ottawa Ski Club members and brothers, Arnold and David Midgley, took the Gatineau Bus from downtown Ottawa to the Gatineau Hills for a day of skiing. The boys were infatuated with the new style of skiing available on the wide slopes of Camp Fortune, where mechanical rope tows alleviated the need to climb up in order to slide down. The boys' OSC memberships granted them access to the best skiing surfaces in Gatineau Park. To reach Camp Fortune, they disembarked from the bus at Lemay's Restaurant on Kingsmere Road, next to the Mountain Lodge, alongside other skiers and fellow OSC members, most of whom were bound for the valley at the center of the sprawling network of ski trails. The rope tows in the sheltered valley of Camp Fortune were increasingly popular, and were part of the reason skiers gravitated there more than any other area of Gatineau Park during winter. Rope tows removed the demanding task of climbing, allowing skiers to spend more time sliding downhill then ever before and making the sport less physically taxing. Alpine skiing was becoming increasingly popular in Canada, as ski hills in the Canadian Rocky Mountains of British Columbia and Alberta springing up to take advantage of the a postwar boom in alpine skiing. ${ }^{125}$

Camp Fortune was not the only place that offered rope tows in the area. Local resident Eddy Quipp took advantage of his property's location next to the bus stop at Lemay's and operated his own tow into the Kingsmere-Camp Fortune network. Quipp sold tickets for a ride up the hill at a small fee. ${ }^{126}$ The tow pulled skiers to the height of

\footnotetext{
125 Chic Scott, Powder Pioneers: Ski Stories from the Canadian Rockies and Columbia Mountains (Vancouver: Rocky Mountain Books, 2005), 102.

126 Arnold Midgley, interview by author, September 25, 2013, Gatineau, QC, digital recording.
} 
the land where Frank's Trail, Little Switzerland, and the Ridge Road converged near Wattsford's Lookout (see Figure 7). From there, the ski to Camp Fortune involved more sliding than climbing, and skiers bound for the trails beyond Fortune saved energy for the rest of their trip by using the tow. The Midgleys could not afford to purchase tickets for Quipp's rope tow, so they climbed up the hill under their own power, on a trail named Excelsior next to the rope. Once they reached the top, a brief push to the northwest took them to the Top Of the World, from where they skied down one of the wider trails into Camp Fortune.

The trails leading most directly into the valley from the Ridge Road were the Canyon Trail, Pleasant Valley, and Fortune Lane. These trails were wider than most others and entirely downhill, allowing skiers to warm up and practice their turns before reaching the even broader sliding surfaces at Camp Fortune. ${ }^{127}$ For Fortune-bound skiers who preferred the more horizontal pleasures of trail skiing, the Skyline and Little Switzerland trails took more circuitous routes to Camp Fortune, but would still have them in the valley in time for lunch. Once in the valley, skiers interested in exploring further could take the Long Merry-Go-Round loop or the Western Trail into the less traveled western section of the network. Enthusiastic hill skiers like David Midgley, a high school student at the Glebe Collegiate Institute who earned his OSC membership badge as a volunteer with the Night Riders, and Arnold, who paid a reduced junior fee, had unlimited access to the rope tows provided by the club at Camp Fortune. Access to rope tows and manually groomed hills attracted many skiers and made the valley a destination for a day's skiing, rather than just a place to visit Fortune Lodge.

127 Arnold Midgley, interview by author, September 25, 2013, Gatineau, QC, digital recording. 


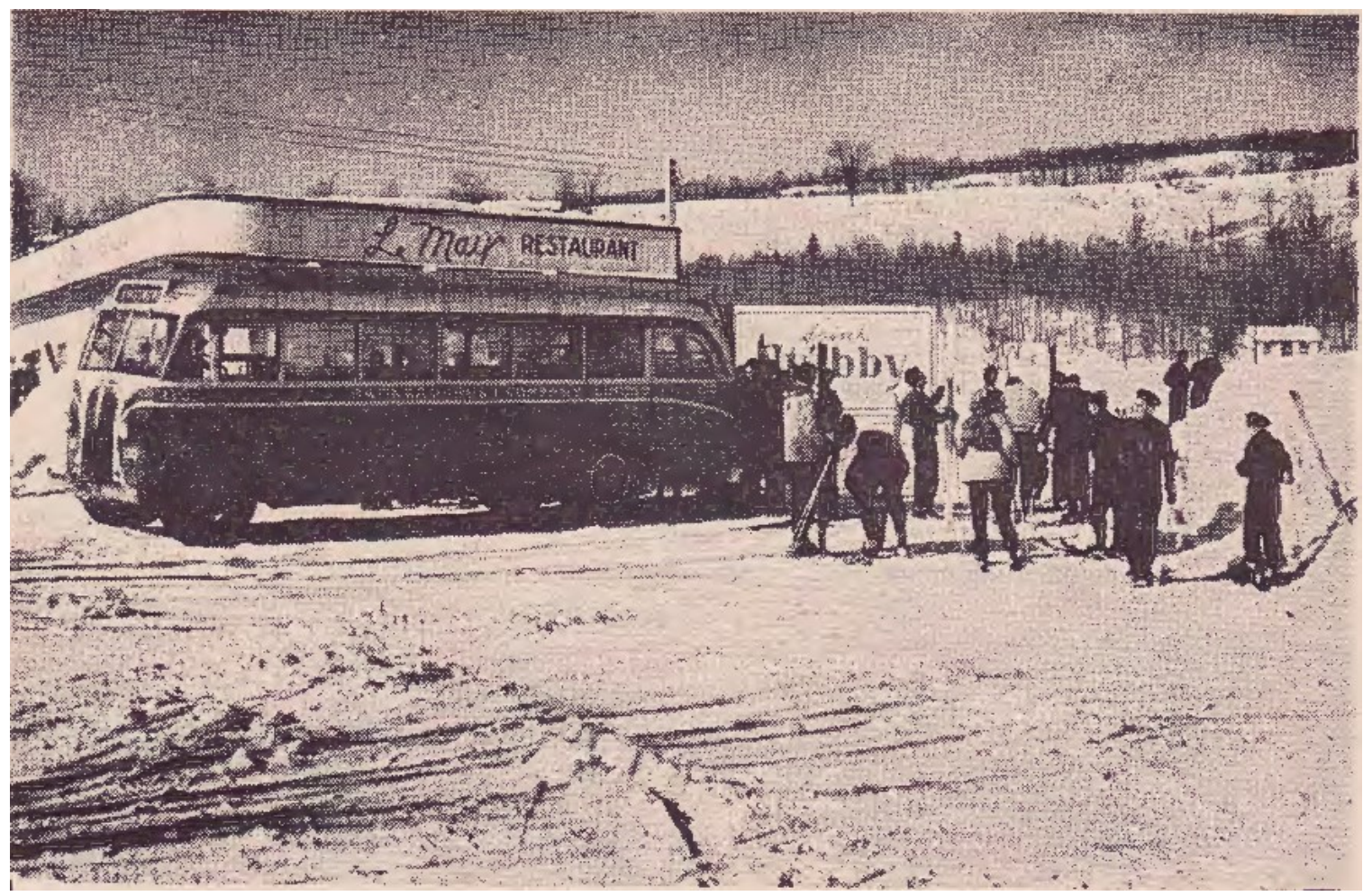

Figure 6: This photo shows the Gatineau Bus dropping off skiers at Lemay's Restaurant on Kingsmere Road. Although Eddy Quipp's rope tow is not visible, the cleared field on the hill in the background was likely Quipp's property. This photo was featured in an advertisement for the Gatineau Bus, on page 58 of the Ottawa Ski Club Yearbook 194748 .

On Sunday mornings the Canyon Trail and Fortune Lane acted as one-way arteries for Camp Fortune bound skiers coming from the eastern entrances to the trail network from the parking lots at Booth Hill, Penguin, and Lemay's on Kingsmere Road. Although the unidirectional nature of the trails leading to Camp Fortune on Sunday mornings was not indicated on the map or on the trail, droves of people heading from Kingsmere made the flow of traffic clear, and club members were made aware of this in OSC publications. ${ }^{128}$ In 1947, skiers arriving from Kingsmere moved freely between the cross-country trail network and the hills of Camp Fortune. The spaces of hills and trails

128 James S. Patrick, "Editorial," Ottawa Ski Club Yearbook 1950-51 (Ottawa: Ottawa Ski Club Publication, 1951), 8. http://gvhs.ca/digital/gatineau-park/osc/1950-1951-year-book.pdf (accessed 11 February 2014). 
were not yet divided into the distinct societies of hill and trail skiers. Even skiers like the Midgleys, who preferred hill skiing, had to cover some ground along the trails before reaching the developing hill skiing infrastructure at Camp Fortune.

Kingsmere was not the only popular point of entry to Gatineau Park. Skiers could also take Gatineau Bus service to Old Chelsea, where the start of the Canyon Trail was only a few hundred meters west of town on Meech Road. Despite the relentless climb up the Canyon to Wattsford's Lookout, it remained a popular route for skiers who enjoyed the endurance aspect of cross-country skiing. Entering the trail network from Kingsmere or Old Chelsea offered a choice of routes for those bound for the OSC's principal ski area at Fortune. The entrances' distance from the valley made some amount of climbing inevitable, even from Quipp's rope tow. Direct access by car or bus to downhill specific skiing at Camp Fortune was not yet available. As David Midgley said of skiers taking up the sport in this period "We all started off as trail skiers."129

For the purpose of simplicity, in this chapter, skiers whose primary goal in Gatineau Park was to ski at Camp Fortune will be referred to as 'hill' or 'alpine' skiers, and those who preferred skiing the trails, 'trail' or 'cross-country' skiers. Although social and spatial divisions between these groups were not yet fully formed in the winter of 1946-47, as the OSC reorganized Gatineau Park space to favour the development of hill skiing at Camp Fortune differences within the ski community began wedging the two groups apart. Keen trail skiers coming from the east entrances, especially Kingsmere, were likely to avoid Fortune entirely because it was too close to the start of a trip to warrant a rest, and the lodges were often overcrowded. There was also the physical

129 David Midgley, interview by author, November 12, 2013, Gatineau, QC, digital recording. 
obstacle of negotiating the trails leading into the valley, which were too steep for some self-proclaimed "oldtimers" who preferred a less precipitous grade. ${ }^{130}$

Proud trail skiers like OSC member D.L. Surveyor voiced their opposition to the growing hill skiing culture at the epicenter of the trail network. "We shun Fortune as we would the plague. All those noisy youngsters drinking pop, eating candy bars, slamming doors, crowding tables - and fireplaces! It's altogether too much. Besides, to get down there it is necessary to slide down some rather steep hills and we, thank God, have never learned controlled skiing nor do we have this new contraption - steel edges." 131 Surveyor's lament demonstrated the developing division between trail and hill skiers, and exposed the levels on which the separation existed. Surveyor, and other self-proclaimed "old-timers" associated the boisterous and chaotic atmosphere of Fortune Lodge with over -stimulated "youngsters." In the mind of Surveyor, trail skiers were mature and solemn. Their lodge experience was one of refuge, relaxation, and serious discussion of club affairs, trees, and the problems of the world. ${ }^{132}$ When their philosophical conversations returned to skiing, they told tales of meeting other skiers, encountering wildlife, or simply enjoying nature. The trail skiing experience and the lodge dialect emphasized being outdoors and getting a feeling of adventure; ski technique and improvements in equipment technology were not a popular subject, nor was speed. ${ }^{133}$ Trail skiing lacked much of the technical vocabulary that filled the cafeteria of Fortune Lodge. Alpine skiers discussed the intricacies of technique and carrying speed, but they also described and reacted to hill conditions in great detail, referring to specific

130 D.L. Surveyor, "Our Day,” Ottawa Ski Club Yearbook 1946-47, 54. http://gvhs.ca/digital/gatineaupark/osc/1946-1947-year-book.pdf (accessed 11 February 2014).

131 D.L. Surveyor, "Our Day,” Ottawa Ski Club Yearbook 1946-47, 54. Emphasis in original.

132 D.L. Surveyor, "Our Day,” Ottawa Ski Club Yearbook 1946-47, 54. Emphasis in original.

133 Michael MacConaill, interview by author, November 13, 2013, Gatineau, QC, digital recording. 
bumps, ice patches, and exposed rocks they had committed to memory. ${ }^{134}$ The limited space of Camp Fortune's slopes allowed for these conversations to use visual cues embedded in the minds of skiers who repeatedly engaged with the terrain over the course of a day, and over several days in a single season. The monocultural sportscape of downhill skiing bound conversation between alpine skiers to the limited, yet stimulating, experience of controlled descents at maximum speed. ${ }^{135}$ The minutia of executing turns, issues of edge control, weight transfer techniques, carrying momentum, and the animated recounting of the thrills elicited by these bodily experiences dominated lodge conversation among the competitive alpine crowd. ${ }^{136}$ Serious hill skiers possessed intimate knowledge of the alpine surfaces of Mort's, Slalom, and the Morning After runs, and if conditions deteriorated or were not satisfactory, they were quickly scrutinized. ${ }^{137}$

Applying German sociologist Henning Eichberg's sports "trialectic," and geographer John Bale's adaptation of the concept to the disciplines of skiing in Gatineau Park helps explain the divergence between trail and hill skiing during the postwar period as one rooted in the different spatial requirements of individuals based on their approach to sport. Eichberg's "trialectics" of body culture emerged from the Danish approach to the sociology of sports as a cultural phenomenon. This represented a paradigm shift in how sports were studied. "Seeking the ways in which bodies - and landscapes - are configured is a means of recognizing diversity in what is often thought to be an increasingly homogeneous world." ${ }^{138}$ This approach to studying sports is used to show

\footnotetext{
134 Arnold Midgley, interview by author, September 25, 2013, Ottawa, ON, digital recording. 135 John Bale, Sports Geography, 137.

136 David Midgley, interview by author, November 15, 2013, Gatineau, QC, digital recording. 137 David Midgley, interview by author, November 15, 2013, Gatineau, QC, digital recording. 138 Eichberg, Body Cultures: Essays on sport, space and identity, 8.
} 
that skiers who interacted with Kingsmere-Camp Fortune space did so differently according to the 'body culture' of their sports experience.

Eichberg's methodology employs a pyramid model he calls the "body culture trialectic." The "trialectic" is composed of three "body cultures," each of the cultures is associated with a type of sports experience that structures the society of each group, and the type of space members' practice of the sport require and produce is identified. These body cultures are not hermetic, as "The real phenomena are neither clear in classification nor neatly 'trialectic,' but the categories and the methods of interpretation can - if in 'trialectic' form - produce new and critical insights." ${ }^{139}$ At the top of the pyramid, in the achievement sport scenario, competition is the catalyst for the development of superior technology, improving technique, and pushing individuals' physical limits in a competitive environment; serious ski racers fall into this category. To practice the sport at the highest level, an "achievement space" specifically designed for the sport is required, and new equipment technologies are embraced for advantages rewarded in competition, even if the advantages are marginal. ${ }^{140}$ In the postwar era, the hills at Camp Fortune became increasingly manicured to meet the needs of an emerging alpine racing culture that embraced modern ski equipment and practices. ${ }^{141}$

In the bottom left of the "trialectic" is the fitness sport category; the largest portion of recreational skiers fall into this group. Eichberg argues that fitness sport participants value health and well-being, and technological advantages are less important because serious competition does not incentivize performance to the same extent as in

\footnotetext{
139 Eichberg, Body Cultures, 123.

140 Eichberg, Body Cultures, 7-9.

141 Andrew Denning, "From Sublime Landscapes to 'White Gold': How Skiing Transformed the Alps after 1930," 82. Denning explained how the phenomenon of hill skiing drastically transformed the European Alps during the postwar period, and referred to Eichberg and Bale's use of the trialectic.
} 
achievement sports. Instead of seeking to maximize performance and efficiency, members of a fitness sport reach a consensual 'center' where the group embraces a technology that allows them to practice their sport. ${ }^{142}$ Michael MacConaill validated trail skiers in Gatineau Park's relationship with technology as typical of Eichberg's fitness sport scenario. When asked about how important equipment was to he and his fellow recreational trail skiers, MacConaill recalled: “we didn't talk about it too much, we sort of decided on what worked for us and went with it." ${ }^{, 143}$ In the recreational space of the cross-country trail network the core of a small community demonstrated the social and technological attributes of a fitness sport body culture.

The third body culture is the body experience and social sensuality. This scenario is less applicable as Eichberg explains it, because they perform their sport "in nearest proximity to daily life." Things like playing catch in a backyard, running around the block, or dancing in a local park fall into the body experience scenario. Because the vast majority of skiers lived some distance from Gatineau Park, it was not possible for them to engage with the space as one "in nearest proximity to daily life." Eichberg's "trialectic," however, was also applied as a tool of critical analysis for the Association of Danish Communities. Using the "trialectic" to study society through sport, or sport through society, the societal application of the body experience and social sensuality scenario is more revealing of this section of ski culture in the Gatineau Hills. The decentralized society of skiers who skied infrequently or experimented by trying the sport on borrowed equipment combines plural lifestyles similar to those in the fitness sport scenario, but the pressure for consensus is less important because participation is less consistent.

\footnotetext{
142 Eichberg, Body Cultures, 125.

143 Michael MacConaill, interview by author, November 13, 2013, Gatineau, QC, digital recording.
} 
Individuals value family, neighbourhood, and quality of life in an "experiential space" where participants seek new waves of body culture, without becoming attached to the sport through a club or association, as in the other two sport scenarios. ${ }^{144}$

Eichberg has received increasing attention from Anglo American scholars. In 2003, John Bale published the second edition of Sports Geography, which included an adaptation of Eichberg's "trialectic" in a way that emphasized how the three body cultures "require and produce different kinds of bodies and different kinds of places and spaces." Bale's work included examples of the "sportscapes" produced by body cultures. ${ }^{145}$ In Gatineau Park space, trail skiers who intentionally avoided the heavily altered landscape optimized for hill skiing at Camp Fortune did so because the body culture of their sport had different spatial requirements. Applying the "trialectic" in depth shows that the division within the OSC that emerged in the postwar period was rooted in the spatial relationships Bale emphasized in his adaptation. ${ }^{146}$

Although cross-country skiing participation waned in the postwar period as hill skiing's modern experience attracted a growing constituency, the experience of the small trail skiing community is essential in understanding how Gatineau Park space became categorized according to different body cultures, embodied by the two distinct types of skiing shaping the space. Trail skiers prioritized the health benefits provided by the physical act of moving through park space under their own power without mechanical assistance because it was thought of as "excellent training." 147 As the sport slowly

\footnotetext{
144 Eichberg, Body Cultures, 7-9.

145 Bale, Sports Geography, 8-9.

146 Bale, Sports Geography, 9.

147 Herbert Marshall, “A Message From the President,” Ottawa Ski Club Yearbook 1949-50 (Ottawa:

Ottawa Ski Club Publication, 1950), 13. http://gvhs.ca/digital/gatineau-park/osc/1949-1950-year-book.pdf
} 
established itself as different from hill skiing, and, conversely, hill skiing set itself apart, group consensus on proper equipment, technique, and ideal trail designs created a cooperative social structure. ${ }^{148}$ OSC publications advertised and suggested norms for equipment, clothing, waxing techniques, recommended routes, and outlined trail maintenance expectations with photographs and columns aimed at trail skiers. ${ }^{149}$ For vocal members of the OSC trail community, their time spent in park space combined physical and social-psychological well-being. ${ }^{150}$

Members of the OSC cross-country community also pursued outdoor recreation for the dialogical and experiential relationship in the social space it offered. The discussions in quiet lodges among senior members of the trail skiing community, families skiing together on weekends to strengthen young and old bodies, and the positive effects of experiencing "the striking winter beauties of Gatineau Park" were all part of trailskiing culture. ${ }^{151}$ As they began establishing themselves as a distinct group in space adjacent to the galvanizing alpine community, trail skiers took steps to shape park space to suit their needs.

In 1947, a group of volunteer cross-country skiers formed the Trail Riders group to improve and maintain the recreational trail network of Gatineau Park. Trail skiers both

(accessed 19 February 2014). Marshall questioned the waning popularity of hill skiing and promoted its physical benefits.

148 Eichberg, Body Cultures, 124; Michael MacConaill, interview by author, November 13, 2013, Gatineau, QC, digital recording.

149 “Trail and Hill Etiquette," Ottawa Ski Club Yearbook 1947-48 (Ottawa: Ottawa Ski Club Publication, 1948), 22. http://gvhs.ca/digital/gatineau-park/osc/1947-1948-year-book.pdf (accessed 13 February 2014); J.A. Lewis, "The Secret Formula," Ottawa Ski Club Yearbook 1947-48, 39; W.S.L. "An Oldtimer Protests," Ottawa Ski Club Yearbook 1948-49 (Ottawa: Ottawa Ski Club Publication, 1949), 52.

http://gvhs.ca/digital/gatineau-park/osc/1948-1949-year-book.pdf (accessed 13 February 2014); James S. Patrick "Hills and Trails," Ottawa Ski Club Yearbook 1948-49, 80. http://gvhs.ca/digital/gatineaupark/osc/1948-1949-year-book.pdf (accessed 13 February 2014).

150 Eichberg, Body Cultures, 123.

151 Herbert Marshall, “A Message From the President,” Ottawa Ski Club Yearbook 1949-50, 13. http://gvhs.ca/digital/gatineau-park/osc/1949-1950-year-book.pdf (accessed 19 February 2014). 
required and produced the trail network that provided physical fitness, recreation, and served as a social space for their community. Members of the OSC who advocated trail skiing in club publications constantly referenced its physical and health benefits, as well as the social advantages of skiing. ${ }^{152}$

Doug Carman and OSC Secretary Sheila Hoare formed the Trail Riders in response to the neglect of the trail network by the Night Riders. With seventeen members on the original roster, they were responsible for maintaining the cross-country trail network. ${ }^{153}$ The growing maintenance needs at Camp Fortune had pulled the Night Riders away from the trails over the previous years, leaving many trails teetering on the point of abandon. The Night Riders' fall maintenance responsibilities previously included the removal of obstacles like fallen trees, collapsed bridges, and branches from most trails, but the intensive expansion of skiable hills at Camp Fortune took precedence. As Mortureux wrote in the Handbook, "Shrubs grow with amazing rapidity on the rich mould covering the rocks of the Gatineau Hills. Let a trail be neglected for the short

\footnotetext{
152 Herbert Marshall, "A Message from the President,” Ottawa Ski Yearbook 1948-49, 13. http://gvhs.ca/digital/gatineau-park/osc/1948-1949-year-book.pdf (accessed 13 February 2014); W.S.L., “An Oldtimer Protests," Ottawa Ski Club Yearbook 1948-49, 53. http://gvhs.ca/digital/gatineaupark/osc/1948-1949-year-book.pdf (accessed 13 February 2014); Charles J. Woodsworth "Skiing Today is All Downhill," Ottawa Ski Club Yearbook 1950-51, 43. http://gvhs.ca/digital/gatineau-park/osc/1950-1951year-book.pdf (accessed 11 February 2014); H.P. Douglas, "Memories," Ottawa Ski Club Yearbook 195051, 76. http://gvhs.ca/digital/gatineau-park/osc/1950-1951-year-book.pdf (accessed 11 February 2014); George McHugh, "A Word from the President," OSC Yearbook 1953-54 (Ottawa: Ottawa Ski Club Publication, 1954), 13. http://gvhs.ca/digital/gatineau-park/osc/1953-1954-year-book.pdf. (accessed 19 February 2014); Elmer Cassell, "Quo Vadis?" OSC Yearbook 1953-54, 49. http://gvhs.ca/digital/gatineaupark/osc/1953-1954-year-book.pdf. (accessed 19 February 2014); James S. Patrick, "The Trail Markers," OSC Yearbook 1953-54, 47. http://gvhs.ca/digital/gatineau-park/osc/1953-1954-year-book.pdf. (accessed 19 February 2014).

153 Doug Carman, “Trail Riders," The Ottawa Ski Club Yearbook 1947-48, 24.

http://gvhs.ca/digital/gatineau-park/osc/1947-1948-year-book.pdf (accessed 13 February 2014)
} 
space of two years and it becomes impassable." ${ }^{154}$ It only took a couple of seasons of missed clearing duty in the fall for trails to become less enjoyable in winter.

Once they were up and running, Trail Rider operations proceeded on an annual schedule of brushing in fall, as they tried to reclaim several trails that had not been brushed in years and maintain the trails' surfaces in winter. Trail Riders stayed in the bunks of the OSC Lockeberg Lodge at the foot of the Slalom Hill, named in honour of Club founder and honorary president Sigurd Lockeberg. ${ }^{155}$ From the lodge, members of the group entered the trail network starting from the west end of the valley, where the Merry-Go-Round loop and Western Trail branched into less traveled sections of the Gatineau Hills. The Night Riders were also quartered in the valley at Camp Fortune and Arnold Midgley recalled that "for a time there was some friendly rivalry between the groups, but it was all in good fun." ${ }^{156}$ Winter trail work techniques were not drastically different between the two maintenance groups. The Trail Riders crosschecked the outruns of hills and turns, set tracks with their skis following new snow, and performed a sweep of popular trails on Sunday evenings to ensure no injured person spent the night in the cold. ${ }^{157}$

As the OSC increasingly consolidated its spending at Camp Fortune, crosscountry skiers became responsible for building and maintaining their own infrastructure with volunteer labour and a limited budget. In 1947, D.L. Surveyor, who had skied the trails of the Gatineau Hills since the 1920s, penned a column in the Yearbook recounting

\footnotetext{
154 Charles Mortureux, "The Saga of the Ottawa Ski Club," The Ottawa Ski Club Handbook, 8. http://gvhs.ca/digital/gatineau-park/osc/1942-OSC-Handbook.pdf (accessed 11 February 2014).

155 Ironically, the Trail Riders stayed in a lodge named after a prolific ski jumper and alpine skier, whereas the Night Riders shared the cabin of Charles Mortureux, who openly opposed hill skiing and rope tows.

156 Arnold Midgley, interview by author, September 25, 2013, Ottawa, ON, digital recording.

157 Doug Carman, "The Trail Riders," Ottawa Ski Club Yearbook 1948-49, 16.

http://gvhs.ca/digital/gatineau-park/osc/1948-1949-year-book.pdf (accessed 13 February 2014).
} 
his own anachronistic ski from the train at Kirks Ferry, to the Pink Lake Lodge. The trail skiing experience described in "Our Day" is one rooted in the skier's relationship with the landscape and its intimate features along the trails spread throughout the hills. "Going down the road to Kingsmere we are reminded of the tricky balancing on one ski coming around Grimes' cottage, the low duck to avoid the apple tree limbs and the sigh of relief when we made the gateway onto the road." In the lodges, Surveyor and his companion "do still stick to our old habit of settling the world's and the Ottawa Ski Club's affairs at considerable length before hitting the trail for the last lap." After the day of skiing, Surveryor enjoyed the "deep contentment that follows the day of exercise and exhilarating movement." 158 These men were not competitive racers; for them, Gatineau Park's trail network was primarily a space for what Bale calls recreational sport and physical activity. ${ }^{159}$

The development of hill skiers' space at Camp Fortune, on the other hand, borrowed extensively from the "achievement sport" scenario of the "trialectic." Developments in ski technologies extended beyond the material appendages of skis, boots, and bindings, to the hills themselves. An emerging competitive alpine ski culture required the manipulation of the landscape at Camp Fortune to suit the evolving spatial needs of competitive hill skiers. In the early days of skiing, the natural landscape of Camp Fortune allowed skiers to push their personal limits and the limits of their equipment, which worked equally well on trails and hills; in this period, ski equipment of the two cultures had not yet split. As alpine ski racing developed an achievement space at Camp Fortune, wherein competition produced a hierarchical culture structured according

158 D.L. Surveyor, "Our Day,” Ottawa Ski Club Yearbook 1946-47 (Ottawa: Ottawa Ski Club Publication, 1947), 56. http://gvhs.ca/digital/gatineau-park/osc/1946-1947-year-book.pdf (accessed 11 February 2014).

159 Bale, Sports Geography, 9. 
to race results and the development of proper technique, modern equipment designed specifically for the needs of hill skiing became necessary. ${ }^{160}$ Furthermore, as skiers became more proficient in modern ski techniques and acquired contemporary equipment from Europe, they required a sportscape suitable to their modern practices, and a growing race culture. ${ }^{161}$

David Midgley recalled that for alpine skiers at Camp Fortune, "Once you learned to ski, there wasn't much challenge to the hills. Once you were self-sufficient, you raced. Everybody raced."162 The topographic limitations at Camp Fortune created a space where skiers quickly overcame the challenge of the hills themselves, and competed with one another on the slopes produced and maintained by the Night Riders and the OSC. The Yearbook displayed local race results and the international exploits of local skiers, showcasing the competitive nature of hill skiing culture at Camp Fortune. The competition column explained the motivation behind racing for the competitors: "The best of them are trying their prowess against that of their fellow-skiers, the others are learning the difficult art of ski-racing and fine skiing in the best way - by entering a competition." ${ }^{\prime 163}$ Because the hills were small, and races were short, competitors trained extensively to master proper technique in order to maximize a competitive advantage over their fellow skiers.

160 Eichberg, Body Cultures, 124.

161 Bale, Sports Geography, 13

${ }^{162}$ David Midgley, interview by author, November 12, 2013, Gatineau, QC, digital recording.

163 The OSC annually published a column in its Yearbook, that included a description of the year's racing and results from the Club Championship competitions. Bruce Heggtveit, "Competitions," Ottawa Ski Club Yearbook 1949-50 (Ottawa: Ottawa Ski Club Publication, 1950), 47. http://gvhs.ca/digital/gatineaupark/osc/1949-1950-year-book.pdf (accessed 19 February 2014); Rev. Father J.B. Zachary, "Competition Results," Ottawa Ski Club Yearbook 1948-49 (Ottawa: Ottawa Ski Club Publication, 1949), 48. http://gvhs.ca/digital/gatineau-park/osc/1948-1949-year-book.pdf (accessed 13 February 2014). 
In the winter of 1947, the OSC operated two rope tows at Camp Fortune servicing two different hillsides. The newly constructed tow on the south facing Mort's Hill was especially popular on sunny days, when skiers soaked up the beauty of the Gatineau Hills in the sheltered valley. The original rope tow brought skiers to the top of the Joe Morin Slalom Hill, a north-facing slope that was much wider and steeper than Mort's and was the venue for slalom races held by the club. ${ }^{164}$ Hill skiing attracted droves of boys like the Midgleys who spent their Sundays practicing turns and trying to reach the highest speed possible, and aspiring to reach the excellence demonstrated by local racers. The following year, two additional rope tows were operational in the valley, bringing the total to four in 1948. The FDC and OSC also expanded the parking lot at the bottom of Dunlop Road, known as the Garden of Eat-In, to accommodate up to 400 vehicles. ${ }^{165}$ A jitney service on the climb from the parking lot to Camp Fortune made it possible for the first time for skiers to reach the rope tows without ever having to climb under their own power. The jitney was privately operated on Dunlop Road, which was FDC land, and cost around ten cents. It was common practice for skiers to pay the fee for the ride up and ski down at the end of the day. ${ }^{166}$

David Midgley recalled training for slalom on the Morning After Hill at Camp Fortune alongside his fellow Night Riders, friends, and skiers. ${ }^{167}$ Although the elevation of the hills in the valley was later deemed insufficient to support national level competition, the topography allowed a downhill ski culture based on competition to

\footnotetext{
164 Arnold Midgley, interview by author, September 25, 2013, Ottawa, ON, digital recording. Arnold spoke with great fondness of sunny winter days spent in the sheltered valley at Camp Fortune, saying, "It really is quite spectacular."

165 Herbert Marshall, “A Message from the President,” Ottawa Ski Yearbook 1948-49, 13. http://gvhs.ca/digital/gatineau-park/osc/1948-1949-year-book.pdf (accessed 13 February 2014).

${ }^{166}$ David Midgley, interview by author, November 12, 2013, Gatineau, QC, digital recording.

167 David Midgley, interview by author, November 12, 2013, Gatineau, QC, digital recording.
} 
emerge. "Once you got to the point where you were self-sufficient, everybody went in for fun on the weekend race. There was one every weekend." ${ }^{168}$ Started in 1947, the Ottawa Ski Club Skimeister "interscholastic four-event ski championship" pitted clubs from the University of Ottawa, Glebe Collegiate Institute and St. Pats High School against each other on the hills of Camp Fortune. The competitive culture at Camp Fortune developed a strong racing program that competed in local, provincial, national, and international competitions. ${ }^{169}$ The spatial requirements and production of alpine ski terrain drastically changed the landscape and culture of hill skiing at Camp Fortune during the postwar period. Downhill enthusiasts allured by rope tows and the thrill of speed were quickly eclipsing trail skiers as the OSC moved further into the 1950s. Hill and trail skiers still shared the space, but the transition towards a monocultural alpine landscape at Camp Fortune began in earnest thanks to the OSC's investments there, striking a nerve with some devout trail skiers. ${ }^{170}$

I wonder if the directors of the Ottawa Ski Club ever stop to consider the older members who, by reason of their long association and patient humility have been its stable support throughout the years? I wonder if they realize that, with the advent of the new Keogan's Lodge and the Commission-maintained trails, a membership in the Ottawa Ski Club is no longer a requisite for a day's pleasure along the snowy lanes of Gatineau Ridge? I wonder if they plan to expend any of their substantial revenues on trail development and maintenance? ${ }^{171}$

This public display of unrest among trail skiers pointed out some of the reasons underlying a bourgeoning division within the club. In "An Oldtimer Protests," a devout

\footnotetext{
168 David Midgley, interview by author, 12 November, 2013, Gatineau, QC, digital recording.

169 Local skiers and OSC members John Clifford, John Fripp, Bruce Heggtveit, Anne Heggtveit, and Arnold Midgley were among several local skiers who competed internationally. Anne Heggteveit won a gold medal for Canada at the 1960 Winter Olympics in Squaw Valley, California.

170 Denning, "From Sublime Landscapes to 'White Gold," 82.

${ }^{171}$ W.S.L. "An Oldtimer Protests," Ottawa Ski Club Yearbook 1948-49 (Ottawa: Ottawa Ski Club Publication, 1949), 53. http://gvhs.ca/digital/gatineau-park/osc/1948-1949-year-book.pdf (accessed 11 February 2014).
} 
skier known only as W.S.L. recounted the events of a day of skiing in the Gatineau Hills from a time when skiers disembarked from the train line at Kirk's ferry in a lament for days before the development of hill skiing. W.S.L.'s trip from the train was even more out of place in Gatineau Park ski culture in 1949, when the majority of skiers made their way to the parking lots in the vicinity of Camp Fortune's hills and lodges by bus or car. The author described the "fascinating attraction" of trail skiing where "the crisp, bright air of a January morning; the swish of hickory through newly-fallen snow; the long, velvety glides down woodland slopes; [and] the sometimes exhausting yet satisfying climbs to gain the altitudes from which to glide once more" were the defining factors of an experience where scenery took precedence over style and technique. W.S.L. openly questioned the OSC executive's allocation of club funds and pointed out that the work of the FDC, who maintained the Ridge Road, Fortune Lane, as well as Keogan's Lodge, made a membership in the OSC unnecessary for trail skiers. ${ }^{172}$ Like Surveyor's lament years earlier, W.S.L.'s outcry demonstrated the transition from a permeable space at Camp Fortune to a bounded, consumable landscape of cleared ski runs, rope tows and lodges equipped with canteens.

There were two ways out of Camp Fortune at the end of a day of skiing. Those heading home via Kingsmere took one of the OSC rope tows out of the valley, skied east along the ridge and then down the slopes leading to the Mountain Lodge and Lemay's on Kingsmere road, where the bus picked them up. At this time traffic on Fortune Lane and the Canyon Trail changed direction, and skiers partook in a mass exodus from Camp Fortune. Any unsuspecting skiers going against the outflow risked being met head-on by

172 Unknown Author, “An Oldtimer Protests,” Ottawa Ski Club Yearbook 1948-49, 53. 
one of the Midgleys or their compatriots in the "hungry homing herd" headed to Lemay's. ${ }^{173}$

The Kingsmere-Camp Fortune section of Gatineau Park was a bustling hive of winter activity following the Second World War. The international ski industry was booming and the sport of hill skiing was rapidly becoming a specialized discipline. Ski hills became tailored specifically for the needs of modern downhill practices and competitions and growing attention to the maintenance of slopes sought to provide consistent sliding surfaces free of bumps. Hill skiers in Gatineau Park wanted to simultaneously experience nature in the rural hills and practice contemporary ski style on purpose-built terrain in the fashion popularized by European Alps skiing. ${ }^{174}$ As the crowds at Camp Fortune grew, the OSC and especially John Clifford, the man hired by the club to develop hill-skiing infrastructure, recognized the needs of hill skiers and undertook the first steps in a major landscaping and management project to transform Camp Fortune into a modern facility; they began shaping the valley and its slopes into a monocultural alpine sportscape. ${ }^{175}$ Camp Fortune's transition into a strictly alpine environment was not yet complete by 1950, though, as the valley remained a convenient starting point for trail skiers taking the popular Merry-Go-Round cross-country loop, or coming into the valley via Little Switzerland, or the Skyline Trail. OSC members who preferred alpine skiing took advantage of the growing network of rope tows and cleared

\footnotetext{
173 Doug Carman, "Speak Up, Please," Ottawa Ski Club Yearbook 1949-50, 56. http://gvhs.ca/digital/gatineau-park/osc/1949-1950-year-book.pdf (accessed 19 February 2014); Arnold Midgley, interview by author, September 25, 2013, Ottawa, ON, digital recording.

174 Denning, "From Sublime Landscapes to 'White Gold,"” 82.

175 Bale, Sports Geography, 131. Bale uses the term "monocultural sportscape" to describe spaces constructed specifically for the needs of a sport such as ski jumps, arenas, and gold courses. Denning, "From Sublime Landscapes to 'White Gold': How Skiing Transformed the Alps after 1930," 82. Denning applies Bale's concept of monocultural sportscapes to the slopes of alpine ski resorts, using the example of Austrian "piste gardiners" hired to manicure the Olympic Downhill skiing course, in 1964.
} 
slopes at Camp Fortune, as it solidified its position as mecca for the discipline in Gatineau Park.

The consolidation of resources at Camp Fortune extended to the volunteer labour force that occupied the lodges on weekend nights. When Arnold Midgley joined his brother as a member of the Night Riders in the late 1940s, the group's responsibilities were restricted to the maintenance and preparation of hill skiing surfaces at Camp Fortune only. They ceded all trail responsibilities to the newly formed Trail Riders when the workload of the rope-tow-serviced hills consumed all of their time. Between days of work, the Night Riders spent their evenings divided among three small lodges near the Fortune Lodge. Named Plante, Southam, and Mort's Cabin, the buildings offered wood stoves for heating and cooking, as well as roughly twenty bunks combined. ${ }^{176}$

In winter, the Night Riders worked hard to maintain the skiing surface at Camp Fortune by cross-checking after snowfalls, covering patches bereft of snow, and even shoveling snow out of the woods and onto the slopes. Ski traffic on the hills at Camp Fortune was so heavy that snow was pushed to the sides of the slopes on a daily basis. The Night Riders worked tirelessly to manage insufficient levels of snow on the overused slopes. ${ }^{177}$ Midgley explained: "The traffic on the ski hills was fairly concentrated, and as a result it became full of bumps or it would wear through to ground level, particularly if you had a winter when the snowfall was typically light and dry, and did not pack very well." ${ }^{178}$ The group had personal interest in good ski conditions, and the boys

176 Arnold Midgley, interview by author, September 25, 2013, Ottawa, ON, digital recording.

177 Arnold Midgley, interview by author, September 25, 2013, Ottawa, ON, digital recording.

178 David Midgley, interview by author, November 12, 2013, Gatineau, QC, digital recording. 
put the same energy towards skiing as they did working, as a well maintained surface was ideal for practicing for competition.

"One of the important objects of the Night Riders is to develop skiing and encourage participation in competitions," explained Clifford in an OSC Yearbook. The Night Riders were dedicated racers and among the strongest alpine skiers in the OSC. ${ }^{179}$ They skied together, and pushed one another to improve at weekly races held on the Cote du Nord and Slalom runs, and practiced slalom technique on the Morning After slope. The young men were mostly good friends, and many attended the Glebe Collegiate Institute together. Volunteer labour and hill skiing were the social fabric of the Night Riders. Before the first snowfall brought droves of weekend skiers into the valley, the Night Riders worked during the day widening runs, cutting brush with scythe and machete, filling holes, and removing rocks from the runs to improve the base surface. They spent evenings "carousing in the cabins." Heading "over to Beamish Hill was an adventure that took about half an hour to bushwack." There was a lodge there that hosted Saturday night dances and the Night Riders would arrive as a motley crew, often covered in mud, "to have a drink and watch the people dance." ${ }^{180}$ Arnold Midgley recognized that the boys were not the most attractive dance partners in their shabby trail building attire, but mingling was not the primary objective of the Saturday night trips. Running through the woods or along the trails, members of the Night Riders attempted to outwit one another, racing through the space in total darkness and testing their knowledge of the terrain in the process.

179 John Clifford, "The Night Riders of 1948-49," Ottawa Ski Club Yearbook 1949-50 (Ottawa: Ottawa Ski Club Publication, 1950), 35. http://gvhs.ca/digital/gatineau-park/osc/1949-1950-year-book.pdf (accessed 19 February 2014).

180 Arnold Midgley, interview by author, September 25, 2013, Ottawa, ON, digital recording. 
By 1950, at the center of the recreational trail network maintained by the Trail Riders, the OSC owned a 315-acre tract of land encompassing the cleared ski slopes at Camp Fortune, the lodges there, which the OSC owned, and the valley the hills outlined. In this area, the Night Riders, under Clifford's guidance, freely cut trees, built bridges, and landscaped slopes on Pleasant Valley, Paradise Valley, and the Cote Du Nord Hills (see Figure 7). ${ }^{181}$ The trail network maintained by the Trail Riders that branched out from Camp Fortune was mostly outside the boundary of the club's 315 acres, taking skiers through sections of private and Gatineau Park lands. ${ }^{182}$ The FDC had expropriated 2,269 hectares of land in the the Kingsmere-Camp Fortune area shown on the 1946 map (Figure 5) and in the southeastern hills where trails wove between Pink Lake, Fairy Lake, and the long abandoned Forsyth Mine. ${ }^{183}$ Camp Fortune was a privately owned recreational area within the boundaries the Gatineau Park FDC map illustrated, but the numerous tracts of private land in the area, including Camp Fortune, were not depicted to recreational trail users. ${ }^{184}$ The FDC allowed the club to maintain their existing network throughout the park and assisted the OSC in expanding their recreational facilities. Relations between the FDC and OSC were good during this period, and the recreational network they maintained was incorporated into plans for the capital region as a whole. ${ }^{185}$

\footnotetext{
181 John Clifford, “The Night Riders Season 1949-50,” Ottawa Ski Club Yearbook 1950-51, 35. http://gvhs.ca/digital/gatineau-park/osc/1950-1951-year-book.pdf (accessed 11 February 2014).

182 Michele Filion and Serge Gagnon, The Creation and Early Development of Gatineau Park, 3. Gagnon and Filion show that Gatineau Park "does not benefit from the status usually granted to large natural areas under federal or provincial jurisdiction." "Gatineau Park was not a spontaneous, complete creation, but a piecemeal creation born on the whim of circumstances, events and actions by individuals."

183 Jacques Gréber, Plan for the National Capital General Report (Ottawa: Federal District Commission, 1950), 104. https://qshare.queensu.ca/Users01/gordond/planningcanadascapital/greber1950/openspace.htm (accessed 11 February 2014).

184 David Midgley, interview by author, November 12, 2013, Gatineau, QC, digital recording. David explained how the O'Brien brothers owned the land just east of Camp Fortune on Meech Road.

185 David Midgley, interview by author, November 12, 2013, Gatineau, QC, digital recording.
} 
While the OSC was busy consolidating its recreational facilities around Camp Fortune and the Trail Riders began reinvigorating trail skiing, renewed federal interest in the development of the National Capital Region put the broader recreational role of Gatineau Park into a national conversation. The most comprehensive iteration of the National Capital's planning came in the 1950 Plan for the National Capital General Report, also known as the Gréber Plan. The plan outlined a proposed organization and improvement of the National Capital Region, including Ottawa, Hull, Aylmer, Gatineau, and Gatineau Park. Among other aspects, the plan's survey depicted the region's geographic, demographic, and recreational profile. The geographic assessment mapped the area and situated Gatineau Park as an accessible forest reserve in close proximity to Ottawa. The plan also showed that expanded federal government operations in Ottawa following the Second World War employed 32,000 local residents. ${ }^{186}$ Civil servants were the majority of the OSC's roughly 2,000 members in $1950 .{ }^{187}$ The international reputation of Jacques Gréber and federal support encouraging the beautification process of the capital led to the expansion of Gatineau Park. In 1950, the park encompassed a total of 6,475 hectares of federally owned and protected land, and park management eventually purchased roughly an additional 30,000 hectares in the following decades. ${ }^{188}$

The 1950 plan also proposed the construction of scenic automobile parkways through Gatineau Park. The report outlined that: "In [the parkways'] layouts we have taken full advantage of high elevations from which extended views of surrounding

\footnotetext{
186 Jacques Gréber, Plan for the National Capital General Report, Ottawa, 1950, 56.

https://qshare.queensu.ca/Users01/gordond/planningcanadascapital/greber1950/activities.htm (accessed 11 February 2014).

187 Michael MacConaill, interview by author, November 13, 2013, Gatineau, QC, digital recording.

188 Dennis Messier, "Save the Hills!," The Gatineau Park Chronicle 2007, National Capital Commission, 2007. http://gvhs.ca/digital/gatineau-park/chronicles/save.html (accessed February 11 2014).
} 
territories can be obtained." ${ }^{" 189}$ Automobile parkways would make the park increasingly accessible to the general public, Ottawa residents, and tourists to the national capital during the summer months. In 1953, the FDC produced the General Report for the Parkway Subcommittee for Gatineau Park, which outlined a plan for the construction of a more extensive system of scenic automobile roads than the Gréber Plan. Alisa Apostle's work explores the planning stages leading up to the construction of the parkways, and situates the FDC's actions within the wider context of automobile nature tourism. ${ }^{190}$ However, the construction of the roads, and their impact on the environment warrant further research. The parkways appeared on the 1957 OSC Trail Map, but they are not addressed by this thesis because the roads were built for cars, not skis, and were not an important part of the Gatineau Hills' sportscape before $1967 .{ }^{191}$

Land ownership within the Kingsmere-Camp Fortune area of Gatineau Park was divided between the OSC, who owned 315 acres in the valley at Camp Fortune, a handful of private lots, cottages, and farms not yet expropriated, and the FDC who owned and managed the remaining acreage. Private operators at Beamish Hill and Quipp's farm offered rope tow services to skiers facilitating their transgression between private and public lands. The only boundary on the network that existed for skiers was the growing division between users of cross-country trails and those who preferred the rope-tow hills

\footnotetext{
189 Jacques Gréber, Plan for the National Capital General Report, Ottawa, 1950, 173. https://qshare.queensu.ca/Users01/gordond/planningcanadascapital/greber1950/circulation_plan.htm (accessed 11 February 2014).

190 Apostle, "The View from the Hill: National Park Culture and Gatineau Park 1920-1960,” 103.

191 Skiers did begin using the Parkways as a way of moving through Gatineau Park, but the trails were the primary space used by cross-country skiers before 1967. Joseph Woods, interview by author, September 12, 2013, Chelsea, QC, digital recording.
} 
of Camp Fortune. ${ }^{192}$ Cottagers and homeowners on Kingsmere Lake and along Kingsmere Road living adjacent to the trail network tolerated trails across their land, to a certain extent, but "not all the bush owners applauded the efforts of the Club. Few complained so long as the trails were no wider than the average between trees on the bush, but when their width was extended in parts to twenty or thirty feet, many claims for damages were presented."193

With initial land purchases of 5,000 acres, the FDC owned the largest portion of land in the Kingsmere-Camp Fortune area. ${ }^{194}$ Their winter trail map of 1946 presented a homogeneous image of recreational space for visitors to Gatineau Park. On the ground, skiers almost inevitably traveled through both private and public lands along the OSC trail network and private landowners took advantage of the economic opportunity presented by the recreational population. At Kingsmere, Eddy Quipp allowed skiers to clear a wide trail on his land, and he did not charge a fee to ski there, only to use the rope tow service he offered, linking Kingsmere Road with the Ridge Road trail. Lemay's Restaurant and the Mountain Lodge, located next to Quipp's lift, offered refreshments and hospitality to paying customers regardless of club affiliation. Captain Gerald Wattsford owned 100 acres adjacent to Quipp, the Mountain Lodge was on his property, and a lookout over the area was adorned with his name. ${ }^{195}$

\footnotetext{
192 Bale, Sports Geography, 5. Bale refers to this division as "the changing character of the sports landscape and the symbiosis between the sports environment and those who participate in it."

193 Charles Mortureux, "The Saga of the Ottawa Ski Club," The Ottawa Ski Club Handbook, 8.

194 NCC, Gatineau Park Master Plan (Ottawa: NCC, March 1990), 29-33, This figure is not definitive, as Jean-Paul Murray has argued it was 15,000 acres. Jean-Paul Murray, "Gatineau Park's Forgotten Founder," The Ottawa Citizen (Dec 08, 2003). http://search.proquest.com/docview/240707536?accountid=9894 (accessed 13 February 2014).

195 "Wattsford Lookout," National Capital Commission trail sign at the intersection of Ridge Road and the Penguin hill, near the beginning of the Skyline trail. Sign photographed by author February 10, 2014.
} 
In winter, the relationship between skiers, private landowners, the OSC, and the FDC operated quite smoothly for decades. ${ }^{196}$ The presence of mechanical rope tows in postwar Gatineau Park catered to an emerging population of hill skiers whose modern form of recreation combined a perceived nature experience in a landscape treated by the OSC and FDC as a "natural resource to be harvested, managed, and developed."197

The postwar era saw the development and improvement of road infrastructure and winter clearing services by the FDC. This allowed skiers to be in immediate proximity of the cleared hillsides of Camp Fortune from their cars or the Gatineau Bus. The OSC greatly benefitted from the postwar expansion of the civil service in Ottawa, growing its membership to unprecedented numbers. This growth in the ski population put increased strain on ski infrastructure, and the issue of crowding further strained the hills at Camp Fortune.

In 1949, Club President Herbert Marshall pointed out the drastic changes Camp Fortune underwent during the previous summer. He referred to the cooperation between the FDC and OSC that resulted in the expansion of the Dunlop Parking lot, the undertaking of widening Dunlop Road, the widening of the Joe Morin Slalom, the official opening of the new Lockeberg Lodge, and the clearing of an entirely new run on a hill on the north side of the valley, next to Mort's. The OSC and FDC undertook these improvements to solve the recurring issue of overcrowding that plagued the lodges and hills of Camp Fortune brought on by the rising popularity of hill skiing.

The postwar period saw John Clifford take on a leading role in the development of hill skiing infrastructure at Camp Fortune. A long time OSC member, Pan American

196 Michael MacConaill, interview by author, November 13, 2013, Gatineau, QC, digital recording; David Midgley, interview by author, November 12, 2013, Gatineau, QC, digital recording.

197 Denning, "From Sublime Landscapes to 'White Gold,"” 82. 
Alpine skiing champion, and member of the Night Riders, Clifford was "a visionary" in the local ski community. ${ }^{198}$ In the late 1940s and early 1950s, however, "many skiers of the old school preferred to climb" and the acceptance of "crude if not dangerous" rope tows by the general public was not yet in full effect. ${ }^{199}$ Clifford's forward thinking approach to Camp Fortune's development of hill skiing and lifts in the late 1940s laid the foundation for an alpine ski community on the brink of drastic and rapid expansion. His energies, though, were still primarily directed towards competing in downhill and slalom events, and Clifford was selected for Canada's National Team in $1950 .{ }^{200}$

Part of the developments at Camp Fortune of 1949 was a new south-facing run named in honour of Governor General Viscount Alexander. Catering to intermediate skiers, the run offered a long sliding surface that contoured the hill to alleviate the slope and extend the length of the skiable surface. The Viscount Alexander Hill and Lockeberg Lodge spread out the crowds in the valley both indoors and out, but the arrival of new skiers continued to outpace the maintenance capacities of Clifford and the Night Riders who still laboriously cross-checked most of the runs. ${ }^{201}$ Hill skiing in the 1950 s required runs of at least thirty feet in width, extensive tree removal, and landscaping with heavy machinery and dynamite. Cooperation between Club and Commission allowed advancements in hill skiing at Camp Fortune to be made, but neither organization profited financially from their work. President Marshall wrote that the developments at Camp Fortune "would not have been possible had it not been for assistance given by the

\footnotetext{
198 Dave Midgley, interview by author, November 15, 2013, Gatineau, QC, digital recording.

199 Kaufmann and Stevens, White Gold, 51.

200 Andy Tommy, "Competitions 1949-1950," Ottawa Ski Club Yearbook 1950-51 (Ottawa: Ottawa Ski Club Publication, 1951), 31. http://gvhs.ca/digital/gatineau-park/osc/1950-1951-year-book.pdf (accessed 11 February 2014).

201 Dave Midgley, interview by author, November 12, 2013, Gatineau, QC, digital recording.
} 
Federal District Commission. This help is a recognition of the fact that the FDC and the OSC have a common objective in the promotion of wholesome recreational facilities in Gatineau Park." ${ }^{202}$ The financial interests of developers did not dictate the changes at Camp Fortune as they did in the postwar Rocky Mountain and Alps resorts. ${ }^{203}$

OSC Chairman of Hills and Trails, Doug Carman, directly addressed members on the changing needs of the club, asking them to "Speak Up, Please" so that club executives' could best accommodate their needs as they cooperated with the FDC in planning for the upcoming season of $1950 .{ }^{204}$ In response to growing demand for hills after the improvements of 1949, the club once again put unprecedented amounts of work and money towards developing ski infrastructure; using heavy machinery and pneumatic compressors to displace rock to expand parking lots, widen runs, and work on the new Lockeberg jump. ${ }^{205}$ The improvements to infrastructure and growing automobile culture of the 1950s made parking close to the hill increasingly important for visitors and further consolidated Camp Fortune's centrality in the recreational space.

Working alongside the OSC, the FDC invested significant resources in widening and improving Dunlop Road to the Camp Fortune valley in the summer of 1950. For the first time, skiers and pedestrians alike could drive their cars or take the Gatineau Bus

\footnotetext{
202 Herbert Marshall, "Remarks by the President," OSC Yearbook 1948-49, 9. http://gvhs.ca/digital/gatineau-park/osc/1948-1949-year-book.pdf (accessed 13 February 2014).

203 For works on profitable ski resorts see Childers, Colorado Powder Keg; Coleman, Ski Style; Coleman, "The Unbearable Whiteness of Skiing"; Denning, "From Sublime Landscapes to "White Gold,"; Duke Richey, "The Aspenization of Telluride: Coming of Age and Mythologizing Change in Ski Country, 19451985." Pacific Historical Review Vol. 79, No. 2 (May 2010) (pp. 231-264); Rothman, Devil's Bargains; Rothman, "'Powder Aplenty for Native and Guest Alike."'

204 Doug Carman, “Speak Up, Please," Ottawa Ski Club Yearbook 1949-50, 56. http://gvhs.ca/digital/gatineau-park/osc/1949-1950-year-book.pdf (accessed 19 February 2014). David Midgley worked for John Clifford at Camp Fortune during this period, and was also the captain of the Night Riders. He explained that relations between the FDC, OSC, and John Clifford Lifts were amicable for many years. David Midgley, interview by author, November 12, 2013, Gatineau, QC, digital recording. 205 Herbert Marshall, “A Message From the President,” Ottawa Ski Club Yearbook 1959-51, 12.
} 
directly to Lockeberg Lodge, at the foot of the Joe Morin Slalom run in the valley of Camp Fortune. Skiers disembarked and walked to the nearest rope tow, where they began a day of hill skiing without ever having to push uphill. ${ }^{206}$ Direct winter access by car and bus was a significant step for hill skiing at Camp Fortune, and skiing in Gatineau Park in general. A new skier could master proper techniques on the PeeWee hill, which offered a gentle grade for beginners, and then gradually attempt more challenging runs; there was no need to explore the trails, as Camp Fortune offered the full gamut of modern ski facilities in one location. ${ }^{207}$ Trail skiing and hill skiing were no longer bound by the geography of the trail network, as automobile access to Camp Fortune valley effectively divided skiing into two distinct sports with different spatial requirements. After 1950, the only space most trail and hill skiers shared was the parking lot at Camp Fortune.

The development of a modern ski hill at Camp Fortune in the early 1950s, was not an isolated occurrence. Ski hills in the Canadian Rockies were growing increasingly mechanized, as operators at Norquay, Sunshine Village, Lake Louise, Kimberley, and Nelson bolstered their infrastructure with Tbars, rope tows, and even chairlifts. ${ }^{208}$ These ski hills were primarily resorts, built to benefit from the emerging ski tourism industry in the United States and Europe, but Camp Fortune attempted to emulate the mountain resorts in their ability to move skiers to the top of the hill efficiently.

Although increasingly divided spatially, hill and trail skiers' equipment, at this point, was still very similar, if not identical. Midgley recalled that skis were "[m]uch more multi-purpose back then": in the 1950s skis had wooden bases, metal edges were

\footnotetext{
206 Herbert Marshall, “A Message from the President," 12.

${ }^{207}$ Arnold Midgley, interview by author, September 25, 2013, Ottawa, ON, digital recording.

208 Scott, Powder Pioneers, 102-118.
} 
still rare, and bindings connecting the foot to the ski could be adjusted to fix the heel of the boot to the ski for descending or allowed to move when climbing, doing neither task with great efficiency. ${ }^{209}$ The bounded geography of Camp Fortune separated hills from the trails, and allowed alpine skiers to adopt equipment specifically designed for the physical demands of hill skiing. The competitive culture of hill skiing and the efficient society it produced at Camp Fortune embraced technological advancements and the competitive advantage of specialized equipment trickled down into the ranks of recreational skiers. ${ }^{210}$

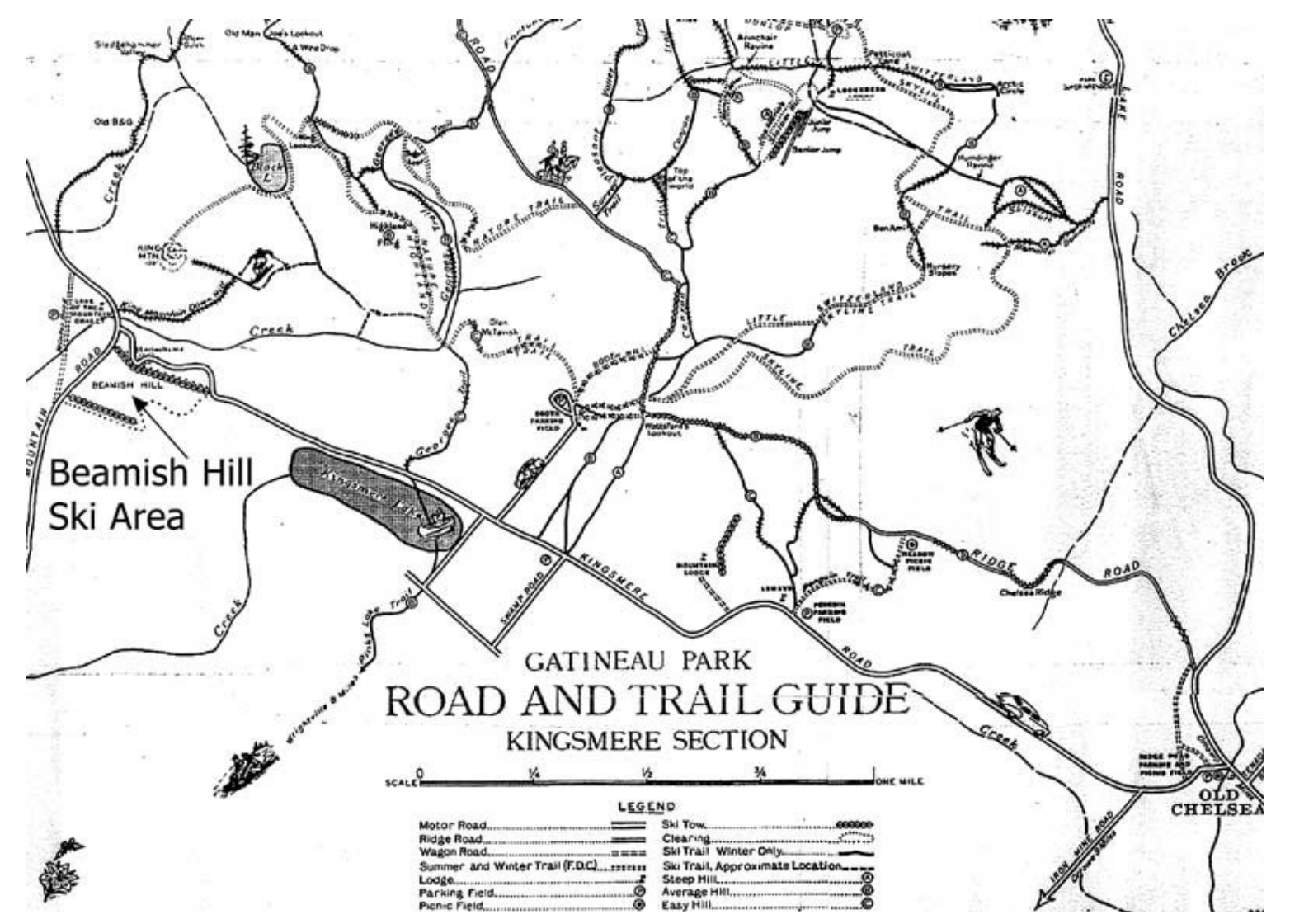

Figure 7: 1951 Ottawa Ski Club Trail Map, 1951.

209 Michael MacConaill, interview by author, November 13, 2013, Gatineau, QC, digital recording. 210 Eichberg, Body Cultures, 124. 
Maps helped trail skiers know and consume Gatineau Park space by facilitating trail skiers' movement through the experiential and recreational landscape, and allowed hill skiers to easily identify the two hill skiing locations on the map. The FDC and OSC issued the maps, but Trail Riders Doug Carman and Verne Tant "worked out most of the detail" in the outlines of recreational trails. ${ }^{211}$ The maps served a more important role for trail skiers, who were free to choose how long or challenging a day of skiing would be according to the route they planned on the map. Lodges or lookouts acted as objectives to be met. However, trails were poorly indicated and trail names were rarely visible on the ground, so colloquial knowledge was the most accurate guide through the network. ${ }^{212}$

The 1951 map showed that hill skiers' major access points to the KingsmereCamp Fortune area were at Camp Fortune and Beamish Hill, and trail skiers' main access points to Gatineau Park were via the Penguin Picnic area, Booth Hill, the Garden of EatIn at the bottom of Dunlop Road, Old Chelsea, and Lemay's. The map facilitated skiers' choice of where to access either hills or trails, a choice that became increasingly individualized with the popularization of cars in the 1950s. Cars were a popular means of exploring nature, and Gatineau Park would undergo significant transformation to satisfy the needs of a Canadian automobile tourism culture. The Parks Branch promoted roads as "symbols of a modern nation working with the individual to achieve personal betterment." 213

211 James Patrick, "Editorial," Ottawa Ski Club Yearbook 1951-52 (Ottawa: Ottawa Ski Club Publication, 1952), 9. http://gvhs.ca/digital/gatineau-park/osc/1951-1952-year-book.pdf (accessed 11 February 2013). 212 L.B. Skinner, "Place Names," Ottawa Ski Club Yearbook 1951-52, 47. http://gvhs.ca/digital/gatineaupark/osc/1951-1952-year-book.pdf (accessed 11 February 2013).

213 Alan MacEachern, "M.B. Williams and the Early Years," in A Century of Parks Canada, 1911-2011, ed. Claire Elizabeth Campbell (Calgary: University of Calgary Press, 2011), 41. 
In the 1950s, learning how to ski involved developing the fundamental skills of edge control, turns, and reducing speed on the slopes of Camp Fortune or Beamish Hill. ${ }^{214}$ In only a few years, the way people in the National Capital Region learned how to ski had changed. Beginners and advanced racers alike shared Camp Fortune space, making a large discrepancy in skill level between the thousands of skiers who migrated to the hills on winter weekends. The creation of the five-day workweek for civil servants in 1952 put even more skiers on the snow, more often, straining hill surfaces, which deteriorated rapidly and kept the Night Riders busily attempting to salvage conditions. ${ }^{215}$

The second ski area in Gatineau Park, although not operated by the OSC, is worth mention here. Beamish Hill, located in the southwest corner of the 1951 map, was privately owned and operated by the RA Ski Club. The Hull Bus Line brought skiers directly to the hill, and car owners often lined the Mountain Road with their vehicles when the small parking lot filled up. ${ }^{216}$ "Beamish's" offered the most comparable hill skiing terrain and facilities to the OSC's infrastructure at Camp Fortune. Its location on the south edge of the Eardley Escarpment allowed skiers to slide in the sunshine during the day and relax in the chalet located there to socialize at night; it is here that the Night Riders ventured on those fall evenings. ${ }^{217}$ But Beamish offered more than just an alternative set of runs from Camp Fortune; skiers could even ski there at night.

The hill was the first place in Gatineau Park to offer illuminated runs for night skiing. A series of 200-watt lightbulbs strung up alongside the Lauriault Hill, which was the lower section of Kingsmere Road in summer, provided enough light for skiers to slide

\footnotetext{
214 Michael MacConaill, interview by author, November 13, 2013, Gatineau, QC, digital recording.

215 Arnold Midgley interview by author, September 25, 2013, Gatineau, QC, digital recording.

216 Michael MacConaill, interview by author, November 13, 2013, Gatineau, QC, digital recording.

217 Arnold Midgley interview by author, September 25, 2013, Gatineau, QC, digital recording.
} 
long into the evening during the short daylight hours of winter. The lights allowed for Wednesday night races to be held, and Beamish hosted weekend races, as well. ${ }^{218}$ Skiers chose to ski the slopes at Beamish for a number of reasons. It was a less intimidating hill than Camp Fortune, with a gentler pitch, making it well suited to recreational skiers, and weeknight skiing and regular races attracted competitive types, too. Although busy, congestion on the hill was less intense, and the family owned and operated ski area allowed skiers to exercise some choice in how they consumed the Gatineau Hills. ${ }^{219}$

Crowding caused more serious problems than poor skiing conditions in Gatineau Park; injuries on the hills and trails, some quite serious, required a medical support system to treat injured skiers and get them off the trails and to the hospital. The Saint John Ambulance provided first aid assistance to the Kingsmere-Camp Fortune section of Gatineau Park, which they referred to as the "Gatineau Zone." A volunteer corps of trained paramedics was stationed in a cabin in Old Chelsea, from where they responded to emergencies on the trail network. The St John Ambulance published an annual report in the OSC yearbook, where ambulance officers assumed a very cautionary tone and offered strong recommendations against dangerous ski practices, outlining acceptable behaviour in the space. They discouraged skiing alone, dissuaded beginners from attempting runs outside their skillset, and publicly warned expert skiers against bringing inexperienced skiers down difficult slopes. ${ }^{220}$ The 1951 map classified hills by degree of difficulty to help prevent inexperienced skiers from attempting slopes beyond their capabilities. The first fatal ski accident in Gatineau Park occurred in February of 1951,

\footnotetext{
218 Allan Richens, "Beamish Hill and Beyond," Up The Gatineau!, Vol 34 (2008). http://www.gvhs.ca/publications/utga-beamish-hill.html (accessed 11 February 2014).

219 Arnold Midgley interview by author, September 25, 2013, Gatineau, QC, digital recording.

220 Howard Bergin, “'We' and the skiers," Ottawa Ski Club Yearbook 1948-49, 37. http://gvhs.ca/digital/gatineau-park/osc/1948-1949-year-book.pdf (accessed 13 February 2014).
} 
when Paul Allen from Ottawa struck a tree during a downhill race on the infamously narrow King Mountain downhill run, in poor skiing conditions brought on by the weather. $^{221}$

Downhill skiing at Camp Fortune appealed to teenagers and young men for the competitive and thrilling aspects, but the improvements in accessibility that consolidated both investment and skiable terrain in the Camp Fortune valley also encouraged participation by the general public. Camp Fortune was a space shared by competitive racers in need of modern facilities, recreational skiers seeking physical improvement, and people simply looking for a new sports experience. The different body cultures consumed the hills for different reasons and the space developed to accommodate beginner, recreational, and competitive skiers' spatial needs in one area, but Camp Fortune needed to expand to allow for further growth. ${ }^{222}$

The diminishing interest in trail skiing stirred feelings of resentment among some trail skiers as the club increasingly catered to the development of hills and tows at Camp Fortune. Two industrious trail skiers, however, took matters into their own hands. Having recognized the club's new downhill orientation, trail skiers and tireless volunteers Harman Cahill and Ferdie Chapman undertook the project of properly indicating the cross-country trails to promote the network. Dubbed "The Trail Markers," Cahill and Chapman painted hundreds of metal discs red and hammered them to trees lining the side of trails; they also installed signs bearing trails' names as part of an effort to reinvigorate trail skiing. "Newcomers will be constantly reminded which trail they are following and correctly informed at the junctions. In addition, this perpetuates our traditional trail

\footnotetext{
221 James Patrick, “The Season of 1950-51,” Ottawa Ski Club Yearbook 1951-52, 17. http://gvhs.ca/digital/gatineau-park/osc/1950-1951-year-book.pdf (accessed 11 February 2014). 222 John Bale, Sports Geography, 8.
} 
names and gives a picturesque touch to our ski terrain." 223 The two Trail Markers were a perennial fixture in the woods of the Kingsmere-Camp Fortune area, and along the trails that extended west towards Keogan, Shilly Shally, Western, and Mckinstry Lodges. The trails were in rough shape. Large trees blocked some sections of trail, forcing skiers to go around the deadfall. This changed the original line of the trail, compromised the experience for skiers, especially if the tree obstructed a hill or turn, and effectively discouraged some skiers from exploring the trails. Cahill and Chapman attempted to solve the uncertain trail conditions by clearing deadfall and removing branches.

\footnotetext{
223 James Patrick, “The Trail Markers," Ottawa Ski Club Yearbook 1955-56 (Ottawa: Ottawa Ski Club Publication, 1956), 47. http://gvhs.ca/digital/gatineau-park/osc/1955-1956-year-book.pdf (accessed 11 February 2014).
} 


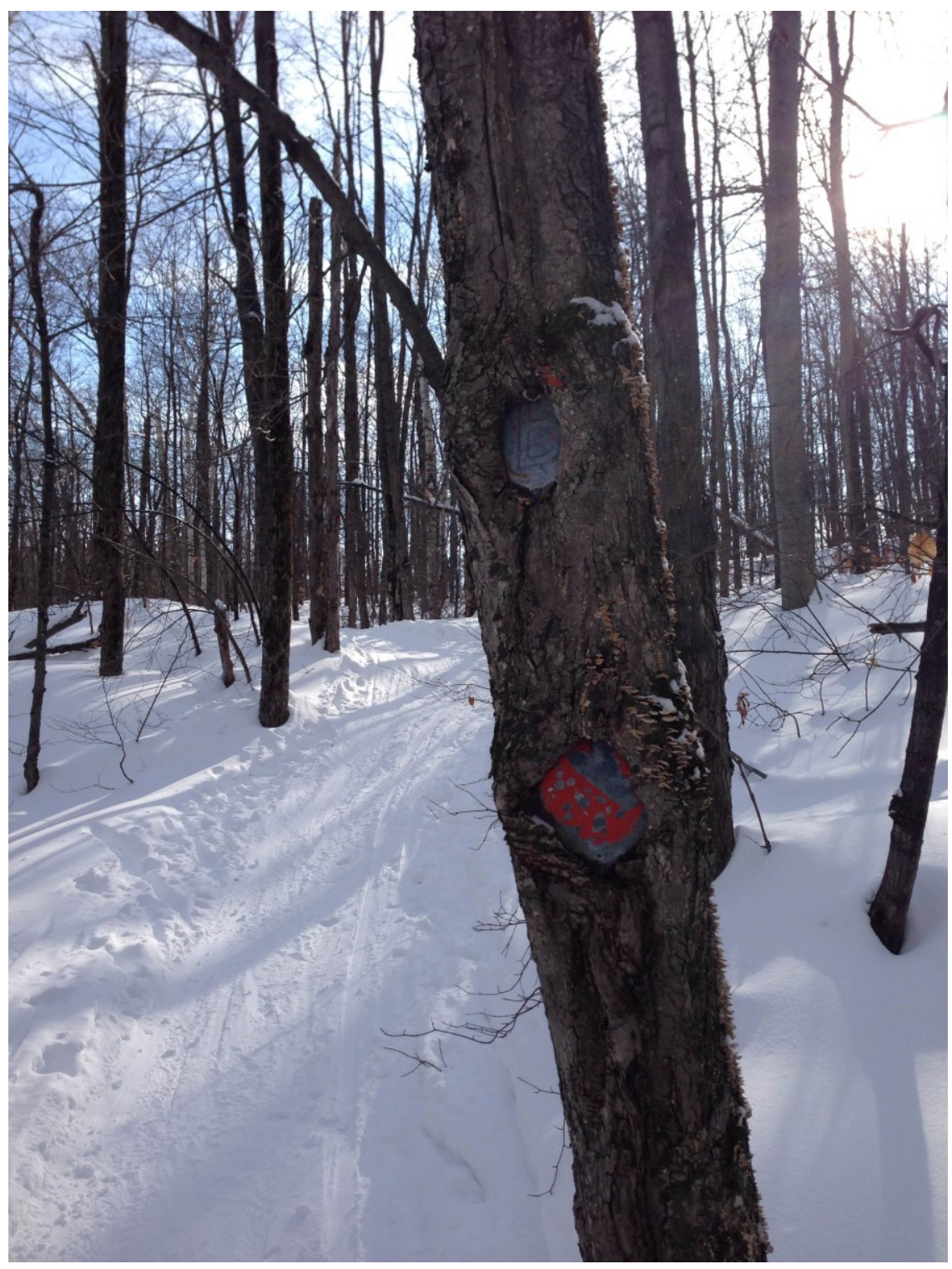

Figure 8: Trail markers on Frank's Trail (trail 17). The tree has grown around the metal discs, but some of the red paint remains. Photo by author, 10 February 2014.

On the cleared slopes of Camp Fortune, ski infrastructure developed to reflect modern trends of resort skiing local skiers longed to imitate and recreate. OSC yearbooks advertised the material aspects of Alpine ski culture; skis, ski togs, and boots from Europe were available at local retailers, as well as columns recounting members' trips to 
the mountains. ${ }^{224}$ The OSC and John Clifford Lifts undertook major landscaping projects at Camp Fortune to deliver terrain suitable for all skill levels in a modernizing hill skiing culture galvanized by the strong local racing community. ${ }^{225}$ Arnold Midgley recalled, "At the peak I would guess there was maybe ten or a dozen rope tows scattered around the valley on different slopes and different sides. It was great fun." 226

The fun offered by the hill skiing terrain at Camp Fortune required intense landscaping, heavy machinery, and professional work; the volunteer labour of the Night Riders could not meet the demands of developing a modern ski hill. Even the task of cross-checking the multiplied hills was too much, and Clifford paid men to tramp the runs down with snowshoes and shovel snow out of the woods by hand, making the Riders' volunteer labour unnecessary. In 1955, David Midgley, Director of the Night Riders, made the decision to put an end to the organization. "There wasn't anything to do, it was just a party place. It was time to stop it. You had to have a project, you know, something to do." 227 Informal labour by a volunteer group was incompatible with the modern sportscape of Camp Fortune.

Following their dissolution, the Ottawa Ski Club Yearbook honoured the legacy of the Night Riders with a history of the group and summed up the their role in the ski community. "During the three decades of its existence the Night Riders organization developed not only ski terrain, it developed its members, physically and mentally.[...] They learned the discipline of living together in cabins and cooking their own meals, of

224 Ottawa Ski Club Yearbooks from 1946-1957 all included advertisements from various shops and department stores in Ottawa that offered ski equipment: Hegtveitt's, Eaton's, Holt Renfrew, Ritchie's, Bryson Graham, Devlin's, Dover's Hardware and Spoting Goods, Plaunt Hardware, and A.J. Freiman Limited.

225 Denning, "From Sublime Landscapes to 'White Gold,"” 82.

226 Arnold Midgley, interview by author, September 25, 2013, Ottawa, ON, digital recording.

227 David Midgley, interview by author, November 12, 2013, Ottawa, ON, digital recording. 
pitting themselves against Nature and the element. They learned hard manual labour and team work; they developed self-reliance, courage and loyalty."228

Following the dissolution of their informal maintenance force, Camp Fortune further asserted itself as a modern ski hill for the season of 1956, by offering its first Tbar tow to bring skiers to the top of two newly cleared hills. T-bars were much more userfriendly than rope tows. Because skiers were pulled up the hill from below the waist, the T-bar did not require as much upper body strength, nor was there a risk of losing a glove to the rope. Uphill mobility was equally important to the development of hill skiing at Camp Fortune as the clearing and maintenance of downhill runs. During the postwar period, the popularity of hill skiing transformed the landscape in the Camp Fortune valley into a monocultural sportscape. A strong racing community incorporated advancements in ski technology into the ski community at large; Ottawa's population growth increased demand for recreational use of the space by families; and the professionalization of the workforce at Camp Fortune laid a framework for a period of further growth and development.

The developments of hill skiing changed the way skiers came to know the park. Skiers in 1947 “all started off as trail skiers" because, like the Midgley's, they skied across trails to reach the hills of Camp Fortune. By 1956, trails were no longer the first point of contact through which skiers came to know the area, the development of hill skiing infrastructure at Camp Fortune reconfigured Gatineau Park space. Automobiles

\footnotetext{
${ }^{228}$ Jim Patrick, "Saga of the Night Riders," Ottawa Ski Club Year Book, 1955-56 (Ottawa: Ottawa Ski Club Publication, 1956), 54. http://gvhs.ca/digital/gatineau-park/osc/1955-1956-year-book.pdf (accessed 11 February 2014).
} 
delivered skiers directly to the bottom of cleared and manicured hills, where T-bars and rope tows brought them to the top of the hill without any effort of their own. ${ }^{229}$

Skiers once moved freely through the intertwined sports spaces of trail and hill skiing in Gatineau Park, exploring trails and hills as they ventured across the homogenous recreational space depicted by the 1946 map (figure 5). By 1951, the OSC map (figure 6) included rope tows, parking lots, and depicted Camp Fortune and Beamish Hill as part of the trail network, only identifiable by the rope tows, the maps allowed skiers to know which spaces were conducive to hill skiing. The 1957 OSC map (figure 9), superimposed developments in infrastructure on top of the previous map, drawing attention to the newly constructed parking lot at Camp Fortune that made hill skiing directly accessible by car or bus. It also outlined the broad, cleared slopes there, and affirmed Camp Fortune's central position in a Gatineau Park ski space that now offered two distinct forms of skiing, each with their own space.

${ }^{229}$ Michael MacConaill, interview by author, November 13, 2013, Gatineau, QC, digital recording. 
Chapter Three: Distinct Skiing Communities and the Sportscaping of Gatineau Park, 1957-1967

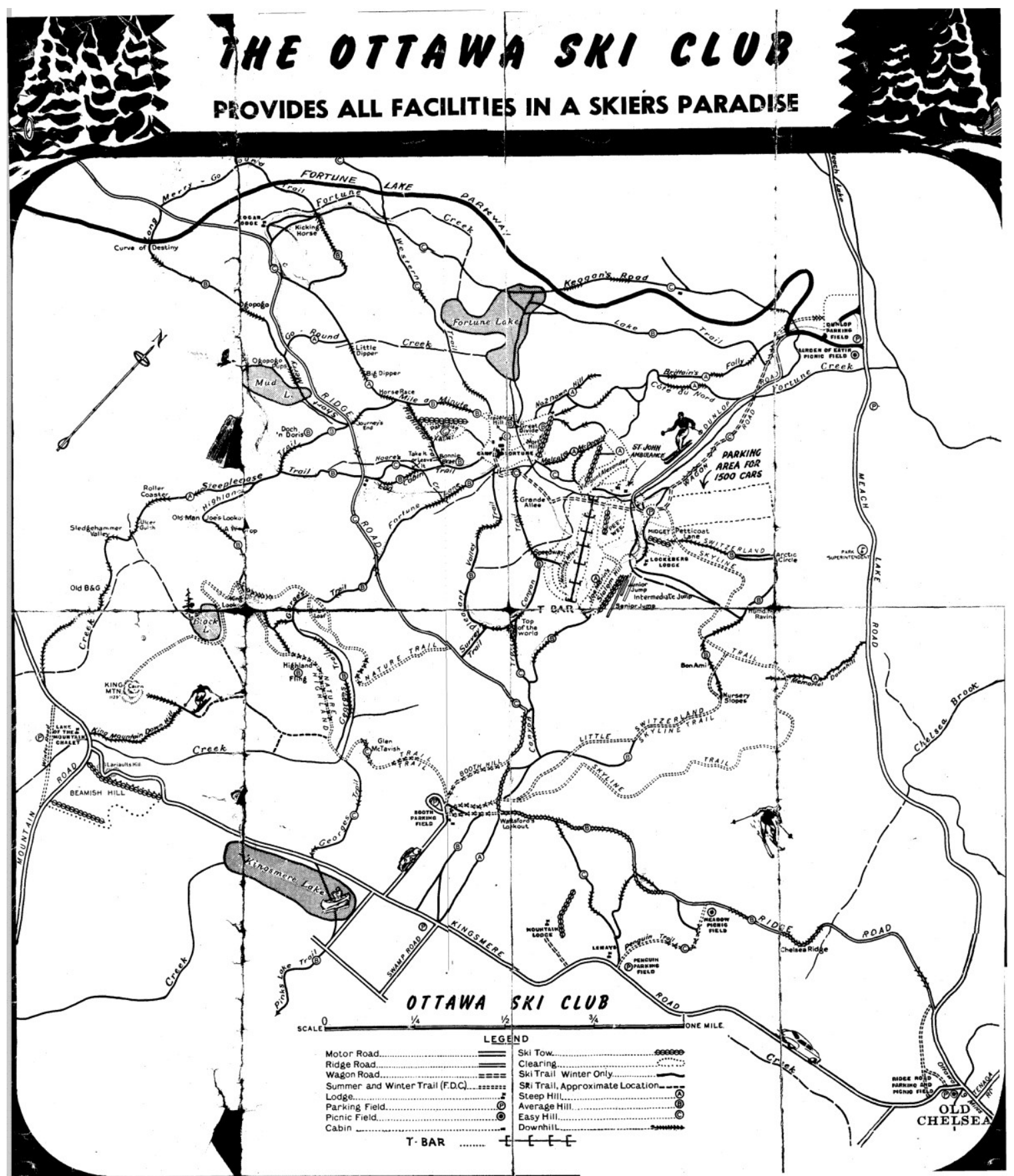

Figure 9: Ottawa Ski Club Trail Map, 1957.This map is in Michael MacConaill's possession. MacConaill explained that map was distributed by the Ottawa Ski Club along with membership badges. The OSC used the same basic map from 1951, but with improvements added each year, including parking lots, rope tows, Tbars, lodges, and outlines of cleared ski hills. 
I can think of no one better qualified to tell you about our trails than Harmon Cahill. Most of you probably do not know him because Harmon is a modest man who would rather work quietly, improving the trails he loves, than in the public eye. ${ }^{230}$ James Patrick, OSC Yearbook, 1960

On January 1, 1957, Harmon Cahill took the Gatineau Bus from Ottawa to Lemay's Restaurant on Kingsmere Road. He got off the bus, climbed up the hill named Excelsior that lead to the height of land where Ridge Road led to the Canyon Trail, which he took down to Camp Fortune. Cahill spent the rest of the day skiing around the Gatineau Hills, covering roughly thirty kilometers of hilly trail without once using the mechanical assistance of a rope tow. After sliding down the Canyon into Camp Fortune, quickening his pulse on the first of many descents that day, he climbed up from the west end of the valley on the Mile a Minute trail, onto the Long Merry-Go-Round loop. The first section of Merry-Go-Round brought Cahill up and down a series of hills scaling and sliding over ridges into small valleys, each descent had a name hinting to its severity. The first hill was Horse Race, then the Big Dipper, the Little Dipper, and finally Kicking Horse, the longest of the four and the only one that ended in open terrain, on the frozen surface of Fortune Lake, just north of Keogan's Lodge. ${ }^{231}$

The Long Merry-Go-Round was a popular trip. One of the oldest trails built by the OSC, it started near Fortune Lodge and headed west before looping back towards the Ridge Road and finally coming full-circle to Fortune Lodge. ${ }^{232}$ Although he skied the loop frequently, his trip was not over after a mere ten kilometers on the Merry-GoRound. He pressed on to the southeast, climbing up the Highland Trail from Ridge Road,

\footnotetext{
230 Harmon Cahill, “Gatineau Park Ski Trails,” Ottawa Ski Club Yearbook 1959-60, (Ottawa: Ottawa Ski Club Publication, 1960), 30; introduction by James S. Patrick. http:/gvhs.ca/digital/gatineaupark/osc/1959-1960-year-book.pdf (accessed 11 February 2014).

231 Harmon Cahill. Unpublished Diary. 1956-1968. In the possession of Mark Dagenais.

232 Michael MacConaill, interview by author, November 16, 2013, Gatineau, QC, digital recording.
} 
to Old Man Joe's Lookout, before enjoying the slide down the "Highland Fling" to George's Trail, where he crossed the frozen surface of Kingsmere Lake. Cahill skied further still, across the open fields of the Mackenzie King Estate, onto the Pink Lake Trail (formerly the Mica Mine Trail). As he neared Wrightville, he passed the abandoned pits of Pink Lake Mine and the open cuts left by the Forsythe Mine in the southeastern foothills of the park, visual reminders that the trail owed its existence to the hills' industrial past. His ski concluded in Hull, which he still referred to as Wrightville, where public transportation took him back to Ottawa. ${ }^{233}$

Like the Midgleys a decade prior, Cahill climbed up the hill where Eddy Quipp's rope tow still offered mechanical assistance. Choosing to climb up to the ridge under his own power, however, had a different meaning for Cahill than it did for the young brothers ten years before. For David and Arnold Midgley, the hills of Gatineau Park were a space for practicing and improving their alpine ski style, to compete, and to push the limits of their equipment and their bodies in a high velocity activity. The hill they climbed from the bus stop at Lemay's had a name, but the Midgleys never referred to it as Excelsior, only recalling the climb as a necessary evil in their quest for the descents at Camp Fortune. They repeatedly slid down the groomed slopes of Camp Fortune and climbed only when necessary. Skiing for the Midgleys was an achievement sport. Competition, technology, and a developing sportscape determined their interaction with Gatineau Park space and directed them to Camp Fortune. ${ }^{234}$ Trail skiers like Cahill referred to the climb as Excelsior, a name that had existed in Ottawa Ski Club vernacular for decades, inspired undoubtedly by its poetic meaning "ever higher," as the trail was the

\footnotetext{
233 Harmon Cahill. Unpublished Diary. 1956-1968. In the possession of Mark Dagenais.

234 Bale, Sports Geography, 131.
} 
final ascension to the height of Ridge Road. Like the exciting hills and treacherous turns on the Merry-Go-Round, the intimate physical relationship trail skiers had with the Gatineau Hills gave the names their meaning.

Cahill was a staunch trail skier and long-time member of the OSC. His relationship with the hills was based on long trips where he covered great horizontal distances. He encountered many hills on his trips, but rarely skied the same slope twice in one outing. The experience of sliding downhill was part of a larger sport experience of adventure, physical stamina, and recreation. Although trails were built with an intended direction, not all hills were necessarily the loci of exhilarating descents; many were climbs. The narrow, twisting hills on the trail network offered a different experience compared to the wide and groomed slopes of Camp Fortune, downhill slides on the trails offered a feeling of satisfaction; they were the reward for a straining climb. Climbs could be brief sections of steep trail that required a hastened pace of the feet and hands to propel a skier up and over the crest without experiencing the dreaded "backslip," 235 while other climbs were long and gradual. Trail skiers settled into a physical rhythm and interacted with the sweeping trail network of Gatineau Park, a series of climbs and slides.

Cahill's diaries tell the story of a dedicated and judicious skier. His outings are numbered, to keep track of the "trips" made that season. Over the winter of 1956-57, Cahill registered 32 trips. ${ }^{236}$ His use of the word "trip" to track his ski season is peculiar to trail skiers and indicative of his relationship with the landscape. Alpine skiers looking to calculate the success of a particular season use "days" as the integer of choice, and

\footnotetext{
235 Backslip is when a trail skier does not have sufficient momentum or grip on his ski and the ski slides backwards instead of gripping the snow and pushing the skier uphill. It is often a quick slip on one foot, resulting in a loss of momentum and requiring the skier to regain balance.

${ }^{236}$ Harmon Cahill. Unpublished Diary. 1956-1968. In the possession of Mark Dagenais.
} 
they did not keep ski journals to the same extent as trails skiers. ${ }^{237}$ Cahill skied long distances, combining several trails and loops into his trips. His relationship with the space combined aspects from both the experiential and recreational scenarios of Bale's geographical application of Eichberg's "trialectic." Cahill's long trips were a test of physical fitness, took place on trails built and maintained to provide a surface designated by the consensus society of trail skiers who defined the ideal trail landscape and geography. But Cahill's trips were also eccentric; and his experience with the landscape was personal and not determined by group consensus. ${ }^{238}$ In the same way the slopes of Camp Fortune determined the Midgleys' alpine ski experience, the topography and geography of the trails shaped the recreation and physical education of Cahill and other trail skiers. Cahill was not alone in his numerous trips through Gatineau Park, he often skied with the second Trail Marker, Ferdie Chapman.

In January 1957, Michael MacConaill, a young man from Cork, Ireland, ran into the pair while skiing on the Skyline Trail. "I meet these two people busy clearing fallen stuff off the trail. So I stop and chat and give a hand, and take a couple of pictures. So, that was my introduction. Later on at Fortune Lodge we got talking and Ferdie sort of got me around into the thing and a little more trail skiing than I had done.”239 This meeting on the narrow Skyline Trail brought MacConaill into the social community of trail skiing.

At the time, MacConaill was relatively new to Ottawa. He picked up skiing during his first winter in Canada after becoming dissatisfied with the opportunity presented by ice-skating as a winter activity. He learned about the OSC and the strong

237 Of the skiers I interviewed, and in the records I found, only trail skiers kept accurate journals of their ski season. Michael MacConaill and Harmon Cahill both kept journals, so did trail skier and editor of the Ottawa Ski Club Yearbook James Patrick. Arnold and David Midgley kept no such records.

238 Bale, Sports Geography, 9; Eichberg, Body Cultures, 125.

239 Michael MacConaill, interview by author, November 13, 2013, Gatineau, QC, digital recording. 
local skiing community from the Ottawa Journal, and decided to equip himself with skis, boots, and poles from Heggtveit's ski shop on Sparks Street; the whole kit cost him somewhere around $\$ 100.00$ in 1956 . The skis he purchased were wooden and used a cable binding that was adjustable for either hill or trail skiing. ${ }^{240}$ Although the hills at Camp Fortune became increasingly specialized, and competitive alpine skiers used metaledge skis, the general public still used "multi-purpose" equipment equally suited to hills or trails.

After a few attempts on small hills at Strathcona Park and the Central Experimental Farm in Ottawa, MacConaill took the bus from Laurier Street directly to Camp Fortune, to further develop his skills. "This was the obvious thing: you have to get your legs on the slopes, and slalom type skiing is the way to do that," MacConaill explained. By this time, there was no need for skiers to travel by trail before reaching the slopes and tows of Camp Fortune. Gatineau Park space had been reconfigured to allow skiers of all skill levels to learn appropriate ski techniques before heading out onto the trails. MacConaill "skied mostly on the Peewee hill until I really got the feel of things," and spent the winter of 1956 perfecting his alpine technique before deciding to explore the trail network the following winter, when he bumped into Cahill and Chapman on the Skyline.

With the purchase of his 1957 OSC membership, MacConaill received a trail map (Figure 9) that encouraged skiers to explore the Gatineau Hills and showcased the club's sprawling infrastructure that offered "All Facilities in a Skier's Paradise." Upon first glance, the young Irishman could not believe the map's depiction of Gatineau Park: "It

240 Michael MacConaill, interview by author, November 13, 2013, Gatineau, QC, digital recording. 
was flat!" His education in the British Isles accustomed him to topographic "contour maps," and the lack of accurate depiction of Gatineau Park's landscape struck the pharmacologist. Although the 1957 map depicted trails, hills, and lodges in relation to one another with names, shapes, and symbols, the image was not grounded in the topographic reality MacConaill expected from a map. ${ }^{241}$ Over the course of the next decade, he undertook a mapping project along with other OSC members that resulted in a topographic map of the trail network that depicted both old and new trails (figure 10). Maps were important to trail skiers who roamed over one hundred kilometers of trails scattered throughout the park.

The OSC map categorized the types of roads and trails that littered the area. There were motor roads, wagon roads, year-round trails, winter trails, and the Ridge Road, and the cleared slopes of Camp Fortune were outlined, too. The map portrayed the area as a year-round recreational space, with the image of a canoeist on Kingsmere Lake. Cahill's diaries tell the story of a man who used the area year-round, as he compiled a record of canoe trips in the region, but he did not venture to Kingsmere Lake, as the small, isolated lake primarily served local cottagers. ${ }^{242}$ Although alpine ski areas are depicted as "clearings" on the map, there is yet no differentiation between Camp Fortune and the Trail Network. The ski network of hills and trails remains permeable, and most of Cahill's trips began and concluded at Kingsmere, with a stop at Fortune Lodge for lunch. Automobile access is an important part of the 1957 map, as cars are depicted on Kingsmere and Booth Roads, and the "Parking area for 1500 cars" at Camp Fortune is

\footnotetext{
241 Michael MacConaill, interview by author, November 13, 2013, Gatineau, QC, digital recording. 242 Harmon Cahill. Unpublished Diary. 1956-1968. In the possession of Mark Dagenais. Cahill primarily canoed on the Ottawa and Gatineau Rivers, and did not record any trips to Kingsmere Lake.
} 
clearly pointed out. The map depicts a bustling ski network in 1957, for hill and trail skiers.

Hill skiers did not explore the reaches of the trail network in search of adventure and physical fitness. They sought a different experience from the Gatineau Hills: one that was best catered to by the mechanical lifts and manicured slopes at Camp Fortune. The recreational and competitive space of hill skiers was more vertical than horizontal. Alpine skiers attempted to cover as much vertical terrain as possible in a day of skiing, repeatedly doing laps of a handful of slopes; racers frequently spent entire days skiing only the Slalom course while honing their technique. ${ }^{243}$ Hill skiers' relationship with Gatineau Park was confined to the gravity fed circuits of lifts and hills at Camp Fortune. An already developed alpine racing program made the hills of Camp Fortune an "achievement space" for competitive skiers, and simultaneously a "recreational space" for the general skiing population. Regular competition and the need to develop style drove alpine skiers to repeatedly complete descents on the same hill. ${ }^{244}$ Their satisfaction lay in the minutia of the physical side of skiing at speed, validated in competition when pitted against the clock and their peers. ${ }^{245}$ Not all hill skiers were devoted to perfection, speed and style, and the needs of competitive skiers were not the only thing shaping the development of Camp Fortune's monocultural sportscape. ${ }^{246}$

Andrew Denning applied Bale's concept of a monocultural sportscape to the ski resorts of the Austrian Alps. Bale originally used the term in reference to spaces

\footnotetext{
243 Arnold Midgley, interview by author, September 25, 2013, Ottawa, ON, digital recording.

244 Coleman, Ski Style, 78. Coleman explained the importance of developing proper ski technique in this period of alpine skiing.

245 Arnold Midgley, interview by author, September 25, 2013, Ottawa, ON, digital recording.

246 Bale, Sports Geography, 131. Bale uses the term "monocultural sportscape" to describe landscapes that have been transformed to the point that they only suit one use, in the case of Camp Fortune, alpine skiing.
} 
constructed for the sole purpose of a particular sport: the stadium, golf course, and ski jump. Denning took the concept further, suggesting that the work of "piste gardiners" to sculpt imported snow into an alpine ski race course effectively transformed the hillside into a monocultural sportscape. ${ }^{247}$ The massive development of hill-skiing infrastructure at Camp Fortune, with snowmaking, grooming, and a continuously expanding skiable surface, transformed the formerly multi-purpose space catering to trail and hill skiers into a monocultural space designed specifically for the needs of alpine skiers. This transition was not yet complete at Camp Fortune in the late 1950s, as Cahill's diaries still record trips from Kingsmere to Camp Fortune and back, but the eventual separation of crosscountry and alpine spaces was rooted in the increasingly monocultural nature of Camp Fortune. $^{248}$

For the season of 1958, Camp Fortune bolstered its mechanical lift service with a second Tbar on a hill suited to the less skilled members of the alpine community. OSC president George McHugh explained how older and less experienced skiers' demands for easier and more accessible slopes motivated these developments. ${ }^{249}$ With club membership nearing the 5,000 mark, and many inexperienced skiers among them, the OSC provided user-friendly Tbar access and gentle slopes on the newly widened Herbert Marshall Hill. This temporarily appeased members' demands for new beginner and intermediate terrain. ${ }^{250}$ The club also invested in a new chalet at the foot of the recently improved surface of the Viscount Alexander Hill, and adorned the building with the same

\footnotetext{
247 Denning, "From Sublime Landscapes to 'White Gold,"” 81.

248 Harmon Cahill. Unpublished Diary. 1956-1968. In the possession of Mark Dagenais.

249 George McHugh, "Presidential Comment," Ottawa Ski Club Yearbook 1957-58, (Ottawa: Ottawa Ski Club Publication, 1958), 13. http://gvhs.ca/digital/gatineau-park/osc/1957-1958-year-book.pdf (accessed February 19 2014).

250 James Patrick, “The Season of 1956-57," Ottawa Ski Club Yearbook 1957-58, 17. http://gvhs.ca/digital/gatineau-park/osc/1957-1958-year-book.pdf (accessed February 19 2014).
} 
name. Alexander Chalet provided a third location for alpine skiers to come in from the cold, and its inauguration by Ottawa mayor, His Worship George Nelms, attracted distinguished guests and media coverage. ${ }^{251}$

While alpine skiers and Camp Fortune continued to absorb most of club resources and attract the most new members, the trail skiing community's project to reclaim neglected trails gradually gathered steam. A large parking lot, available concessions, and a higher initial elevation than any other parking lot in Gatineau Park made Fortune Lodge the most popular starting point for trail skiers. The new lodges built for the alpine community pulled them away from Fortune Lodge; Lockeberg Lodge, Cassel Lodge, and Alexander Lodge were closer to the hills and tows. Fortune Lodge was at the west end of the valley where the cross-country trails started, convenient for trail skiers. It was also a mid-day rest spot for skiers like Cahill who routinely did more than one loop of the Merry-Go-Round or Fortune Lane. ${ }^{252}$ The Lake Trail was the most popular route for cross-country skiers leaving the valley. It followed the southern shore of Fortune Lake, and brought skiers to Keogan Lodge with minimal climbing by avoiding the steep hills of the Merry-Go-Round. Cahill and Chapman, who was director of trails for the OSC, frequently ate lunch and discussed issues of the trail network at Fortune Lodge. ${ }^{253}$ The two men assisted and oversaw the Trail Riders in their maintenance jobs and boosted

\footnotetext{
251 James Patrick, "Official Opening of the Alexander Chalet," Ottawa Ski Club Yearbook 1957-58, 54. http://gvhs.ca/digital/gatineau-park/osc/1957-1958-year-book.pdf (accessed February 19 2014).

252 Harmon Cahill. Unpublished Diary. 1956-1968. Cahill recorded numerous days when trails leading into Fortune were skied more than once: "Two rides down Canyon," "Lake Trail twice back to Fortune," "two rounds up Switzerland" (all in January of 1957).

253 Michael MacConaill, interview by author, November 13, 2013, Gatineau, QC, digital recording.
} 
enthusiasm for trail skiing in general by encouraging members to use the network at their disposal in the club's annual publication. ${ }^{254}$

While few new trails were built, the overall maintenance of the network improved in the 1950s as the Trail Riders became more organized and experienced in their work. The Trail Riders continued to cross-check and set tracks, concentrating their efforts on the Merry-Go-Round, Highland, Frank's, and Nature Trails. The FDC improved Ridge Road during the summer, and its role as the primary east-west conduit of the trail network persisted.

In an effort to improve the trail experience and return the park to its perceived natural flora of coniferous trees, John Blair and a group of St. Matthias scouts transplanted roughly 500 evergreens from the Wakefield area, twenty kilometers north of Camp Fortune, to woods along OSC trails. ${ }^{255}$ The aesthetic appeal of the Gatineau Hills was important to cross-country skiers because the trails brought them in intimate contact with forests surrounding the narrow trails, at much lower speeds than alpine skiers. Coniferous trees offered superior shelter from the wind and their dense cover gave trails a feeling of quiet austerity, making them the variety of choice for trail skiers. Trees also provided shade from the sun during the spring melt; extending the season into late April, even after the snow on the slopes of Camp Fortune had melted. Tree cover on the trails allowed Cahill to make two trips from Kingsmere to Camp Fortune and back, along Little Switzerland and Franks Trail on April $15^{\text {th }}$ and $16^{\text {th }}$ of 1960 , after OSC weatherman F.W.

\footnotetext{
254 Don Welch, “Trail Riders Report," Ottawa Ski Club Yearbook 1957-58, (Ottawa: Ottawa Ski Club Publication, 1958), 46. http://gvhs.ca/digital/gatineau-park/osc/1957-1958-year-book.pdf (accessed February 19 2014).

255 John Blair, "Ever Green," Ottawa Ski Club Yearbook 1958-59, (Ottawa: Ottawa Ski Club Publication, 1959), 39. http://gvhs.ca/digital/gatineau-park/osc/1958-1959-year-book.pdf (accessed 3 March 2014).
} 
Baker declared snow coverage at Camp Fortune "\%100 gone by April 14th." ${ }^{256}$ The Trail Riders also appreciated the aesthetic experience of tree-lined trails, as John Brown described in 1959, "it is always a thrill to be first on the trail and gaze, beauty struck, at the boughs of trees iridescent with new snow, and to watch as they snap upright again at the touch of a ski pole." 257

The Trail Riders became more organized under the guidance of Chapman, and the enthusiastic leader managed them more effectively in 1958, a year of innovation for the group. They split the fall work into a Saturday and Sunday shift, no longer staying overnight at Camp Fortune, and they began hiding tools in the woods at strategic points where snowdrifts required the shoveling of high snows in winter. Snow shoes became part of the Trail Rider's tool kit: the shoes excelled on narrower downhill sections where six to seven foot skis were too long and cumbersome for traditional cross checking. ${ }^{258} \mathrm{~A}$ section of Frank's Trail, left unattended for a few seasons, was rescued from the encroaching wilderness, and offered skiers heading from Camp Fortune to Kingsmere an alternative to the popular hills of the Highland Trail, or the less exciting Ridge Road. ${ }^{259}$ The revolving trail maintenance schedule, the assignment of small teams to specific cross-checking and track setting duties, and the use of more tools combined to modernize

256 F.W. Baker, “The Weatherman Reports,” Ottawa Ski Club Yearbook 1960-61, 13. . http://gvhs.ca/digital/gatineau-park/osc/1960-1961-year-book.pdf (accessed 4 March 2014). Harmon Cahill. Unpublished Diary. 1956-1968. In the possession of Mark Dagenais. Cahill skied on April $15^{\text {th }}$ and $16^{\text {th }}$ in 1960.

257 John Brown, "Trail Rider Report,” Ottawa Ski Club Yearbook 1958-59, 47-48. http://gvhs.ca/digital/gatineau-park/osc/1958-1959-year-book.pdf (accessed 3 March 2014).

258 Workers at Camp Fortune had been using snowshoes for years, and may have inspired the Trail Riders. ${ }^{259}$ Ferdie Chapman, "Keeping our Trails on the Rails," Ottawa Ski Club Yearbook 1959-60, (Ottawa: Ottawa Ski Club Publication, 1960), 27. http://gvhs.ca/digital/gatineau-park/osc/1959-1960-year-book.pdf (accessed 11 February 2014). This section of trail, running parallel to Ridge Road on the south side, was mislabeled on the 1957 OSC map, as part of the Nature Trail, which lies further to the west. The FDC map of the same year, however, correctly identified the section of trail as Frank's. 
trail skiing infrastructure, improve the trail skiing sports spaces, and solidify group identity.

Among the Trail Riders' responsibilities was the supervision of weekly crosscountry ski races put on by the club, and the planning of more serious provincial and national level events. Cross-country ski racing had always been part of the club's activities, but in the late 1950s racing began influencing the Trail Riders' expansion of the network. As in the alpine community, competitive cross-country racers pushed their personal limits and the limits of their equipment in competition, creating their own achievement oriented body culture. ${ }^{260}$ Recreational skiers benefitted from the improvements to the trail network brought on by racing. The club's 10-mile race course used a combination of trails, and, as the common stage for competition, received greater attention from the Trail Riders. The club's most popular race course started from Fortune Lodge, on the Western Trail, then went as far west as the Ramparts before looping back to the Ridge Road and a section of the Merry-Go-Round. Cross-country racing, however, did not rely as heavily on technique and style; although these were important, the long duration and demanding climbs of cross-country skiing made physical strength and conditioning essential. MacConaill recalled that two exceptional cross-country ski racers relocated to the region in order to train on the OSC's trail network in the Gatineau Hills. The increased responsibilities of the Trail Riders and a re-emergence of regular crosscountry races represented a general rebirth in interest for trail skiing, no doubt sparked by

260 Eichberg, Body Cultures, 124. 
OSC newsletter publication, the proliferation of maps throughout Ottawa sports stores, and a "more general interest in physical activity."261

As a growing race community emerged within the OSC ski community as a whole, the value of competition in the alpine discipline was recognized in club publications. Bud Clark, president of the Canadian Amateur Ski Association, validated the role of achievement sport in the OSC community. He posited, "The overall standard of a sport is invariably governed by the interest and development of its competitive branch. The competitive phase of a club's operation is much the same as the Advertising Department of a business. ${ }^{" 262}$ Referring to the club's unparalleled record of selection for the Canadian National Alpine Team, he pointed out the value of competition in the production of a strong community. The pursuit of competitive excellence increased demand for modern ski technology, race development programs, and adequate facilities. OSC publications from 1956 to 1967 reflected the club's general movement towards hill skiing concentrated at Camp Fortune and the doubling of club membership.

In order to compete at the highest level, athletes required the appropriate 'achievement space,' in the form of training facilities and consistent access to adequate snow conditions. Infrastructure at Camp Fortune was installed to satisfy the needs of racers. The winter of 1958 saw the first piles of man made snow on the hills of Camp Fortune. After making a trip to the northeastern United States in the fall, John Clifford decided that in order for Camp Fortune to offer the type of manicured ski surface modern alpine skiing required, it was necessary to control the amount of snow on the hills.

\footnotetext{
261 Michael MacConaill, interview by author, November 13, 2013, Gatineau, QC, digital recording. 262 W.G. Bud Clark. "A Message from the President of the Candian Amateur Ski Association," Ottawa Ski Club Yearbook 1957-58, (Ottawa: Ottawa Ski Club Publication, 1958), 58. http://gvhs.ca/digital/gatineaupark/osc/1957-1958-year-book.pdf (accessed February 19 2014).
} 
Clifford purchased a patent from Larchmont Engineering for exclusive rights to the distribution of snowmaking equipment in Canada, and installed the Larchmont-designed canons on the Slalom and Pee Wee runs.

Snowmaking with this equipment consisted of pressurized air and water being shot out of a nozzle, or 'canon,' into the air as a mist. At sub-zero temperatures, the mist froze when it met the air and fell to the ground forming large mounds of dense snow. ${ }^{263}$ The "manmade" or "artificial" snow ensured a suitable surface was available for both beginners, who skied on Pee Wee, and advanced skiers, who chose the Slalom Hill. Flood lighting was also installed at Camp Fortune, allowing skiers to enjoy the slopes after dark, Monday through Saturday. ${ }^{264}$ But, once again, the needs of competitive racers continued to guide the development of new terrain at Camp Fortune, and in the ski world more generally. ${ }^{265}$

The club improved a hill outside the valley during the summer of 1958, named the Ski-Skule Downhill, located on a north facing slope that led down to Meech Road about one mile east of Dunlop's parking lot. Although the Ski-Skule run did not use the entire height of the land, the terrain in that area was better suited to learning the techniques for downhill skiing than the lower hills and more relaxed gradient of the valley slopes. Regulations of the Canadian Amateur Ski Association required a hill with a minimum of 600-vertical-feet of elevation to host a national-level alpine event, and none of the slopes on the valley side met the requirement. In order to establish a national-level development

\footnotetext{
263 Ian McLaren, “Snowmaking - What's it All About?” Ottawa Ski Club Bulletin, 1964-65, (Ottawa: Ottawa Ski Club Publication, 1965), 1. http://gvhs.ca/digital/gatineau-park/osc/1965-02-08.pdf (accessed 19 February 2014).

264 George McHugh, "Presidential Comment," Ottawa Ski Club Yearbook 1958-59, 13. http://gvhs.ca/digital/gatineau-park/osc/1958-1959-year-book.pdf (accessed 3 March 2014).

265 Andrew Denning discussed the creation of a monocultural sportscape for the alpine racing events of the winter Olympics of 1964. Denning, "From Sublime Landscapes to 'White Gold,"” 81.
} 
program at Camp Fortune, a hill of adequate size was required. The Ski-Skule lay at the foot of the solution to the problem.

The summer of 1959 saw dramatic expansion of the OSC's alpine infrastructure at Camp Fortune to solve "the main problem" that Clifford pointed out: "crowd control."266 The club paid Clifford Lifts $\$ 100,000$ for the acquisition, landscaping, and installation of lifts in the Skyline area, on the taller hills east of the valley. Skyline was the massive expansion of hills around the Ski-Skule downhill slope. The area offered 600 vertical feet of north facing ski terrain running from the highest point of the Skyline Trail and Little Switzerland down to Meech Road. The steep pitch of the new zone was ideal for competitive skiers looking to push their limits and intermediate recreational users who wished to experience longer slides than on the valley side, and because it was north facing, snow remained on the hill longer into the spring.

Skyline was equipped with a modern 1200 person-per-hour Poma-Lift, a ski patrol shack, a parking lot at the bottom of the hill, and a warming hut at the top of the hill. The new intermediate and advanced runs were completely separate from the valley side, which could be reached from Skyline on skis via Humdinger Ravine, which led to the foot of the Joe Morin Slalom, ski jumps, and Lockeberg Lodge. Physical separation between the valley, where entry-level hills offered an ideal development ground for new skiers, and Skyline, where steeper and taller hills attracted racers, reduced on-hill conflicts between skiers with polarized skillsets and spatial requirements. Skyline was created as an "achievement space" for alpine racers to produce results and records in

\footnotetext{
266 John Clifford, "Economy Skiing - Camp Fortune Style," Ottawa Ski Club Yearbook, 1961-62, 63. http://gvhs.ca/digital/gatineau-park/osc/1961-1962-year-book.pdf (accessed 20 February 2014).
} 
competition. ${ }^{267}$ The 600 vertical-foot requirement of the Canadian Alpine Ski

Association was the underlying reason the club chose to develop advanced terrain rather than increase their recreational facilities. Camp Fortune was selected to host the 1960 Canadian Alpine Championships in recognition of the important local racing culture of the OSC. ${ }^{268}$

The valley side of Camp Fortune received improvements of its own in preparation for the 1960 ski season. The former Pink Lake Lodge was relocated to the bottom of the Pinault Hill, where it was renamed the Cassel Lodge and equipped with a canteen; parking in the valley could now accommodate 1500 cars; and two new rope tows were installed, one to serve beginners on the Pee-Wee hill and the other on "the widened and graded Malcolm Macdonald Slope. ${ }^{" 269}$ With the Skyline sportscape catering specifically to the needs of intermediate and expert skiers, complete with its own lodges and first aid facility, the valley side of Camp Fortune was tailored for the huge demands of new skiers and the growing ski school crowds. In Ottawa, "skiing was the thing to do" according to MacConaill. The public perception of skiing as the social norm for winter activity certainly contributed to the droves of people who picked up the sport and tried out the slopes of Camp Fortune. ${ }^{270}$

In the 1960s, skiing was the thing to do in a number of places in North America, and recent works by Hal Rothman, Annie Gilbert Coleman, Duke Ritchey, and Michael Childers explore how the ski boom of the American West, notably Colorado, transformed the mountain landscape there and gave new meaning to towns like Aspen that lost their

\footnotetext{
267 John Bale, Sports Geography, 9.

268 John Clifford, "The Ottawa Ski Club Expands," Ottawa Ski Club Yearbook 1959-60, 51. http://gvhs.ca/digital/gatineau-park/osc/1959-1960-year-book.pdf (accessed 11 February 2014). 269 Clifford, "The Ottawa Ski Club Expands," 51.

270 Michael MacConaill, interview by author, November 13, 2013, Gatineau, QC, digital recording.
} 
"bohemian rural quirkiness" and became modern resort towns. ${ }^{271}$ From 1960 to 1970 , skier visits to Aspen increased by $900 \%$, and the previously bucolic mountain town, home to farmers and free-spirits, evolved into a modern resort town, and an influx of wealthy developers created tensions between the old and new residents of Aspen, garnering national interest. ${ }^{272}$ Childers showed the growing trend of ski resort development throughout Colorado and situated the transformation of the landscape within broader protectionist movements and a reconfiguration of how the US National Forest Service regulated ski areas. He explained that the term "Aspenization" represented all of the negative aspects of skiing as the process transformed previously unique towns into a marketable brand of ski resorts. ${ }^{273}$ Camp Fortune's diminutive elevation, thousands of feet less than the Rocky Mountains in Aspen, and proximity to Ottawa and Hull where people could earn a living from industries outside skiing, protected it from developing into a destination resort. But an international postwar alpine ski boom affected the landscape of the Gatineau Hills, nonetheless, as the space was transformed into a different type of modern ski hill to accommodate the crowds. ${ }^{274}$

Coleman identified two forms of alpine ski communities and cultures in the Rocky Mountains. In places like Aspen, wealthy urban residents espoused a European approach to skiing centered around an exclusive resort culture as discussed by Ritchey and Rothman. Coleman, though, pointed out that skiing was popular in rural

\footnotetext{
271 Duke Ritchey, "The Aspenization of Telluride: Coming of Age and Mythologizing Change in Ski Country, 1945-1985," Pacific Historical Review, Vol. 79, No. 2, (May 2010), 242. http://www.jstor.org/stable/10.1525/phr.2010.79.2.231 (accessed 10 October, 2013).

272 Ritchey, "The Aspenization of Telluride," 246.

273 Childers, Colorado Powder Keg, 99.

274 Denning, "From Sublime Landscapes to 'White Gold,"” 78-108; Hal K. Rothamn, "Powder Aplenty for Native and Guest Alike: Steamboat Springs, Corporate Control, and the Changing Meaning of Home," The Magazine of Western History, (Montana: 1998), 5.
} 
communities, too. Coleman argued that many Coloradans skied on small-scale, local hills, where an alternative form to resort ski culture emerged where community and participation outweighed private development. ${ }^{275}$ The OSC community of 10,000 members was the base for skiing at Camp Fortune. Although the club hired John Clifford Lifts to operate and develop most of the infrastructure, Clifford himself was part of the ski community, and was not an investor from a distant city attempting to glean profits from the ski hill. Low prices and the OSC community situated the ski experience at Camp Fortune in the early 1960s in the same realm as local clubs in Coleman's Colorado.

Leading up the 1960 Winter Olympics at Squaw Valley California, OSC newsletters trumpeted the downhill ski racing exploits of its racers. "Andy Tommy proved that he was still Canada's top skier; and in every inter-zone meet our OSC competitors were in, they succeeded in winning most of the first ten positions."276 International competition inspired competitive racers in the club to excel, and the prospect of local racing spawned a development program in the Ottawa area that doubled club membership from 5,300 in 1958 to over 10,000 in $1962 .{ }^{277}$ When asked about the exponential growth in skiing's popularity in the Ottawa area in only a few years, Midgley attributed the expansion to the forward thinking and benevolent nature of John Clifford:

That was John's doing. He wanted everybody to ski for as cheap as possible, his downfall, but it was very successful. He decided that what he needed to do was teach the kids to ski. So he got the city [of Ottawa] to provide the sites, the Citizen [newspaper] provided the buses to get the kids to the sites, John provided junior

\footnotetext{
275 Coleman, Ski Style, 81.

276 Dave Wright, “The 1957 Racing Season,” Ottawa Ski Club Yearbook 1957-58, 29. http://gvhs.ca/digital/gatineau-park/osc/1957-1958-year-book.pdf (accessed February 19 2014).

277 George McHugh, "Presidential Comment," Ottawa Ski Club Yearbook 1958-59, (Ottawa: Ottawa Ski Club Publication, 1959), 13. http://gvhs.ca/digital/gatineau-park/osc/1958-1959-year-book.pdf (accessed 3 March 2014); George McHugh, "The President's Message," Ottawa Ski Club Yearbook 1961-62, (Ottawa: Ottawa Ski Club Publication, 1962), 7. http://gvhs.ca/digital/gatineau-park/osc/1961-1962-year-book.pdf (accessed 20 February 2014).
} 
instructors from Camp Fortune Ski School, who took over the teaching of these kids. The ski club went from six or seven thousand members to fifteen thousand members, as a direct result of that. Because the kids wanted to go skiing and they brought their parents out, and instead of standing around, they went skiing. ${ }^{278}$

Junior instructors taught younger children the fundamental skills of edge control, turns, balance, and stopping, skills they had mastered themselves at Camp Fortune from senior instructors of the Ski School there. Swathes of beginner and intermediate skiers in the development programs pressured the club to offer separate terrain for advanced skiers. Skyline proved to be an ideal spatial release valve, and experienced skiers and competitive racers took pride in the area's potential as a training ground for budding racers. The Olympic Gold Medal Anne Heggtveit won at Squaw Valley in 1960, validated the racing legacy of the OSC and Camp Fortune's potential for shaping champions on the world stage.

The Heggtveit name was synonymous with skiing in the National Capital Region, and Anne Heggtveit benefitted from her family's skiing lineage. Her father, Halvor, and uncle, Bruce were both Dominion cross-country skiing champions. Anne learned to ski before she was two years old, on the hills of Rockliffe Park. Only a few years later, "the daring six-year-old youngster created a stir that echoed the length and breadth of the Laurentian ski territory" after photographers and journalists witnessed the child's impressive ability on the slopes of St. Sauveur. ${ }^{279}$ The young Heggtveit had been winning ski races since she was old enough to compete, and even won the Gatineau Zone ladies

278 David Midgley, interview by author, November 12, 2013, Gatineau, QC, digital recording.

279 James S. Patrick, "Anne Heggtveit," Ottawa Ski Club Yearbook 1945-46 (Ottawa: Ottawa Ski Club Publication, 1946), 80. http://gvhs.ca/digital/gatineau-park/osc/1945-1946-year-book.pdf (accessed 18 March, 2014). 
championship in slalom and combined at only seven years old. ${ }^{280}$ In 1958, the OSC recognized Heggtveit's international success, organizing a reception and luncheon for her, where club president McHugh presented her with a silver tray, and Ottawa Mayor Nelms a bar to the Civic Crest she had received in $1953 .{ }^{281}$ In 1959, Heggtveit was the first non-European to win the Arlberg-Kandahar combined championship in Garmisch, West Germany. Carrying the momentum from her win in West Germany to the Olympics in Squaw Valley, Heggtveit was the first Canadian woman to win gold in alpine skiing. ${ }^{282}$

Two seasons after Heggtveit's golden performance, OSC membership reached the 10,000 mark, and John Clifford Lifts installed the first chairlift at Camp Fortune, on Skyline. ${ }^{283}$ The chairlift made the trip uphill safer and a great deal more comfortable for skiers, because they could sit down on the way up, instead of straddling the disc of the Poma and sliding standing up. Skiers expended more of their energy on the hills, doing more runs, and skiing with more power. The club cleared a new slalom hill running along the east side of the new chairlift, named in honour of the club's most successful slalom racer, "Heggtveit."

The growth of membership increased traffic on the slopes and trails to unforeseen levels, and the number of injuries followed suit. The St John Ambulance patrol staff was responsible for first aid throughout the recreational area of the Gatineau Zone.

Headquartered in Old Chelsea and in the main parking lot of Camp Fortune, the volunteer patrollers responded to calls throughout the Gatineau Hills. Some of the lodges on the

\footnotetext{
280 Jim McAuley, The Ottawa Sports Book: Vignettes from Ottawa's Sport History, (Burnstown: General Store Publishing House Inc, 1987), 338.

281 James S. Patrick, "Reception for Anne Heggtveit," Ottawa Ski Club Yearbook 1958-59, 62. http://gvhs.ca/digital/gatineau-park/osc/1958-1959-year-book.pdf (accessed 3 March 2014).

282 McAuley, The Ottawa Sports Book, 339.

283 George McHugh, "The President's Message," Ottawa Ski Club Yearbook 1960-61, 9. http://gvhs.ca/digital/gatineau-park/osc/1960-1961-year-book.pdf (accessed 4 March 2014).
} 
trail network were equipped with rudimentary direct line communication to other cabins and the St John Ambulance headquarters. Upon receiving a call, patrollers usually skied out to the location of an injured person, pulling purpose built toboggans to carry skiers to safety. In response to the ski boom of the late 1950s, the volunteer patrol service increased their fleet of toboggans to 14 . The season of 1959-60 saw the Ambulance staff responding to over 400 reported injuries in the Gatineau Zone. ${ }^{284}$ Explaining the location of an injured skier on the sprawling network by radio was a logistical problem that needed to be addressed. To overcome the issue of deciphering the rich linguistic landscape of the trail network, Chapman suggested certain hills be numbered and indicated on trail-maps in order to better communicate the location of injuries. Maps of Gatineau Park began to include numbers on them at specific points where injuries commonly occurred (a steep hill or sharp turn). These hills and turns, however, often already had names. Although the trail names remained, numbers replaced names like "Dock n Doris" or the "Highland Fling." This marked the first time numbers replaced names to facilitate managerial responsibilities by identifying and ordering park space, but it would not be the last. ${ }^{285}$

Increased traffic was not the only factor contributing to a marked increase in injuries. Many new skiers learned how to navigate the slopes of Camp Fortune on outdated skis not equipped with modern safety features. Traditional alpine ski bindings fixed the ski boot directly to the ski by clamping the heel and toe securely to maximize control and balance. The more secure the connection between boot and ski, the more

\footnotetext{
284 Gary Perkins, “Gatineau Zone Ski Patrol Report,” Ottawa Ski Club Yearbook 1959-60, 40. http://gvhs.ca/digital/gatineau-park/osc/1959-1960-year-book.pdf (accessed 11 February 2014).

285 Joseph Woods interview. Joseph explained how the use of numbers to replace trail names in the 1970s was partially for managerial reasons, and largely to address concerns about the use of English language signs in a francophone province.
} 
power a skier could put into a turn, generating more speed and superior control.

Competitive racers like Arnold Midgley used a binding style that bound the foot to the ski with a leather strap tied tightly to loops on the ski. Midgley carried a small pocketknife at all times in order to free a twisted leg from his boot in the event of a crash. ${ }^{286}$ Some hardline skiers refused to embrace changes in equipment for fear of lost performance.

By 1959, an estimated 700,000 Canadians owned alpine skiing equipment, and 9,000 skiers visited Camp Fortune that winter. The OSC published these statistics, produced by the Continental Casualty Company who rated skiing as an "unusual risk" activity, in the same category as rodeo riding and contact football. ${ }^{287}$ Unlike other sports with a high risk of injury, alpine skiing was accessible to anyone capable of acquiring skis, be they borrowed, rented or purchased second hand, and the low price of skiing at Camp Fortune made it even more accessible

Very few novice skiers possessed the fundamental skillset required to control their skis. Numerous injuries to beginners threatened the sport's growth and pushed companies to develop technology to make the sport safer. Safety bindings that automatically released the foot when enough twisting pressure was put on it freed the ski and saved a person's leg from serious injury. These 'safety' bindings made skiing much safer. As with any new technology, there was resistance to the new bindings for their cost, weight, complicated nature, and difficulty of adjustment, as well as a perceived

\footnotetext{
286 Arnold Midgley, interview by author, September 25, 2013, Ottawa, ON, digital recording. 287 W.L. Ball, "How Effective are Release Bindings?” Ottawa Ski Club Yearbook 1959-60, 43. http://gvhs.ca/digital/gatineau-park/osc/1959-1960-year-book.pdf (accessed 11 February 2014).
} 
inferiority to traditional bindings by competitive racers. ${ }^{288}$ However, comparison testing and convincing statistics promoted the undeniable safety advantages of the new technology, and, as the equipment grew more refined, the ski community accepted them. On the alpine side, the ski patrol registered a marked decrease in injuries for the season of 1960-61. In one year, injuries dropped by almost $24 \%$, from the highest recorded total of 534 to 408 , the standardization of release bindings immediately affected total injuries. ${ }^{289}$ In the season of 1960-61, the OSC charged an annual fee of $\$ 50.00$ for an adult "All Tows Pass," and \$25.00 for the "Rope Tows Pass," which gave skiers unlimited access to the tow services provided by John Clifford Tows. John Clifford Ski Tows was responsible for the operation and construction of rope tows, Tbars, and chairlifts, as well as the maintenance of the skiable surface in winter. Clifford installed snow-making machines to ensure skiing regardless of poor snowfalls, purchased and maintained expensive "groomers," purpose built heavy machinery that created a consistent and level ski surface, to offer the best possible ski conditions. In exchange for exclusive rights to lift operations, Clifford gave the OSC $2 \%$ of his gross receipts. ${ }^{290}$ The OSC footed the bill for lodge construction and furnishing, clearing and grading alpine slopes in summer, building and maintaining the Lockeberg Jump, and expanding parking lots for the growing number of visitors.

The artificially deflated price of skiing at Camp Fortune was the result of a relationship between Clifford and the OSC, and both groups' underlying goal of

\footnotetext{
${ }^{288}$ W.L. Ball, “How Effective are Release Bindings?” Ottawa Ski Club Yearbook 1959-60, 43. http://gvhs.ca/digital/gatineau-park/osc/1959-1960-year-book.pdf (accessed 11 February 2014). 289 Gary Perkins, "Ski Patrol and First Aid Report 1960-61," Ottawa Ski Club Yearbook, 1961-62, 23. http://gvhs.ca/digital/gatineau-park/osc/1961-1962-year-book.pdf (accessed 20 February 2014). 290 Bob McGiffin (Treasurer), "The Partnership of the O.S.C. and its Concessionaires," Ottawa Ski Club Yearbook, 1961-62. (Ottawa: Ottawa Ski Club Publication, 1962), 53. http://gvhs.ca/digital/gatineaupark/osc/1961-1962-year-book.pdf (accessed 20 February 2014).
} 
providing accessible skiing to a local population. Clifford who "wanted everybody to ski for as cheap as possible" and the Executive Board of the OSC, who desired low membership fees to ensure skiing for themselves and their families remained affordable, forced the price down. ${ }^{291}$ The unrelenting development of new hills and slopes, and the persistent organization of races and social events prevented the club and Clifford from earning large profits at Camp Fortune.

David Midgley, a former Night Rider, proficient racer, and long time employee and friend of Clifford's, recalled how Clifford's approach to developing Camp Fortune caused both the artificially low price of skiing there and a comparatively low salary for Clifford. Midgley remembered "going to Blue Mountain with John, to an Ontario ski operators meeting, and he was talking to Jozo Weider, who was the head man there, and [John] said: "You know Jozo, you and I are alike, we both built ski areas from scratch, built them up, and I only take \$10,000 a year out for myself.” Jozo started laughing and said: "Yeah, it costs me \$10,000 a year to keep my daughter in France, in school!"292 John A. Stevens and Elliott Kaufmann's biography of Clifford confirmed the man's selfless relationship with Camp Fortune. "John Clifford was repaying a debt of gratitude by subsidizing Fortune's operations out of his other business revenues. He did little more than cover his costs on any construction job done within the bounds of Fortune." ${ }^{293}$ In the history of skiing in the Gatineau Hills, the influence of Clifford stretched across generations, and extended beyond the limits of Camp Fortune. Clifford was integral to

\footnotetext{
291 David Midgley, interview by author, November 12, 2013, Gatineau, QC, digital recording. 292 David Midgley, interview by author, November 12, 2013, Gatineau, QC, digital recording. 293 Kaufmann and Stevens, White Gold, 81.
} 
the construction of ski hills at Mont Ste Marie, Mont Cascades, and Mount Pakenham in the 1960 s and $70 s^{294}$

In 1962, Clifford used the OSC Yearbook as a platform to explain how fortunate skiers were to have such outstanding and constantly improving facilities on their doorstep in "Economy Skiing - Camp Fortune Style." Therein, he explained that Camp Fortune offered night skiing six days a week, free parking on weekdays, two chairlifts, four different hills with over a dozen groomed runs combined, numerous lodges, a ski-shop, wax room, and ski patrol service, all for the modest price of $\$ 3.00$ per day. Other ski hills in the east, at Collingwood, Mont Gabriel, Mont Tremblant, and Stowe charged between \$5.00 and \$6.50 per day. David Midgley worked so hard that Clifford "provided a Viking type Chalet for our Assistant Manager/Accountant Dave Midgley so that when he is working those 18 hour days, he hasn't far to go to get home." ${ }^{295}$ Midgley recalled moving into the "A-frame" cabin Clifford had built at Camp Fortune on Labour Day weekend of 1960, where he spent a winter with his wife, who worked at the Wakefield hospital. ${ }^{296}$

The hills and lodges were not the only costly infrastructure at Camp Fortune, nor were the OSC and Clifford the only parties investing in the area. Parking lot expansion was expensive, and required considerable maintenance in winter. The Hull City Transport Company took care of the parking lots and charged a fee for weekend parking; they paid $10 \%$ of their gross profits to the OSC. By 1962, the trail network was almost entirely on Gatineau Park land, controlled by the National Capital Commission (NCC) who replaced the FDC in 1959. The NCC provided fire-fighting, built roads, and removed snow from

\footnotetext{
294 Kaufman and Stevens, White Gold, 88-89, 108, 118-119.

295 John Clifford, "Economy Skiing - Camp Fortune Style," Ottawa Ski Club Yearbook, 1961-62, 63. http://gvhs.ca/digital/gatineau-park/osc/1961-1962-year-book.pdf (accessed 20 February 2014).

296 David Midgley, interview by author, November 12, 2013, Gatineau, QC, digital recording.
} 
sections of Kingsmere Road, Meech Road, and Dunlop Road, which were important arteries for skiers looking to reach Camp Fortune or to access the trails via Kingsmere. The commission also worked alongside the Trail Riders to help improve and maintain the trail network, especially Ridge Road, which the NCC extended to the top of Luskville Falls to be used as an east-west access road. ${ }^{297}$

Despite the massive developments on the alpine side of the OSC, trail skiing received special attention in the early 1960s. Chapman described the efforts of the Trail Riders to deal with tremendous snowfalls in February, and snowshoes proved they were a valuable alternative to cross-checking in deep snow. ${ }^{298}$ The Trail Riders undertook serious work in the fall to remove heavy trees that had obstructed the Highland and Merry-Go-Round trails for several seasons following a storm in the summer of $1952 .{ }^{299}$ "A program for putting the trails back on their original lines was started this spring through the voluntary efforts of the trail committee. Diversions, caused by heavy trees that had come down over the years, required correction. It is hoped that most of these detours will have been cleared up before the ski season begins and that improvements will be complete." ${ }^{300}$

Michael MacConaill was with the Trail Riders that season, and recalled how the original group of volunteers "had included some more mature young adults" but had dropped off in the early 1950s to just the "high school boys." When they confronted with

\footnotetext{
297 Bob McGiffin (Treasurer), "The Partnership of the OSC and its Concessionaires," Ottawa Ski Club Yearbook 1961-62, 53. http://gvhs.ca/digital/gatineau-park/osc/1961-1962-year-book.pdf (accessed 20 February 2014).

298 Arnold Midgley, interview by author, September 25, 2013, Ottawa, ON, digital recording.

299 Michael MacConaill, interview by author, November 13, 2013, Gatineau, QC, digital recording.

300 Ferdie Chapman, "Trail Skiing," Ottawa Ski Club Yearbook 1960-61, 11.

http://gvhs.ca/digital/gatineau-park/osc/1960-1961-year-book.pdf (accessed 4 March 2014).
} 
the task of removing the large trees, "they really could do nothing about it." ${ }^{301}$ In 1960 , with the help of a crosscut saw, and the experienced hand of another volunteer, MacConaill and the Trail Riders returned many sections of trail to their original lines after almost a decade of skiers being forced to skirt around the fallen trees that blocked the natural flow of the trail. That year, the Trail Riders increased their strength from 20 to 25 volunteers, and reinstated a long abandoned tradition of evening patrols along popular ski routes like the Merry-Go-Round. ${ }^{302}$ Increased efforts on the maintenance of the trails reflected "the growing number of trail skiers" the club reported in a special bulletin in 1961. ${ }^{303}$ MacConaill recalled that "people in the early 1960s were beginning to get more interested in getting exercise, and, so trail skiing did build up a bit."304

The 1962 OSC Yearbook noted a reemergence of trail skiing, likely due in part to the tireless work of Chapman, Cahill, MacConaill, and the Trail Riders. Chapman's "Meandering on the Trails," gave an account of the cross-country trail network from the skier's perspective. Fortune Lodge was still the main starting point. Skiers were reminded that the Merry-Go-Round loop led to McCloskey and Keogan's Lodges which offered pots and pans for skiers looking to refuel while out on the trail, or simply take a break in the warm glow of a cast-iron stove. A new trail named Chicken Run was cut in the fall to help novice skiers enter the network west of Camp Fortune without having to climb the steeper slopes of Bonnie Brae or Fortune Lane. ${ }^{305}$

\footnotetext{
301 Michael MacConaill, interview by author, November 13, 2013, Gatineau, QC, digital recording.

302 Richard Simpson, "Trail Rider Report," Ottawa Ski Club Yearbook 1960-61, 13. . http://gvhs.ca/digital/gatineau-park/osc/1960-1961-year-book.pdf (accessed 4 March 2014).

303 Ottawa Ski Club, Ottawa Ski Club Bulletin, No.1, (1960-61), 1. http:/gvhs.ca/digital/gatineaupark/osc/1960-1961-1.pdf (accessed 20 February 2014).

304 Michael MacConaill, interview by author, November 13, 2013, Gatineau, QC, digital recording.

305 Ferdie Chapman, "Meandering on the Trails," Ottawa Ski Club Yearbook 1961-1962, 17-19.
} 
The Trail Riders concentrated their efforts in the early 1960s on the construction and reconstruction of trails in Gatineau Park west of Camp Fortune. After clearing the trails in the Kingsmere-Camp Fortune area, MacConaill "asked if there were any other old trails we could re-open. So we started off out in the west for a little while there." MacConaill explained, "Western [Lodge] had been abandoned and taken in in the early 40s and used to make Lockeberg [Lodge]." ${ }^{306}$ So there wasn't a lodge in the western end of the network for skiers to seek refuge, causing the trails to fall into disuse. With the goal of improving their cross-country race course, the Trail Riders performed rare winter trail clearing on the Burma Road in February 1961. Located west of the Kingsmere-Camp Fortune area, and not featured on the 1957 OSC map, the original Burma Road ran north south connecting the Western Trail to the Ramparts Lookout, overlooking Meech Lake. MacConaill and some of the Trail Riders found from a day of "bushwacking" east of the Burma Road that "there was enough road there that we could continue our Burma Road from the Ramparts and bring it in all the way, after which we could use it for our race."307 MacConaill's reference here to there being "enough road there," suggests a long abandoned section of road left behind by the farms. On the 1931 map, the farming road named Alexander's ran perpendicular to where the Burma Road was cleared as a ski trail in 1960, it is likely the remnants of road MacConaill saw were part of an old logging road. Farmers felled trees from their woodlots in winter, and dragged logs out by horse through the snow. The line of mobility originally built for winter work became reappropriated and improved for the play of skiers. With the clearing of the Burma Road, there were now two routes extending west of the Fortune Parkway, and the resurging trail

\footnotetext{
306 Michael MacConaill, interview by author, November 13, 2013, Gatineau, QC, digital recording. 307 Michael MacConaill, interview by author, November 13, 2013, Gatineau, QC, digital recording.
} 
skiing community used them to access a different type of experience compared to the older trails built by the Night Riders in a different era of skiing.

The trails in the Kingsmere-Camp Fortune area, the Highland Trail, Canyon Trail, Little Switzerland, Merry-Go-Round, Frank's, George's and the Skyline Trail, were all built before mechanical lifts created the distinction between trail and hill skiers and bound the alpine group to the monocultural sportscape at Camp Fortune. ${ }^{308}$ These old trails featured several steep hills, and often prioritized frequent changes in elevation over exploration. The descents on these trails sent skiers hurtling through the woods at tremendous speeds and navigated park space in search of peaks and hills for the gravity fed slides they provided. These older trails gave similar sensations to the large cleared slopes at Camp Fortune, and the Night Riders who cleared them naturally migrated to Camp Fortune and played an important role in the development of hill skiing there following the installation of the first rope tows. ${ }^{309}$

The western trail network also sought out peaks and hills, but for different reasons. The aesthetic value of looking out over the Ottawa Valley from the Western Lodge or Champlain Lookout to the south, or from the Ramparts over Meech Lake to the north attracted Chapman, Cahill, and MacConaill to the comparatively undeveloped western area. Trails built in this new age of cross-country revival followed lines that harnessed the spirit of "oldtimer" skiing, the loss of which had been so lamented during the initial postwar boom of hill skiing at Camp Fortune. The Trail Riders development to the west of Camp Fortune made the "oldtimer" skiing experience of "long, velvety glides

\footnotetext{
308 Bale, Sports Geography, 131.

309 The Trail Riders were created in 1947, the year after John Clifford's first rope tow at Camp Fortune, to maintain the trail network the Night Riders already neglected in favour of the wide slopes of Camp Fortune.
} 
down woodland slopes; the sometimes exhausting yet satisfying climbs to gain the altitudes from which to glide once more" available once again. This type of skiing was more horizontal than trips along the trails surrounding Camp Fortune. ${ }^{310}$ Burma Road, the reinvigorated Western Trail, and Hidden Valley navigated less tumultuous topography than the old trails cut by the Night Riders, and pushed into new areas of Gatineau Park outside the scope of the 1957 OSC Map (Figure 9). The Trail Riders created a network of mobility that allowed them a sense of adventure and exploration, while serving as suitable race trails, too. The topography of the old trails made them unsuitable as crosscountry race courses, and the development into the west reflected the modern needs of cross-country ski racing, which MacConaill recalled as being "one-third climb, one-third descent, and one-third flat." ${ }^{311}$ As with alpine skiing, it was the racing culture that determined the development of the sport as a whole.

In 1962, Martin and Ann Aller, and their young family moved to Ottawa, and immediately took up skiing. Martin, or "Mo," recalled the family's first trips to Camp Fortune where he "got tee'd off with all the line-ups at the tows and so on, and so we started going around the trails. We started skiing in the park with downhill skis." From then on, the Allers roamed the trails as a family. Every weekend, they left their home in Nepean around 9:30am and headed to Gatineau Park for a long day of skiing. Mo, who skied cross-country competitively for decades, pushed his physical limits on solo trips: "I was training in those days. We were out skiing hard, just pushing every day you could get out there." His motivation and hard work extended to family ski trips every weekend,

310 D.L. Surveyor, "Our Day," Ottawa Ski Club Yearbook 1946-47, 54. http://gvhs.ca/digital/gatineaupark/osc/1946-1947-year-book.pdf (accessed 11 February 2014); W.S.L. "An Oldtimer Protests," Ottawa Ski Club Yearbook 1948-49, (Ottawa: Ottawa Ski Club Publication, 1949), 52. http://gvhs.ca/digital/gatineau-park/osc/1948-1949-year-book.pdf (accessed 13 February 2014).

311 Michael MacConaill, interview by author, November 13, 2013, Gatineau, QC, digital recording. 
when Ann, Mo, and their two sons Bryan and David, drove out to Gatineau Park. Mo wore a heavy pack with food, water, and supplies for the family, who skied great distances despite the cold and complaints from the children. ${ }^{312}$

On one of their weekend forays on the trails the Allers met Ferdie Chapman, who took great joy in seeing a whole family so enamoured of trail skiing. He offered the kids candy as a reward for their efforts on strenuous climbs, and no doubt the incentive helped keep the children motivated. ${ }^{313}$ The Allers, and families like them, were a novelty on the trails, which were not busy compared to the congested slopes and lift-lines of Camp Fortune. Both trail and alpine skiers still shared the space of Camp Fortune's parking lot, where the Allers parked and walked to Fortune Lodge to wax their skis before heading off into the trails. ${ }^{314}$ What they found on the network was a small community of families like theirs, surrounded by individuals and friends like Cahill, MacConaill, and Chapman. ${ }^{315}$ The Allers' memories of Gatineau Park were rooted in the sheer physicality of tackling the trail network, and the tightly knit community of trail skiers.

I think we knew all the families. Just the fact those kids of ours got so much recognition at that time, there were only the nucleus of these families where the kids were going out, and maybe some old timers, rugged individualists or loners, who would be out skiing by themselves. We were out every Saturday morning from about half past 9 , and we were gone all day. The kids and I would be crying on the trails because it was just so cold, and so much work, and the kids had blisters on their heels, because you know there was no equipment for them in those days; they were 5, 6, and 9. It was just such slugging to get up those hills. ${ }^{316}$

In the season of 1962, skiers were able to see Camp Fortune from kilometers away, even across the river in Ottawa. The center of skiing for the region could be

\footnotetext{
312 Martin Aller, interview by author, November 16, 2013, Ottawa, ON, digital recording. 313 Ann Aller, interview by author, November 16, 2013, Ottawa, ON, digital recording.

314 Martin Aller, interview by author, November 16, 2013, Ottawa, ON, digital recording.

315 Ann and Martin Aller, interview by author, November 16, 2013, Ottawa, ON, digital recording.

316 Ann Aller, interview by author, November 16, 2013, Ottawa, ON, digital recording.
} 
identified from a distance thanks to a blinking light sitting 952 feet above the top of the Slalom Hill. CFRA FM constructed a steel radio tower and access road from the parking lot near Fortune Lodge to the plateau at the top of the hill behind the Slalom Hill. ${ }^{317} \mathrm{~A}$ light at the top of the lofty tower warded off low-flying airplanes and made the tower visible at night from a great distance. The new visual landmark gave skiers on the trail network a point around which to orient themselves, although the imposing structure compromised the wilderness aesthetic of the area.

In 1964, the OSC expanded Camp Fortune's alpine slopes to another hill, this time catering to the needs of intermediate and beginner skiers. Once again, John Clifford Ski Tows was contracted for the clearing of two runs, each roughly 3,500 feet long and 75 to 100 feet in width leading from the top of the Pinault hill down a gradual northfacing slope to Meech Road, between Skyline and Dunlop. The runs were cleared on NCC land adjacent to the 315 acres owned by the OSC, so a twenty-year lease was negotiated between the two parties. ${ }^{318}$

Operators at Camp Fortune used machines as they attempted to deal with drainage problems occurring on the clearcut slopes of rocky Canadian Shield. Decades without trees' roots to keep soil from being swept away in spring created an uneven surface that required intensive alterations to be an effective foundation for the winter skiing surface. Bridges, drainage ditches, and tiling on the Slalom, Macdonald, and Sparks runs, as well

317 Unknown Author, "Radio Station CFRA," Ottawa Ski Club Yearbook 1961-62, 53. http://gvhs.ca/digital/gatineau-park/osc/1961-1962-year-book.pdf (accessed 20 February 2014).

318“'Special General Meeting," Lease of Land from the National Capital Commission, 22 June, 1964, http://gvhs.ca/digital/gatineau-park/osc/1964-06-10-NCC-lease.pdf (accessed February 11, 2013). 
as the laying of 600 bales of straw to homogenize surfaces awaiting snow, drastically altered the landscape and showed the environmental impacts of hill skiing. ${ }^{319}$

John Clifford Ski Tows, and the OSC's expansion of infrastructure and maintenance of the hills reached an industrial scale by the mid-1960s. Operators and their crews laboured during the summer, using heavy machinery, dynamite, and their bodies to work the landscape of Camp Fortune into an ideal ski sportscape. They were bound to the environment through the rocks they blasted, trees they felled, and streams they diverted. Men like John Clifford and David Midgley made a living from their work in the nature of Gatineau Park. In his contribution to William Cronon's Uncommon Ground, Richard White explored the relationship between physical work and nature, suggesting that, "Work that has changed nature has simultaneously produced much of our knowledge of nature." ${ }^{320}$ Since the first members of the OSC began clearing trails, building bridges, constructing lodges, developing alpine infrastructure, and mapping their surroundings, the physical understanding of the landscape they possessed was shaped by their work. Although he did not begin working for the OSC until 1968, Joseph Woods recalled "building trails for myself," transforming the terrain into a sports landscape that provided a desired type of embodied experience. ${ }^{321}$ The trails they built, the fruits of their labour, also determined how future visitors to the area came to know the landscape.

By 1967, the landscape of Camp Fortune was a modern skiing sportscape and included the necessary infrastructure on and off the hill. Snowmaking pipes and canons

319 Glenn Ross, "Plant Committee Selects New Food Concessionaire Recommends Changes in Lift Approaches," Ottawa Ski Club Bulletin 1968 Annual Report, (Ottawa: Ottawa Ski Club Publication, 1968), 4.

320 Richard White, ““'Are You an Environmentalist or Do you Work for a Living”: Work and Nature,” in Uncommon Ground, ed. William Cronon, (New York: W.W. Norton \& Company, 1995), 171.

321 Joseph Woods, interview by author, September 12, 2013, Chelsea, QC, digital recording. 
turned water and air into manmade snow; groomers facilitated the manicuring of the skiable surface; powerful overhead electric lighting allowed skiers the freedom to ski six evenings a week; chairlifts brought skiers to the top of four different hills in complete comfort and security; and four lodges gave skiers an interior space to socialize and talk about their experience on the slopes. John Clifford Lifts, proprietor and operator of the chairlifts, designer and developer of the slopes and snowmaking, transformed and expanded Camp Fortune to accommodate the evolving spatial needs of experiential, recreational, and elite sports cultures in one location. ${ }^{322}$ The alpine skiing community of the OSC grounded itself at Camp Fortune, and hill skiers experienced Gatineau Park from the monocultural space there.

Beginners looking to experience the sensation of skiing first hand progressed from the easier Pee Wee and Pinault hills, where they could take lessons in proper ski style from experienced instructors. After acquiring the fundamentals of control, they could explore the longer, slightly more challenging runs of Marshall, Macdonald, or Alexander, and even get a taste for the steep terrain of the Slalom Hill. The intermediate hills of Camp Fortune valley were filled with recreational skiers, families, and old-timers who enjoyed the well groomed hills at their own pace, for the love of sport and to engage with their peers. Recreational skiers benefitted from the equipment and conditions created to fulfill the needs of elite skiers, but appreciated reliability and comfort over efficiency and performance. Elite alpine racers skied the taller and steeper slopes of Skyline. Their movements, clothing, equipment, and the terrain they conquered with these things were produced for maximum efficiency. Once new technologies were tested at the highest

322 Eichberg, Body Cultures, 9. 
level, the consensus society of recreational skiers, the largest portion of the hill skiing population, adopted them into the mainstream of the sport. ${ }^{323}$ The international triumph of Anne Heggtveit validated the landscape of Camp Fortune and the racing culture of the $\mathrm{OSC}$ as a production ground for elite skiers.

The cross-country trails' sinuous and secluded nature largely protected them from heavy mechanical alterations of the landscape. Instead of changing the natural shape of the hills and installing new layers of snow to create a reproducible surface and experience, the trail network of the OSC navigated around the rocks, lakes, hills, and trees of the Kingsmere-Camp Fortune area: the landscape shaped the trails. The relationship between the trails and the Gatineau Hills was fundamentally different from that of the alpine slopes. As Bale's introduction to Sports Geography outlines, "the changing character of the sports landscape and the symbiosis between the sports environment and those who participate in it" can be seen in how the sports communities of cross-country and alpine skiing shaped Gatineau Park space. ${ }^{324}$ Alpine infrastructure at Camp Fortune was a multi-million dollar industry; it took almost all of the club's funds and allowed men like John Clifford and David Midgley to pursue careers in the ski industry. They made their livings by working in Gatineau Park. Camp Fortune also provided work for labourers, kitchen staff, lift attendants, and mechanics who made the recreational activities of skiers possible with their work.

Trail skiers imposed less intensive alterations to the landscape than the alpine industry. The Trail Riders work in Gatineau Park space was based on the sensation of adventure, physical fitness, and experiencing the outdoors; the trails they constructed

\footnotetext{
323 Eichberg, Body Cultures, 9.

324 Bale, Sports Geography, 5.
} 
reflected these feelings and followed contemporary norms established by cross-country racing. ${ }^{325}$ As in alpine skiing, elite racers like Martin Aller, who won the 1972 Canadian Ski Marathon, pushed the limits of equipment in training. Less competitive skiers like MacConaill explained how he and his fellow Trail Riders simply "found something that worked, and then forgot about it" when choosing equipment. ${ }^{326}$ They all wore similar clothing and used similar ski designs because they skied in similar conditions and in the same group. If one member of the group decided to improve the technology of their skis, using fiberglass instead of hickory based skis for example, the rest of the group would be pressured to acquire similar equipment to benefit from the new technology and not get left behind. The application of Eichberg's "trialectic" to the society of trail skiers would explain these decisions as the social pressures of a consensus society in practice. ${ }^{327}$

The Trail Riders' intimacy and knowledge of the landscape was finally validated in 1967 with the creation of the most detailed map of the Kingsmere-Camp Fortune area to date. The knowledge acquired through work and displayed on the map was a labour of love. Michael MacConaill and Allan Richens worked together with the National Research Council to recreate the physical legacy of their sport by situating the trail network in the topographical landscape. ${ }^{328}$ Original trail names, whether they represented the name of builder, the forest the trail explored, or used ironic wordplay, enshrined the human history of Charles Mortureux, George Amyot, Frank Bedard, John Clifford, Herbert

\footnotetext{
325 Joseph Woods and Michael MacConaill emphasized the influence a growing racing culture had on the westward expansion of the trial network in the 1960s and 1970s. Michael MacConaill, interview by author, November 13, 2013, Gatineau, QC, digital recording; Joseph Woods, interview by author, September 12, 2013, Chelsea, QC, digital recording.

326 Michael MacConaill, interview by author, November 13, 2013, Gatineau, QC, digital recording.

327 Eichberg, Body Cultures, 125.

328 Michael MacConaill, interview by author, November 13, 2013, Gatineau, QC, digital recording; Joseph Woods, interview by author, September 12, 2013, Chelsea, QC, digital recording.
} 
Marshall, and Joe Morin in the physical landscape of the Kingsmere-Camp Fortune ski area. The area depicted by the map extended further to the west than the 1957 map to encompass the trails developed by the reinvigorated Trail Riders. The landscape of Gatineau Park was depicted from the ground up using a layering technique that combined aerial photographs, topographic mapping, and relief shading. ${ }^{329}$ Hills, lakes, ponds, and the red lines depicting trails past and present, outlined the historical relationship between skiers and Gatineau Park space through the veins of mobility that brought humans through the area.

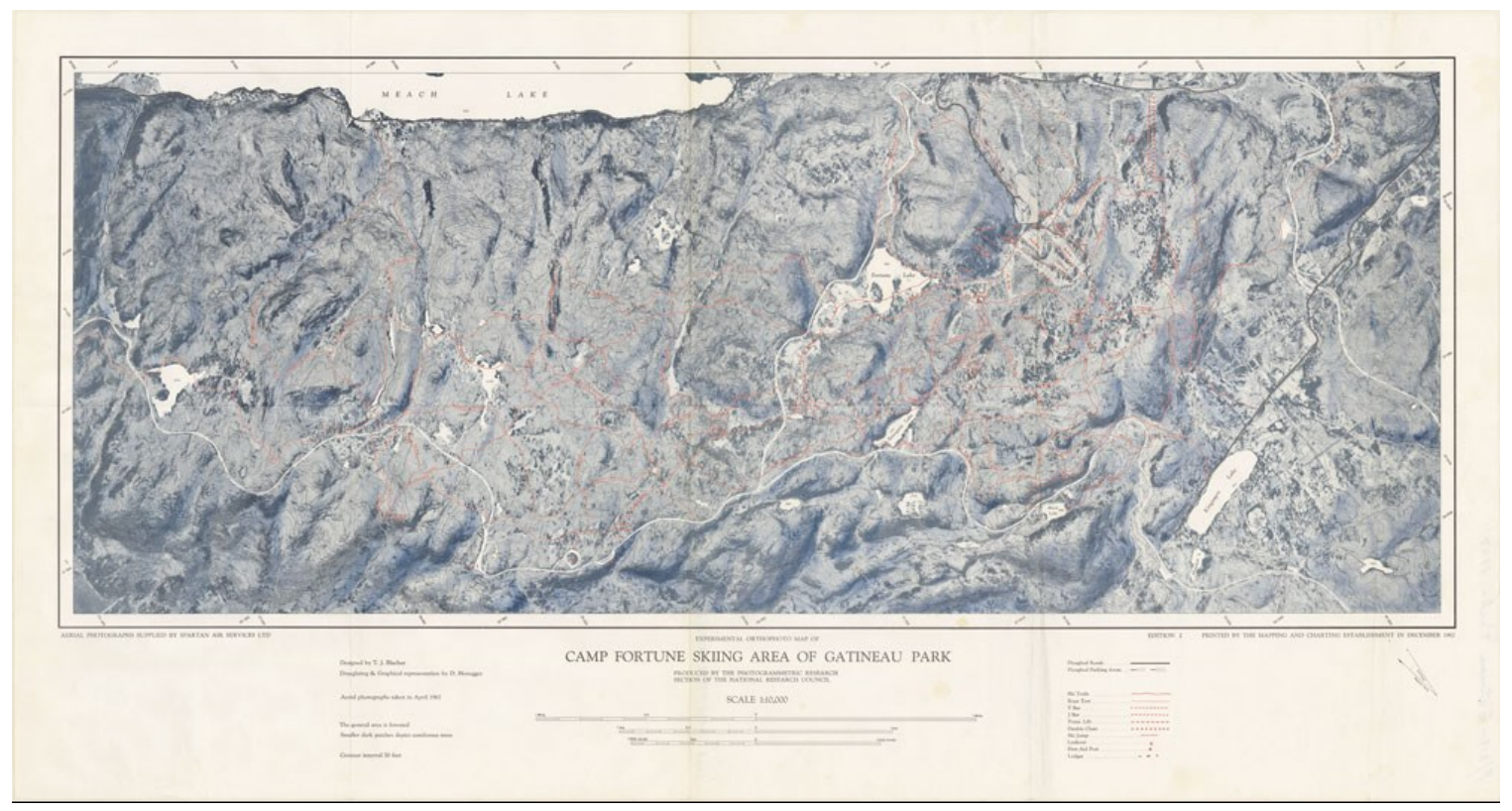

Figure 10: 1967 Orthophoto map of Camp Fortune Skiing Area of Gatineau Park. Produced by the Photogrammetric Research Section of the National Research Council.

329 Guide Gatineau, “The Making of 1967 Gatineau Park Ski Map,” (October 2010). YouTube. https://www.youtube.com/watch?v=InpSSIXScrM (accessed 14 March 2014). 


\section{Conclusion}

For most visitors to Gatineau Park today, the recreational trail network and snow covered parkways are the only way to access the forests and hills of the Kingsmere-Camp Fortune area in winter. Most of the trails are open to skiers only, as foot traffic and snowshoes damage the surface of ski trails. ${ }^{330}$ Visitors park their cars in lots numbered 1 to 19 , marked with blue signs provided by the National Capital Commission, who manage Gatineau Park. Each parking lot has a trailhead from which skiers can access over 150 kilometers of cross-country ski trails, including the wide surface of the Fortune and Champlain Parkways, which are closed to cars during winter and groomed for skiing. Although the parkways have increased the total mileage of skiable terrain available to skiers, the trail network has not developed very much since 1967, except for the creation of a biathlon course and shooting range at the western end of the Camp Fortune valley.

The NCC charges visitors for the use of the trail network, and pass checkers are posted in some parking lots on weekends, but payment is largely based on an honour system. Maps, distance markers, and educational signs present visitors with information about the trail network and to help guide skiers along. Every parking lot is equipped with a map of the entire park and its trails, lodges, and lakes. Skiers consult these maps, either in the parking lot or on the commission's website, and use them to plan their trip through the Gatineau Hills. The NCC website recommends routes and loops depending on a skier's level of ability, their style of skiing, and the desired length of their trip.

\footnotetext{
330 Because snowshoers and winter-hikers do not slide on the snow with the same speed as skiers do, their trails can be steeper, narrower, and make sharper turns. These trails are a sportscape unique to the spatial needs of foot-traffic. There are walking and snowshoeing trails emanating from parking lot 6 at the Mackenzie King Estate, from the Gatineau Park Visitor's Centre in Old Chelsea, and from parking lot 13 on Meech Lake.
} 
Cross-country ski trails on the NCC map are categorized according to difficulty and the style of skiing recommended for each trail. Although the subdisciplines of trail skiing used today were not fully formed during the period explored by this thesis, the three categories identified by the NCC trail map are remarkably "trialectic" in their stratification of trails and the skiers who use them. Trails are designated as either shared (classic and skate), classic only, or back-country. ${ }^{331}$ The style of "skate-skiing" did not exist as a discipline in the period explored by this work, but it has become increasingly popular among the fitness and achievement communities of cross-country skiing. Skateskiers borrow extensively from the international racing community in terms of equipment and style. They use lightweight skis, long poles, and generally wear tight-fitting athletic clothing made from spandex and lycra. This style is adopted by fitness enthusiasts looking to push their cardiovascular limits in an outdoor environment, and requires a great deal of physical coordination. Skate skiers' motion involves an elongated stride and weight transfer from side to side resembling that of speed skaters on ice, but with the mechanical advantage of long poles used to maintain forward momentum. The lateral motion requires a wide, groomed surface and makes skate skiing unsuitable for the narrower trails in the park; skate-skiers generally use the parkways, which became more popular as skiing routes following 1967. Skate-skiing's spatial requirements have caused the widening of several trails on the network in order to accommodate them, and the large grooming machines required to produce the necessary ski surface. In summer, a trail able to support skate-skiing is more akin to a road than a trail.

331 Bale, Sports Geography, 9. Bale's “trialectic”s emphasis on each sport scenario's relationship with space helps explain the categorization of the trails. CC Trail Map, available at http://www.nccccn.gc.ca/sites/default/files/pubs/11055_gp_wintertrail_map_4.pdf. ACCESS DATE 
The "classic" style of skiing is by far the most popular and allows skiers the most freedom in their movement through the trail network, as their equipment and technique do not restrict them from any of the ski trails. Classic skiing equipment ranges greatly from narrow, lightweight racing skis, to wide, stable "backcountry" skis; some even have metal-edges. The stride of the classic skier is similar to the practice used for decades that involves a weight transfer from one foot to the other while alternating pole pushes maintain forward progress and balance. Shared and classic-only trails are machine groomed with parallel tracks set by the groomer on either side of the trail in which skiers slide; like drivers on a road, skiers keep to the right to avoid collisions. Classic skiing involves members from all three categories of the "trialectic." The movement of classic skiing requires less skill and coordination than skate-skiing, making it more accessible for those looking to experience new forms of body culture. Serious racers generally compete in both skate and classic style races, so members of the achievement sport scenario of the "trialectic" use the groomed classic trails to train. Most skiers in Gatineau Park fall into the fitness sport scenario of the "trailectic," using classic skiing to improve their fitness in the sportscape of purpose built cross-country ski trails.

Skiers who choose the "backcountry" trails are no different in appearance or equipment to most classic skiers, although they may have slightly wider skis or sturdier boots, noticeable only to astute observers. In Gatineau Park, dedicated backcountry skiers are comparatively rare, and there is no competitive level of the sport, so participants fall within either the fitness or experiential scenarios of the "trialectic." More than the other disciplines, the trails are what define the backcountry style, as the equipment is less important, and classic style skis generally suffice. Backcountry trails are not groomed, 
they have steep climbs and descents, they cross over frozen lakes, follow the edges of cliffs, and do not attract the same numbers as the more accessible trails. ${ }^{332}$ In the Kingsmere-Camp Fortune area, the backcountry trails were mostly built in the 1920s by the Night Riders, prior to the clearing of the Joe Morin Slalom run at Camp Fortune that acted as a springboard for the popularization of hill skiing in the area.

Along the groomed trails, visitors encounter a number of signs provided by the NCC, which tell the story of human, animal, and plant life in Gatineau Park. Keen eyed patrons may notice recurring mentions to the Ottawa Ski Club and the role its members played in the development of the trail network. The importance of the OSC in shaping Gatineau Park recreational space, however, is generally understated. ${ }^{333}$ Although informative signs appear throughout the park, backcountry trails in the Kingsmere-Camp Fortune area, numbered $8,11,17$, and 23 , lack any indication of their history or importance to the development of the trail network. Skiers in the park today are unaware that the Highland (8), Merry-Go-Round (11), Frank's (17), and Nature (23) trails are among the oldest ski trails in Gatineau Park, some over 90 years old; they seem out of place in a predominantly groomed network. These trails were designed for a type of skiing that predates the separation of the sport into the broad categories of alpine and cross-country, and they are an experiential archive of skiing before the fundamental division in skisport. The only backcountry trail with a sign on it is the Western Trail (9). The sign mentions the OSC's role in clearing the original Western Trail in 1930 when a

332 Between November 29 $9^{\text {th }}, 2013$, and March $1^{\text {st }}, 2014$, I skied 44 trips in Gatineau Park, using three different sets of equipment, skate, classic, and backcountry. My usual starting point for backcountry and classic skiing was parking lot 7 at Kingsmere, for skate skiing I usually left from parking lot 5, also on Kingsmere road. Other starting points were P1, 2, and 3 in the southern park for skate and classic; P6 at Mackenzie King Estate for classic; P8 at Chelsea for skate; and P10, 11, 12, 17, and 19 for classic.

333 In the Kingsmere-Camp Fortune area, there are signs on Ridge Road (trail 1), where it intersects with Fortune Lane (trail 4), 
conflict with farmers in the area arose, but the NCC's signs do not address the genesis of the trail network and skiing in Gatineau Park.

Alpine skiers visiting the ski hills at Camp Fortune may not be aware that the privately owned and operated ski area is on Gatineau Park land, under lease from the NCC. Although the ski hills have not undergone any considerable expansion projects since the Meech Tee-Bar and two new intermediate runs were built in 1964, the chairlifts, snowmaking, and amenities for skiers, many of which built under the guidance of John Clifford, have continued to modernize and crowds continue to pay a fee to line up for the chairlifts to access the alpine terrain. In 1971, the Ottawa Ski Club bought out John Clifford for $\$ 500,000$, and took possession of the lifts and snowmaking equipment on the hill; at the time, the private club had reached its peak membership of 15,000 skiers. ${ }^{334}$

When Jamie Rosewarne moved to Ottawa from Muskoka in 1976, to assume the role of head coach at the Ski School at Camp Fortune, he was awestruck by the low price of skiing in the national capital region. "We were charging peanuts for access to recreational skiing, whether it be lessons or competitive programs." ${ }^{335}$ This was at a time when Camp Fortune competed with other local ski hills at Edelweiss, Vorlage, and Mont Cascades, and the Gatineau Park trail network competed against a smaller, better maintained cross-country ski centre at Nakkertok. ${ }^{336}$ Rising operational costs, a complicated executive structure, and years of accumulated debts accrued from constant expansion resulted in the OSC's bankruptcy in 1989. "When it went bankrupt, that was the opportunity for the NCC to seize the last [major] parcel of land that was under private

334 Elliott Kaufmann and John A. Stevens, White Gold: The John Clifford Story (Renfrew: General Store Publishing House, 1993), 32.

335 Jamie Rosewarne, interview by author, September 30, 2013, Ottawa, ON, digital recording.

336 Martin Aller explained that this was one of the reasons he and his family began skiing at Nakkertok, and visited the Gatineau Hills less frequently following its opening. 
ownership, in the park. ${ }^{{ }^{3} 37}$ As general manager of Camp Fortune at the time of the OSC's bankruptcy, Rosewarne negotiated with the NCC for the future of the ski hill, and made clear his understanding of the area's central role in Canada's ski history.

One of the things, having had the exposure I did to the ski area, to the multitude of contributors to Canadian ski development, the Shaun Fripps, the John Hannas, the John Cliffords, the Art and Andy Tommys. It gave me the sense of how important this region was, of how important this asset was, that we had to maintain some things at perpetuity. One of those things was the right to access all of those competitive structures. So, imbedded in the NCC's contract, at infinitum, is that there has to be access for those interest groups, always; for cross-country, alpine, freestyle, jumping, biathlon. That's a legacy the ski area created in the first place, and the ski club, the environment of the park. It was really important for me that that didn't disappear. I didn't want to see that lost in our heritage in this region. ${ }^{338}$

Today, the lifts, lodges, and equipment are owned and operated by the Suderman family, and Camp Fortune remains the closest hill-skiing facility to Ottawa. Ski instruction for beginners, several intermediate runs, a racing program, and the relatively new development of terrain parks, allow Camp Fortune to cater to all levels of skiers. ${ }^{339}$

This thesis has shown how skiing in the Gatineau Hills became decisively split into alpine and cross-country disciplines, each with their own spatial requirements, and each with a number of sub-disciplines. Today, travelling from cross-country trails to liftaccess hills and back again would be an anachronistic transgression of the bounded spaces produced by almost a century of skiing. When the backcountry trails on the contemporary NCC Winter Trail Map were built, mostly in the 1920s, no such division between hills and trails existed. The Kingsmere-Camp Fortune area was a permeable

337 Jamie Rosewarne, interview by author, September 30, 2013, Ottawa, ON, digital recording. Today, about $2 \%$ of land in Gatineau Park is privately owned.

338 Jamie Rosewarne, interview by author, September 30, 2013, Ottawa, ON, digital recording.

339 Terrain parks are areas on a ski hill devoted to the discipline of slopestyle snowboarding and skiing. These include large jumps, half-pipes, and other obstacles like rails and boxes that allow skiers and snowboarders to perform tricks. 
space of skiing in those days, with a handful of lodges providing social spaces for members of the OSC.

The trail network had two important eras of development in the time of Joe Morin's Night Riders of the Canyon in 1923, and the days of MacConaill and the Trail Riders of the 1950s and 60s. The trails they built reflected the ski practices of their times. Morin and his contemporaries sought the hills of Camp Fortune in an era before alpine skiing existed as a separate discipline and before Gatineau Park existed. Skiing in this period was simply skiing. MacConaill and the Trail Riders, on the other hand, helped reinvigorate the trails left behind by skiers of the pre-tow age, neglected by a weakened trail community of the early 1950s. Once the Kingsmere-Camp Fortune network was restored, the Trail Riders looked west and expanded the network along the old Western Trail, which had been all but abandoned. Trails like the Burma Road (3), Pipe Dream (20), Walters (18), and Huron (21) were the result of renewed interest in cross-country skiing in the 1960s that involved a larger racing program and increased trail construction by the Trail Riders. Trails built in this second wave were less precipitous than those of the Night Riders, and took into consideration the needs of cross-country racing. The interactions between people and the Kingsmere-Camp Fortune section of Gatineau Park are best understood by examining the recreational ski trails produced by the sports community as an experiential archive where body cultures' interaction with the landscape gave the space its meaning.

Today, the NCC explains its role in providing visitors with a history of the park as one to "protect and interpret those heritage resources that promote public understanding and appreciation of the history, evolution, and role of Gatineau Park within the 
Capital." ${ }^{\prime 34}$ The NCC's recognition of the park's human history is relatively new. The information made available to visitors on the trails built by members of the OSC, many before the formal creation of Gatineau Park, understates the role played by the club and misses an opportunity to situate the area within the wider context of skiing. Home to the largest club in the world in the 1950s and 60s, the recreational trails in the KingsmereFortune area are part of a larger conversation of ski history.

An example of a trailside sign on the Huron Trail (Sentier Huron, or Trail 3), one of the few ski trails today with a name, presents visitors with the following information: "The lookouts on the Gatineau Parkway commemorate the passage of European explorers up the Ottawa River. The lookout, lodge and trail bearing the name "Huron" were named for their Indian guides and trading partners." ${ }^{\prime 34}$ The sign is an example of the NCC's attempt to present visitors with a human history of Gatineau Park. This particular sign, however, fails to adequately recognize important aspects of the trail's history. The name of the trail and information on the sign overwrite the ski history of the Burma Road, the original name of the ski trail, given to it by the skiers who cleared it. In fact, the name Huron came from a trail west of the Trail 3: the original Huron Trail is now Trail 21. The information on the sign and trail name commemorate European colonialism by acknowledging aboriginal presence in the form of guides and trading partners only. Gatineau Park is located on unceded Algonkin territory, and the sign erases Algonkin presence in the area. There is also no mention of the history of farming in the area that left sections of cleared forest and old logging trails upon which the modern ski network

340 NCC, "Heritage and Culture in Gatineau Park," NCC website, http://www.ncc-ccn.gc.ca/places-tovisit/gatineau-park/heritage-culture-gatineau-park (accessed 3 March 2014).

341 NCC, sign on the side of Huron Trail just west of the Fortune Parkway. Photographed by author, February 11, 2014. 
was founded. The sign in question is located between the Ramparts lookout and the Fortune Parkway, the very section of trail Michael MacConaill recalled clearing as the Burma Road in 1960 as part of the cross-country racing loop and general westward expansion of the trail network. ${ }^{342}$

Joseph Woods recalled working on the Burma Road in the mid 1970s, modifying it to accommodate new mechanical trail grooming equipment. An Alpine snowmobile, with one ski in the front and two tracks, pulled a grooming tool behind it that compressed the snow and left two parallel grooves in its wake, setting a track for skiers. "I recut and regraded the Burma Road from Huron, so that it could be track-set." Woods' work on the trail was also a reflection of his own interpretation of how his body should interact with the landscape through the medium of skiing. "You can feel the rhythm and the momentum I tried to make. I arranged the downhills so that your momentum would take you up a lot of the uphills. I cut it according to how I liked to ski it." ${ }^{\text {"43 }}$ Today, Trail 3 remains one of the most popular groomed trails in the park among skate and classic skiers because of the feeling of momentum Woods' incorporated into his design. Although the name has been removed from current maps, and the trailside sign presents a history unrelated to the trail itself, the Burma Road name remains part of the vernacular for many skiers in Gatineau Park to this day. ${ }^{344}$

The story of the Gatineau Hills in the context of the national capital region began when politicians, civil servants, and merchants, mostly from Ottawa, began looking to the hills for the positive experience of enjoying the outdoors. Very soon, a group of dedicated

\footnotetext{
342 Michael MacConaill, interview by author, November 13, 2013, Gatineau, QC, digital recording. 343 Joseph Woods, interview by author, September 12, 2013, Chelsea, QC, digital recording.

344 In conversations with skiers in Keogan and Western Lodges, the name Burma was one of the only one people used.
} 
skiers began transforming industrial roads and farmers' fields into a winter playground and training area for the sport of skiing, while wealthy cottagers purchased land on the shores of Meech and Kingsmere Lakes. Long before the federal government took action towards creating a wilderness park in the Gatineau Hills, the Ottawa Ski Club brought thousands of people in contact with the landscape and started purchasing land to protect the trails they built in the area. This history of skiing in the Kingsmere-Camp Fortune area should encourage people to think about Gatineau Park as a space that was once Canada's national capital region of skiing.

This work is situated in the larger conversation of environmental, geographical, and sports histories. Emphasis here is placed on how skiers understood the KingsmereCamp Fortune area of Gatineau Park from 1910 until 1967, and how changes in ski technology, accessibility to ski facilities, and the division between cross-country and alpine skiing shaped space according to the spatial requirements of their sport. Henning Eichberg's "trialectic" and John Bale's adaptation of it, as well as his concept of monocultural sportscapes, act as a theoretical framework for this study of the relationship between skiers and space. Andrew Denning's recently published article in Environmental History applies Bale's concept of monocultural sportscape to explain the development of ski resorts in the postwar Alps. Denning's work allowed this thesis to go one step further, and explore the parallel sportscapes of cross-country and alpine skiing built in the Gatineau Hills. There remains, however, much work to be done on Gatineau Park.

This work's emphasis on sports, space, and geography leaves a gap for future discussions of politics, gender, masculinity, race, class, and perhaps most importantly, the 
linguistic tensions between Anglophones and Francophones in the area. ${ }^{345}$ There is certainly work to be done on the business of skiing at Camp Fortune, especially in comparison to other ski hills that emerged in the region at Vorlage, Mont Cascade, Edelweiss, and Mont Sainte Marie, and a history of Gatineau Park's automobile parkways would strengthen the discussion of space and mobility. This thesis was very much written from a skier's perspective, and approaches from outside this scope would strengthen the literature on Gatineau Park.

In closing, this project has left me with the impression that histories of sport are a valuable way of understanding the past. For many, sport is the most important aspect of a person's identity. The interviewees for this thesis were all skiers, and the OSC Yearbooks are an archive of a dedicated ski community who derived group identity and structured their lives around skiing. Whether training for a race, exploring the trail network, spending a day on the slopes of Camp Fortune, voluntarily clearing a trail in fall, or simply enjoying the views from the Eardley Escarpment, skiers devoted most of their free time to the pursuit of their passion for sliding on snow. Gatineau Park space was shaped from the ground up by the largest ski club in the world, and it should be remembered as such.

345 Interviewees were asked about linguistic tensions, but discussions of the subject were not pushed very far by the researcher. 
ethics@carleton.ca

\section{Ethics Clearance Form}

This is to certify that the Carleton University Research Ethics Board has examined the application for ethical clearance. The REB found the research project to meet appropriate ethical standards as outlined in the Tri-Council Policy Statement: Ethical Conduct for Research Involving Humans, $2^{\text {nd }}$ edition and, the Carleton University Policies and Procedures for the Ethical Conduct of Research.

$\square$ New clearance

$X$ Renewal of original clearance

January 2013

Date of renewal

Researchers

Department

Supervisor

Project number

Title of project

Clearance expires:
5 September 2013

Quinn Lanzon, Master's student

History

Prof. Joanna Dean, History

13-0924

Gatineau Park Recreational Trail Network: A History

Original date of clearance: 29

31 May 2014

\section{All researchers are governed by the following conditions:}

Annual Status Report: You are required to submit an Annual Status Report to either renew clearance or close the file. Failure to submit the Annual Status Report will result in the immediate suspension of the project. Funded projects will have accounts suspended until the report is submitted and approved. 
Changes to the project: Any changes to the project must be submitted to the Carleton University Research Ethics Board for approval. All changes must be approved prior to the continuance of the research.

Adverse events: Should any participant suffer adversely from their participation in the project you are required to report the matter to the Carleton University Research Ethics Board. You must submit a written record of the event and indicate what steps you have taken to resolve the situation.

Suspension or termination of clearance: Failure to conduct the research in accordance with the principles of the Tri-Council Policy Statement: Ethical Conduct for Research Involving Humans, $2^{\text {nd }}$ edition and the Carleton University Policies and Procedures for the Ethical Conduct of Research may result in the suspension or termination of the research project.

Andy Adler, Chair

Carleton University Research Ethics Board
Louise Heslop, Vice-Chair

Carleton University Research Ethics Board 


\section{Bibliography}

Oral Interviews:

Aller, Ann. Interview by author, November 16, 2013, Ottawa, ON, digital recording. Gatineau Valley Historical Society.

Aller, Martin. Interview by author, November 16, 2013, Ottawa, ON, digital recording. Gatineau Valley Historical Society.

Dagenais, Mark. Interview by author, September 17, 2013, Chelsea, QC, digital recording. Gatineau Valley Historical Society.

MacConaill, Michael. Interview by author, November 13, 2013, Gatineau, QC, digital recording. Gatineau Valley Historical Society.

Midgley, Arnold. Interview by author, September 25, 2013, Ottawa, ON, digital recording. Gatineau Valley Historical Society.

Midgley, David. Interview by author, November 12, 2013, Gatineau, QC, digital recording. Gatineau Valley Historical Society.

Rosewarne, Jamie. Interview by author, September 30, Ottawa, ON, digital recording. Gatineau Valley Historical Society.

Woods, Joseph. Interview by author, September 12, 2013, Chelsea, QC, digital recording. Gatineau Valley Historical Society.

\section{Primary Sources:}

Ottawa Ski Club Newsletters and Yearbooks 1921-1967 
$\underline{\text { Published Sources: }}$

“Cliffside Ski Club.” Canadian Ski Annual 1925-26, Accessed February 11, 2014. http://www.skimuseum.ca/documents/annuals/1925-26 pt13 pg29-31.pdf.

Graham, John. "The Cliffside Ski Club of Ottawa." Canadian Ski Annual 1923-24, 1924. Accessed February 11, 2014. http://www.skimuseum.ca/documents/annuals/192324 pt16 pg34-39.pdf.

Gréber, Jacques. Plan for the National Capital General Report, (Ottawa: Federal District Commission, 1950), 104. Accessed February 11, 2014.

https://qshare.queensu.ca/Users01/gordond/planningcanadascapital/greber1950/ope nspace.htm.

King, William Lyon Mackenzie. "The Diaries of Prime Minister William Lyon Mackenzie King," (April 26, 1926), 116. Accessed February 112014. https://www.collectionscanada.gc.ca/databases/king/001059-119.02e.php?\&page id nbr $=9840 \&$ interval $=20 \& \&$ PHPSESSID $=5$ df1pekolkfts4indi 1638 $\underline{\mathrm{mb} 36}$.

King, William Lyon Mackenzie. "The Diaries of Prime Minister William Lyon Mackenzie King,” (September 20, 1933), 263. Accessed February 11, 2014. https://www.collectionscanada.gc.ca/databases/king/001059-119.02e.php?\&page id nbr=14486\&interval $=20 \& \&$ PHPSESSID $=$ req3 eoice06evalougrvg ukel2.

King, William Lyon Mackenzie. "The Diaries of Prime Minister William Lyon Mackenzie King," (December 20, 1937), 1148. Accessed February 11, 2014. https://www.collectionscanada.gc.ca/databases/king/001059-119.02e.php?\&page id nbr=18590\&interval=20\&\&PHPSESSID=9og8tru5dmdgiutnbe0a rgrhr3.

Lanctot, R. Gustave. "History of the National Capital," Plan For the National Capital General Report, (Ottawa: Federal District Commission, 1950), 42. Accessed February 11, 2014.

https://qshare.queensu.ca/Users01/gordond/planningcanadascapital/greber1950/hist ory.htm.

Murray, Jean-Paul. "Gatineau Park's Forgotten Founder," The Ottawa Citizen, December 8, 2003. Accessed February 13, 2014. http://search.proquest.com/docview/240707536?accountid=9894.

National Capital Commission "Wattsford Lookout," National Capital Commission trail sign at the intersection of Ridge Road and the Penguin hill, near the beginning of the Skyline trail. Sign photographed by author February 10, 2014. 
The New Woodlands Preservation League, "Bill S-210: A Compromise Designed to Protect Gatineau Park," Brief submitted to the Senate Standing Committee on Energy, the Environment and Natural Resources (March 14 2007).

\section{Unpublished Sources:}

Cahill, Harmon. Unpublished Diary. 1956-1968. In the possession of Mark Dagenais.

\section{$\underline{\text { Secondary Sources: }}$}

Andrews, J. David. Gatineau Park: An Intimate Portrait. Ottawa: Dynamic Light Productions, 1994.

Ballantyne, Bruce. "Stations of the Gatineau Valley Railway," Up the Gatineau! Vol. 24, (1998). Accessed February 11, 2014. http://www.gvhs.ca/publications/utgastations.html.

Bale, John. Sports Geography. $2^{\text {nd }}$ Edition. London: Routledge, 2003.

Campbell, Claire. A Century of Park Canada, 1911-2011. Calgary: Univeristy of Calgary Press, 2011.

Childers, Michael W. Colorado Powder Keg: Ski Resorts and the Environmental Movement. Lawrence: University Press of Kansas, 2012.

Coleman, Annie Gilbert. Ski Style: Sport and Culture in the Rockies. Lawrence: University Press of Kansas, 2004.

Eichberg, Henning. Body Cultures: Essays on sport, space and identity. Edited by John Bale and Chris Philo. London: Routledge, 1998.

Filion, Michele and Serge Gagnon. The Creation and Early Development of Gatineau Park. NCC: Ottawa, 2004.

Fletcher, Katherine. Historical Walks: The Gatineau Park Story. $3^{\text {rd }}$ edition. Marhkam: Fitzhenry \& Whiteside Limited, 2004.

Graham, Shawn. "The Mines of Gatineau Park.” The Gatineau Park Chronicle (2007). Gatineau Valley Historical Society: 2007. Accessed February 11, 2014. http://gvhs.ca/digital/gatineau-park/chronicles/mines.html. 
Hessel, Peter. The Algonkin Nation: The Original People of the Ottawa Valley. Arnprior: Kichesippi Books, 1993.

Hoffman, Alice M., and Howard S. Hoffman. "Memory and Theory: Personal and Social," Handbook of Oral History, eds. Charlton, Thomas L., Myers, Lois E., and Sharpless, Rebecca. Oxford: AltaMira Press, 2006.

Kaufmann, Elliott, and John A. Stevens. White Gold: The John Clifford Story. Burnstown: General Store Publishing House, 1993.

Marshall, Herbert. History of the Ottawa Ski Club. Ottawa: Self-Published, 1973.

Messier, Dennis. "Save the Hills!" The Gatineau Park Chronicle 2007. Ottawa: National Capital Commission, 2007. Accessed February 11, 2014. http://gvhs.ca/digital/gatineau-park/chronicles/save.html

Pickles, John. A History of Spaces: Cartographic reason, mapping, and the geo-coded world. London and New York: Routledge, 2004.

Poulter, Gillian. Becoming Native in a Foreign Land: Sport, Visual Culture, \& Identity in Montreal 1840-85. Vancouver: UBC Press, 2009.

Richens, Allan. "Beamish Hill and Beyond.” Up The Gatineau! 34, 2008. Accessed February 11, 2014. http://www.gvhs.ca/publications/utga-beamish-hill.html

Rothman, Hal. Devil's Bargains: Tourism in the Twentieth Century American West. Lawrence: University Press of Kansas, 1998.

Scott, James C. Seeing Like a State: How Certain Schemes to Improve the Human Condition Have Failed. London: Yale University Press, 1998.

Stoddart, Mark C. Making Meaning out of Mountains: The Political Ecology of Skiing. Vancouver: UBC Press, 2012.

Stroud, Ellen. Nature Next Door: Cities and Trees in the American Northeast. Seattle: University of Washington Press, 2012.

Taylor, John H. Ottawa: An Illustrated History. Toronto: Lorimer, 1986.

White, Richard. ““"Are You an Environmentalist or Do you Work for a Living”: Work and Nature." In Uncommon Ground, edited by William Cronon, 171-185. New York: W.W. Norton \& Company, 1995.

White, Richard. The Organic Machine: The Remaking of the Columbia River. New York: Hill and Wang, 1995. 
Articles:

Allen, John B. "The Modernization of the Skisport: Ishpeming's Contribution to American Skiing." Michigan Historical Review, Vol. 16, No. 1 (Spring, 1990), 120 .

Coleman, Annie Gilbert. "The Unbearable Whiteness of Skiing." Pacific Historical Review, Vol. 65, No. 4, (Nov., 1996), 583-614.

Denning, Andrew. "From Sublime Landscapes to 'White Gold': How Skiing Transformed the Alps after 1930.” Environmental History 19 (January 2014): 78108.

Duffy, Dennis. "Love Among the Ruins: The King of Kingsmere." American Review of Canadian Studies, Vol. 37, issue 3, (October 2007), 358-369.

Klingle, Matthew W. "Spaces of Consumption in Environmental History," History and Theory, Vol. 42, No. 4 (December 2003), 94-110.

Richey, Duke. "The Aspenization of Telluride: Coming of Age and Mythologizing Change in Ski Country, 1945-1985." Pacific Historical Review Vol. 79, No. 2 (May 2010), 231-264.

Rothman, Hal. " 'Powder Aplenty for Native and Guest Alike': Steamboat Springs, Corporate Control, and the Changing Meaning of Home," Montana: The Magazine of Western History, Vol. 48, No. 4 (Winter, 1998), 2-17.

Taylor, John. “Ottawa: The City as Conglomerate.” Urban History Review, Vol. 4, issue 1, (Jun 1, 1975), 36-37.

Yochim, Michael J. "Snow Machines in the Garden: The History of Snowmobiles in Glacier and Yellowstone National Parks," The Magazine of Western History, Vol. 3, No. 53 (2003), 2-15.

Theses and Dissertations:

Apostle, Alisa Catherine. "The View from the Hill: National Park Culture and Gatineau Park 1920-1960.” MA thesis, Queen's University, 1997.

\section{Internet Sources:}

Guide Gatineau. "Keogan Lodge and the Rise and Fall of the Cliffside Ski Club." (February 2011). YouTube. http://www.youtube.com/watch?v=yN9YpKm2RR4 (accessed 11 February 2014). 
Guide Gatineau. "The Making of 1967 Gatineau Park Ski Map,” (October 2010). YouTube. https://www.youtube.com/watch?v=InpSSIXScrM (accessed 14 March 2014).

National Capital Commission. "History of the Park." Accessed February 11, 2014. www.ncc-ccn.gc.ca/places-to-visit/gatineau-park/history-of-park. 